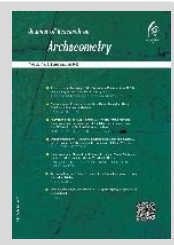

\title{
The Oldest Use of Tile in Architectural Decorations of the Islamic Period of Iran and Recognition of Combined Fractured Pieces of Glazed Pottery and Plaster-Brick Decorations Technique in Khajeh Atabak Kerman
}

\author{
Yaser Hamzavi* \\ Assistant Professor, Faculty of Applied Arts, Tabriz Islamic Art University, Tabriz, IRAN
}

Received: 05/05/2019

Accepted: 29/06/2019

\begin{abstract}
The companion of different materials in architectural decorations of Iran, during the Islamic era, in many cases has opened up new art styles and techniques and changed the aesthetic look of the cultures that carry this phenomenon. The accompaniment of brick, plaster and glaze decorations is one of the fascinating changes in the history of art of Iranian architectural decorations that its history of invention has remained somewhat obscure. Meanwhile, the initial idea of using tiles in the decorations of Iranian architecture in the Islamic era remains largely unknown. Tile is a type of architectural decoration that may be originated from ancient Iran, and therefore, little information is available about the manufacturing and execution techniques and specimens of tile works from the early centuries of the Islamic era. This aim of this work was to distinguish between the tile and the glazed-brick. From the view-point of the researcher, when the thickness of the glazed-ceramic exceeds from its width, the work becomes glazed-brick, while the width of the glazed-ceramic become greater than its thickness, it will be a tile. The main purpose of this research was to obtain the information on the oldest tiles of the Islamic period in Iran, which could be found as the glazedceramic in the architectural design Khajeh Atabak in Kerman. In order to achieve the aims of this research, the study of written sources and the field studies were carried out simultaneously, to characterize the tile works in Iranian architectural decorations, especially at the tomb of Khajeh Atabak in Kerman. On the basis of the results obtained, it could be said that unfortunately from the Islamic period in Iran till the 11th century AD., no dated tiles have been left. Many of the tiles with no written date on them have been dated by researchers regardless the manufacturing technology, and only based on the tiles appearance and archaeological characteristics. These dating studies have not been performed based on the laboratory studies and they were actually done with speculation, so are not scientifically acceptable. For example, for decades it was thought that the oldest tiles in Iranian architecture belong to the Qazvin Jame-Mosque, while as a result of field studies realized in this research, it was found that there is no antique tile in this monument, where the color of the painting was mistakenly recognized as tile. Donald Wilber reported this error for the first time, and over the several decades, all the researchers repeated the same error without careful scrutiny. Anyway, the tile samples of five monuments with a collection of tiles or with one single tile were identified as the oldest tiles of the Islamic period in Iran. One of the main results of this research is to identify the use of fractured pieces of glazed pottery in architectural decorations, where some researchers have identified these works as the tiles. In these cases, both sides of the pieces of potteries have glaze and the body is very thin and delicate along with the arches and curves. Moreover, in some cases the edges of the pottery container can also be seen. Achieving this result reinforces this hypothesis that using the broken pottery container may have formed the first idea for tiles construction.
\end{abstract}

Keywords: Architectural Decoration, Tile, Glazed Pottery, Seljuk Period, Khajeh Atabak

*Corresponding author: y.hamzavi@tabriziau.ac.ir 


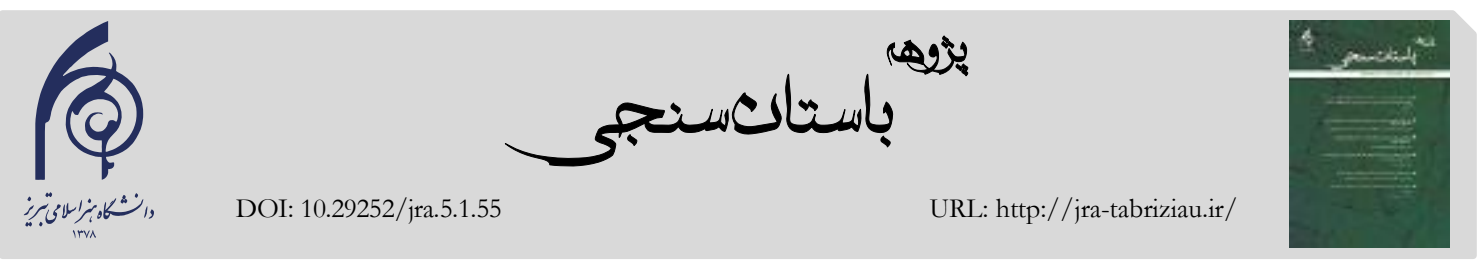

مقالم يَّوهشَى

\section{قديمى ترين كاربرد (اكاشى) در آرايههاي معمارى دورهُ اسلامى ايران}

و فنشناسى آرايهُ تلفيقى قطعات ظروف سفالى لعابدار و تَج-آجر در بقعهُ خواجه اتابك كرمان

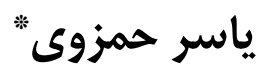

استاديار، دانشكدة هنرهاى كاربردى، دانشعاه هنر اسلامى تبريز، تبريز، ايران

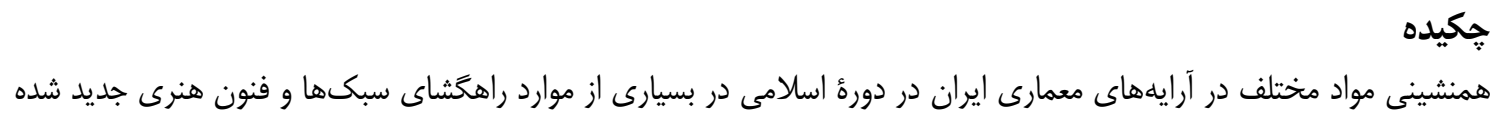

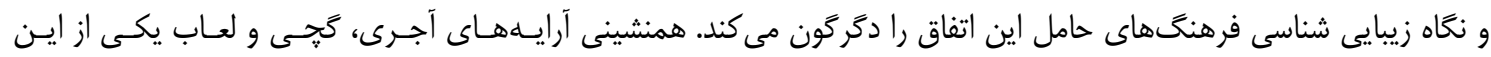

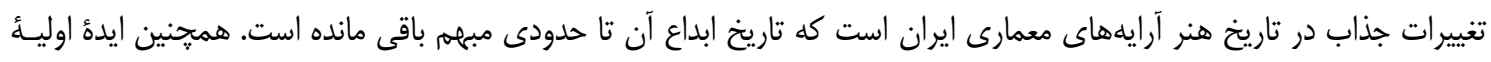

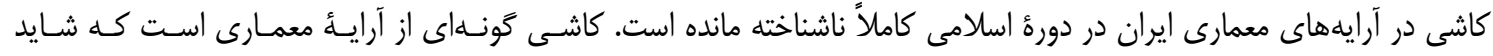

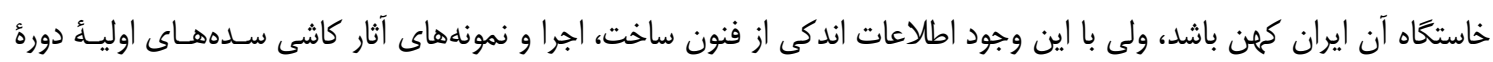

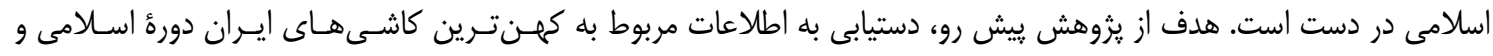

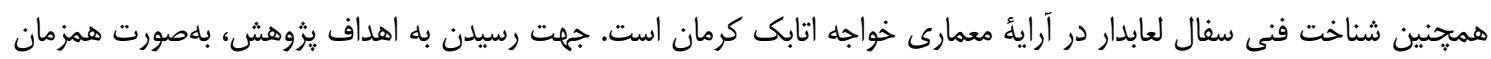

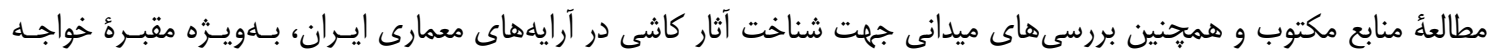

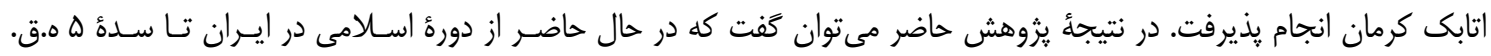

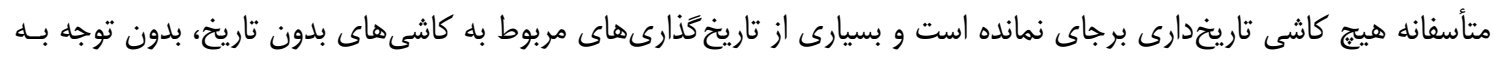

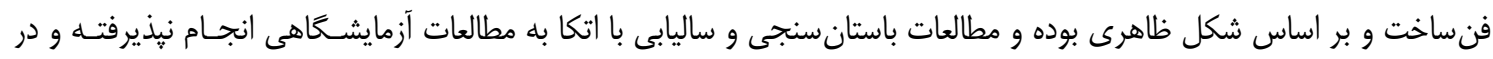

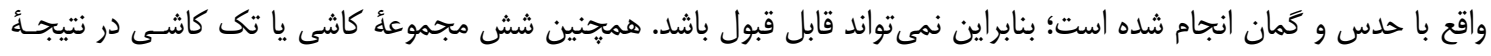

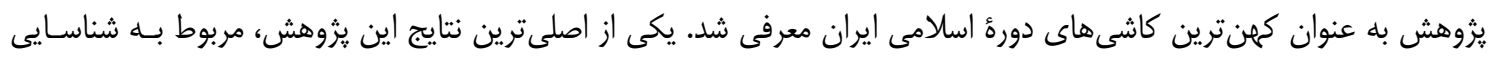

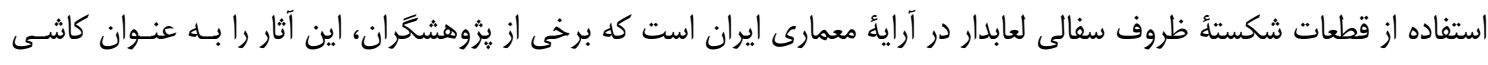

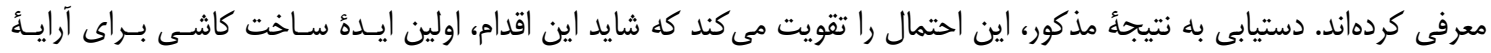
معمارى را شكل داده باشد.

وازَّان كليدى: آرايههاى معمارى، كاشى، ظروف سفالى لعابدار، دوره سلجوقى، خواجه اتابك

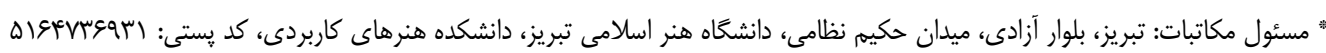

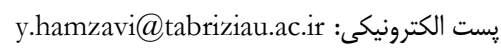
Creative Commons Attribution License به مجله اجازه مىدهد مقاله حاب شده را با ديكران به اشتراك بخذارد منوط بر اينكه حقوق مؤلف اثر حفظ و به انتشار اوليه مقاله در اين مجله اشاره شود. 


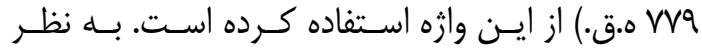

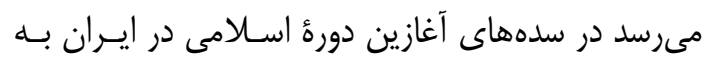

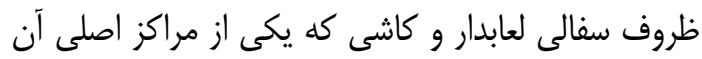

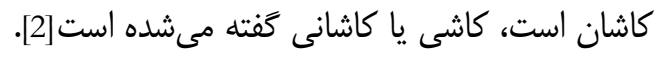

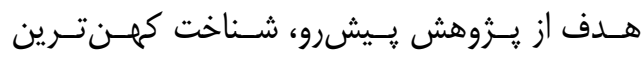

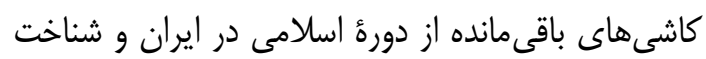

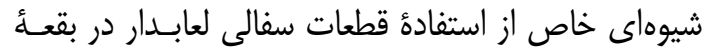

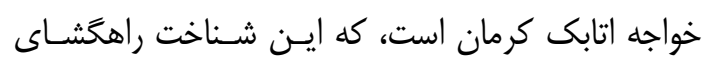
برخى از مشكلات و سوالاتى خواهد بود كه تا كنـون در إنها

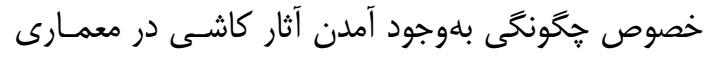

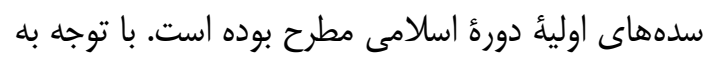

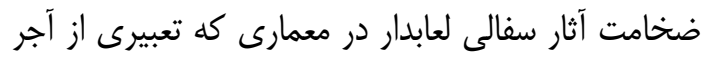

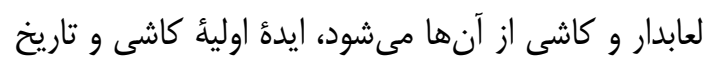

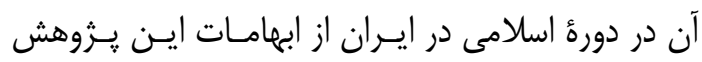

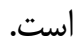

در اين مقاله ابتدا مرورى بر شـناخت قـديمىتـرين

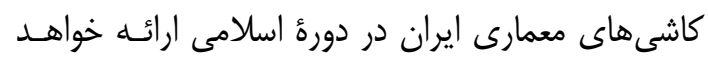

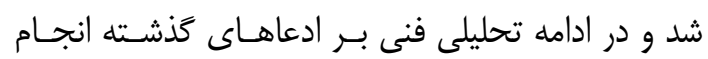

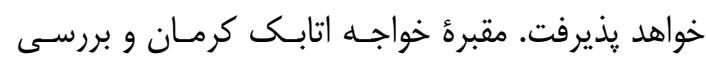

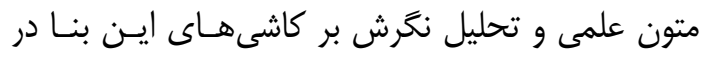

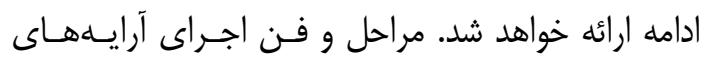

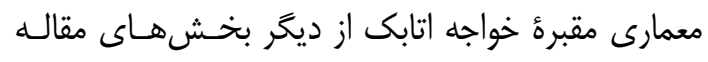

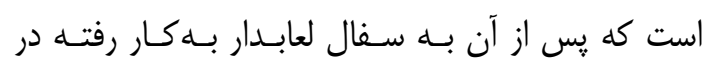
آرايههاى خارجى و داخلى اين بنا يرداخته خواهد شد.

\section{ז. مرورى بر شناخت قديمىترين كاشىهاى

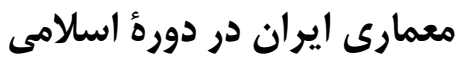

سفال به علت خواص ذاتى خود همـواره مـورد اسـتفاده

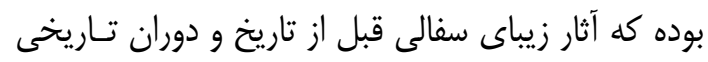

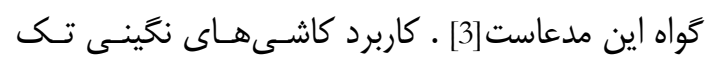

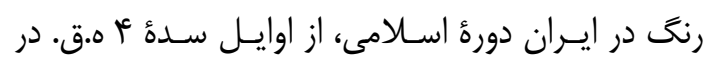

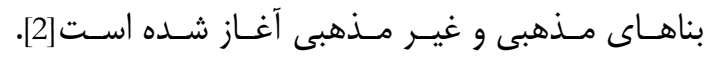

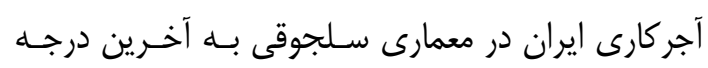

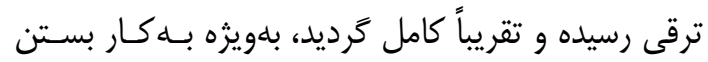

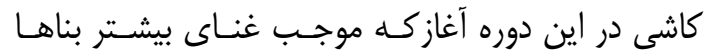
كرديد[4]. عامل جديدى كه در معمارى سلجوقيان يافت

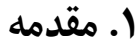

شناخت آرايههاى معمارى ايران از ديدكاه فنشـانـاختى و

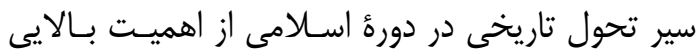

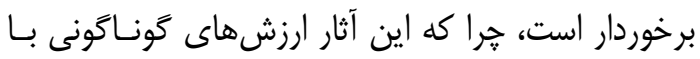

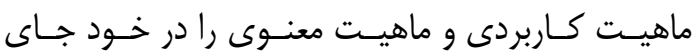

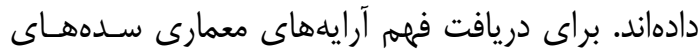

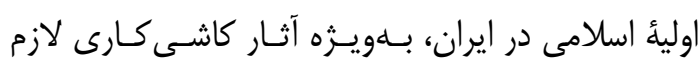

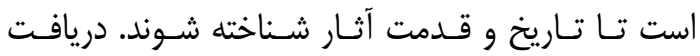
تحولات فنى آرايههاى كاشى نيز مستلزم شناخت تـاريخ

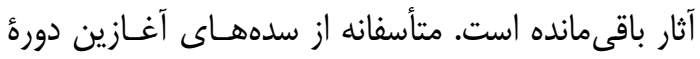

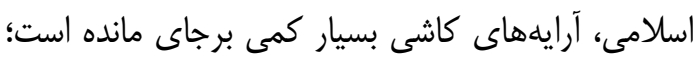

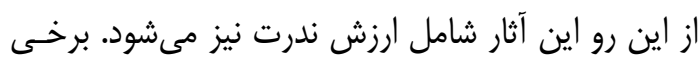

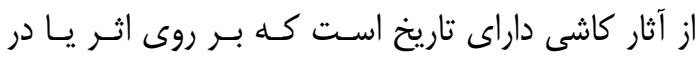

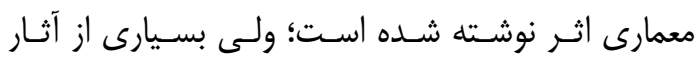

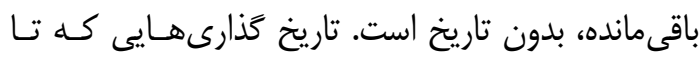

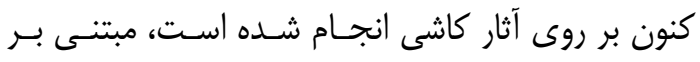

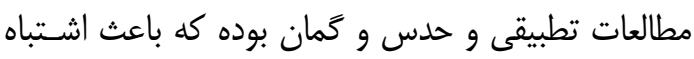

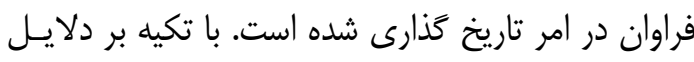

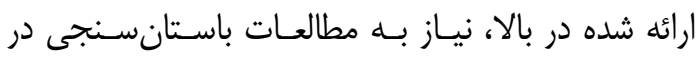
خصوص تاريخ كذارى آرايههاى معمـارى بـهـويـزه آثـار

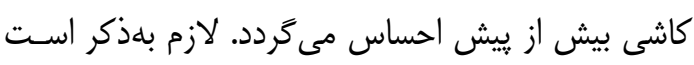

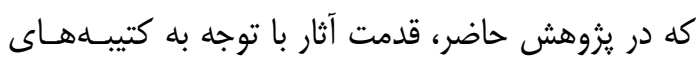

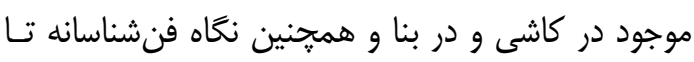
حد زيادى مشخص گرديده است.

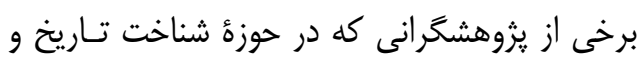

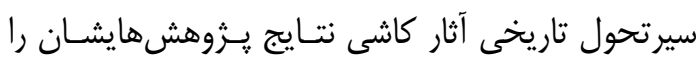
منتشر نمودهاند، (بدون توجه عميق به فن ساخت و اجرا)

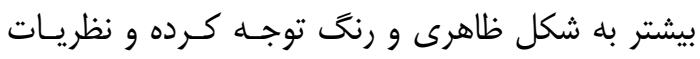

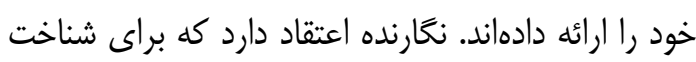
تاريخ اثر بايد تاريخ تحولات فنى اثر ابتدا شــاخته شـود.

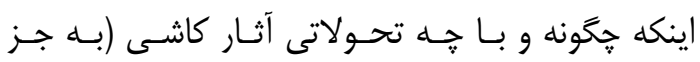

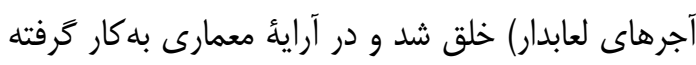

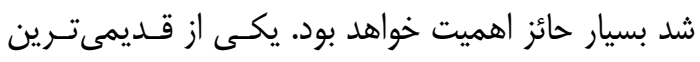

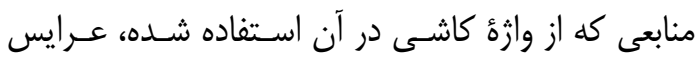
الجواهر و نفايس الاطايب اثر ابوالقاسم عبــالله كاشـانى

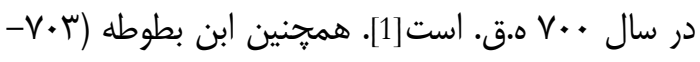


شبستان كَنبددار مسجد جامع قزوين مربوط به سال

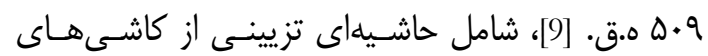

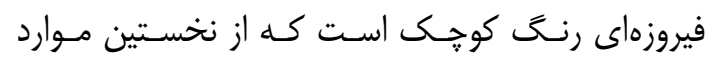

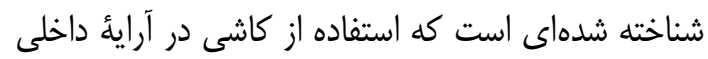

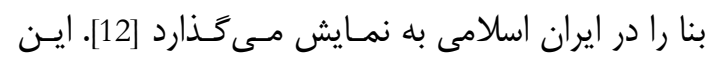

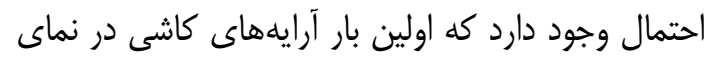

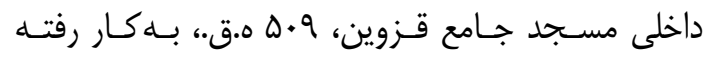

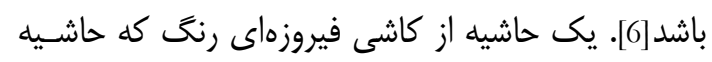

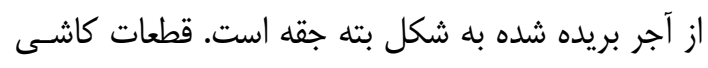

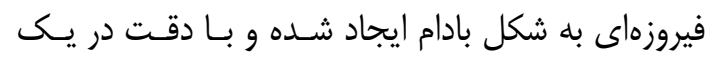

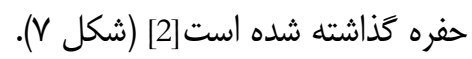
مسجد حيدريأ قزوين بدون تاريخ است اما كَنبدخانهٔ

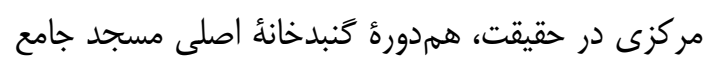

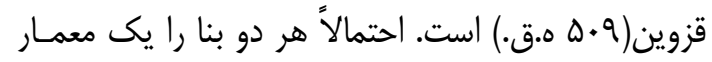

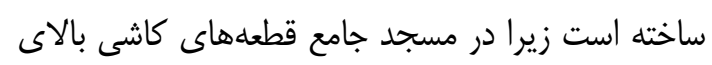

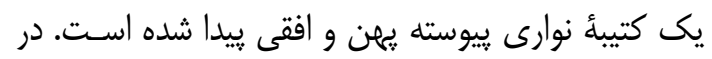

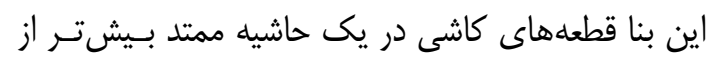

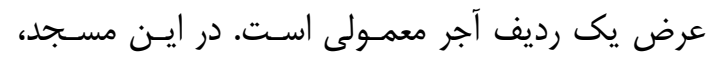

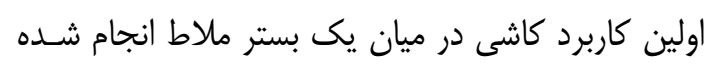

است]2] كارت

در مـورد آثـار كاشـى اوايـل ســــ ششهم، هـوب و

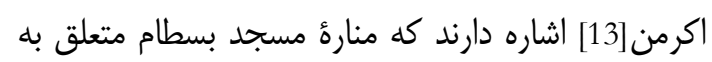

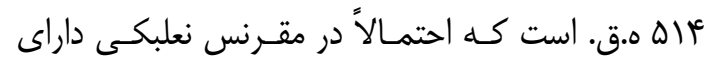
كاشى است. تاريخ وكه ه.ق. مربوط به كتيبئ كوفى لعابدار منـار

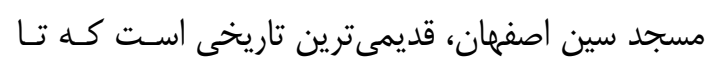

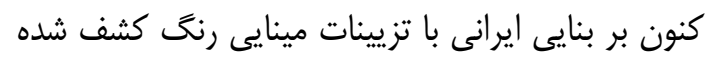
است[14]. مايرون اسميت در مقالهُ خود دربارئ آثار ايـران كئان

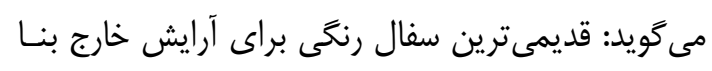

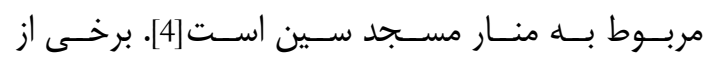

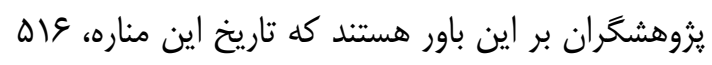

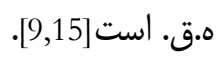

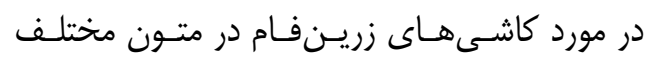

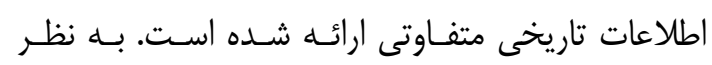

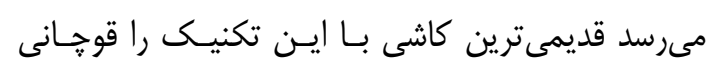

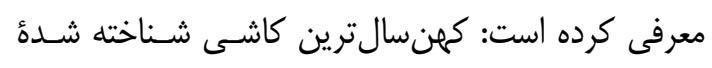

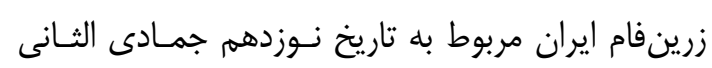

مىشود، استفاده از كاشى اسـت كـه در داخـل و خـارج

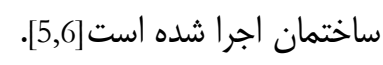

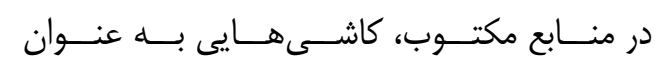

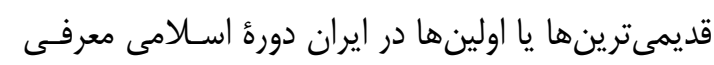

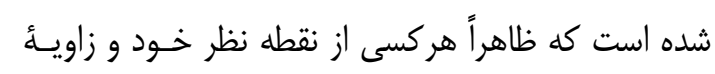

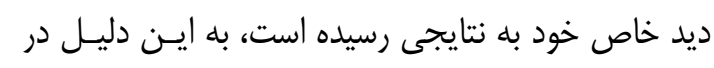

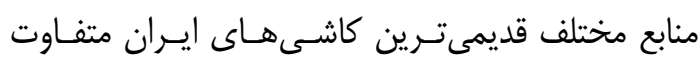

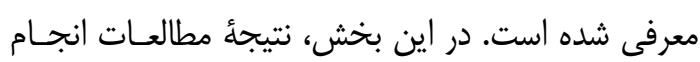
شده در خصوص كهنترين كاشىهاى ايران(با تكيه بــر

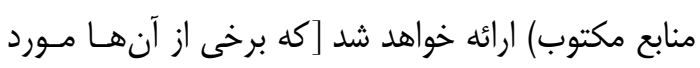

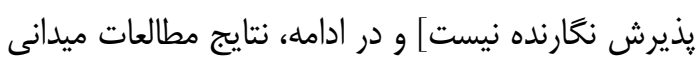

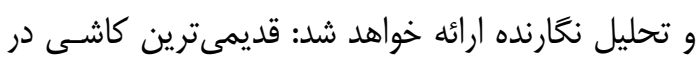
معمارى ايران دورة اسلامى مربوط به مسجد جامئ جامع نطنز

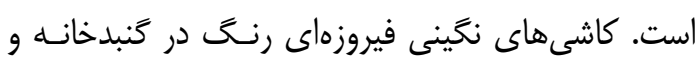

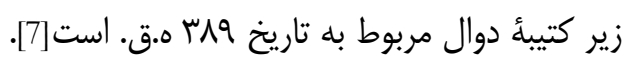

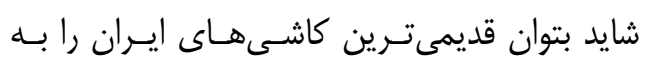

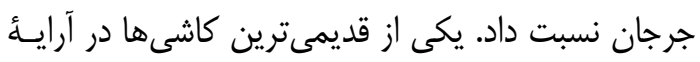

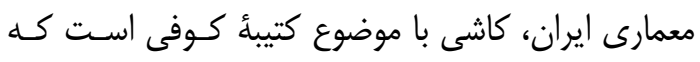
بين آرايههاى آجرى مربوط به به جرجان مانه

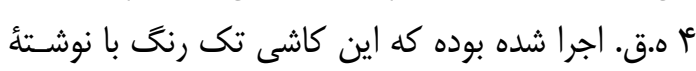

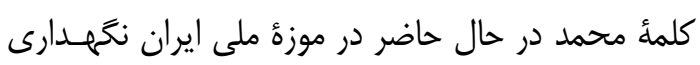

مى شود [9].

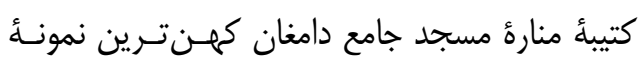
برجاىمانده از كاربرد كاشى در معمارى اسـلامى ايـران

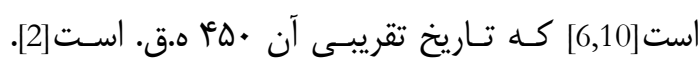

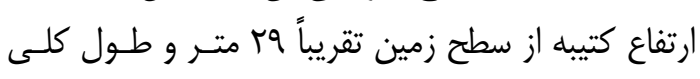

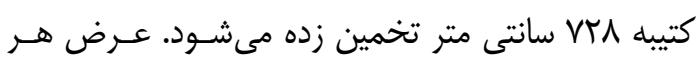

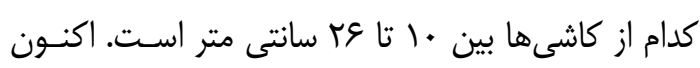

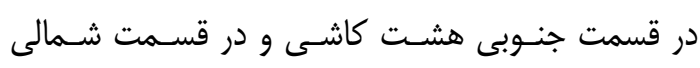

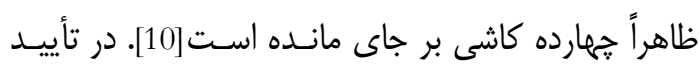

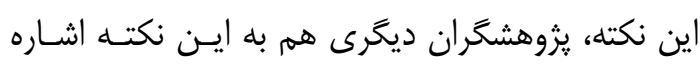

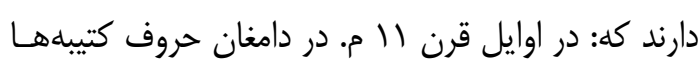

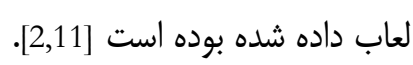
از ديخر بناهايى كه كَفته مى شود داراى كاشى بوده،

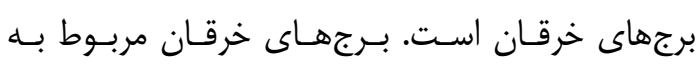

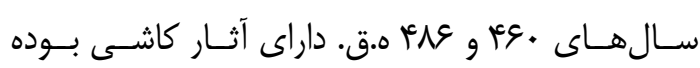
است[9]. 
معمارى ايران در دورة اسلامى

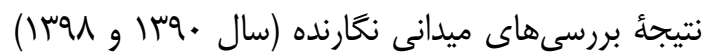

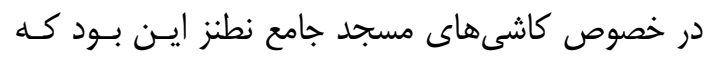

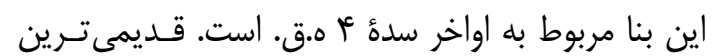

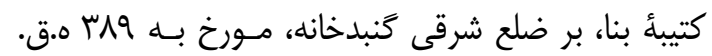

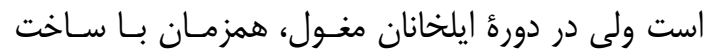

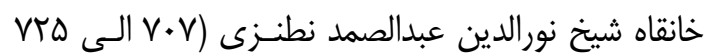
ه.ق.) تغييراتى در آرايههاى معمارى آن داده شده اسـتان،

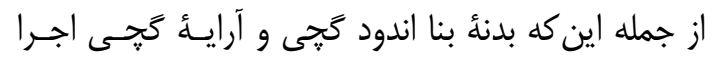
شده است. كاشىهاى نخينى كه اوكين اشاره مى كند، در

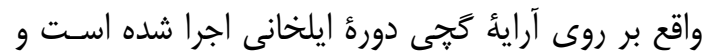

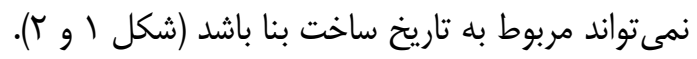
در كريو كَنبدخانة اين مسجد، كتيبة آجرى وجود كه آنه

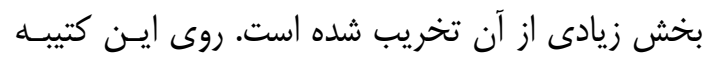

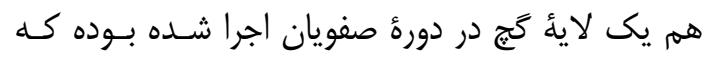
روى آن كتيبئ نوشتارى نقاشى با ظرافت زيادى كار شار دان

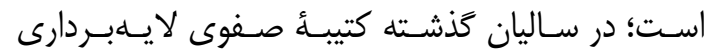

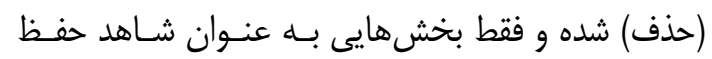

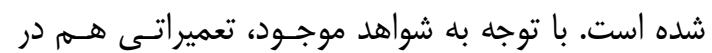

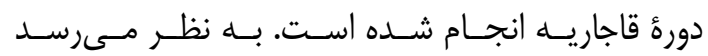

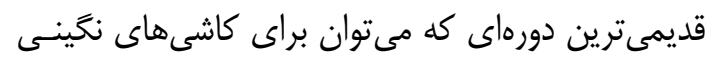

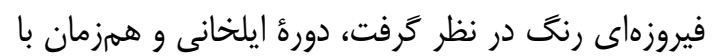

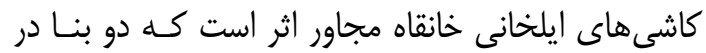
كنار هم و جسبيده به هم ساخته شدهاند. تاريخى كـه در

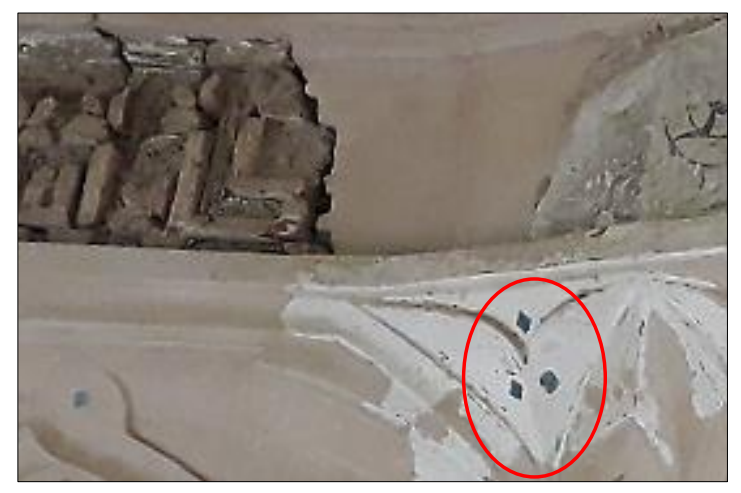

سال qrه ه.ق. در بخش اسلامى موزه [يركامون] برلين

$$
\text { است[16]. }
$$

يكى از ارزشمندترين بناهـاى اواسـط ســــ 9 ه.ق. كنبد سرخ مراغه است كه با كاشىهاى فيروزهاى تـزئين

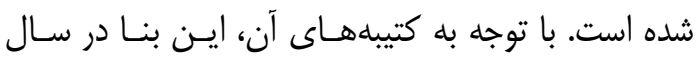

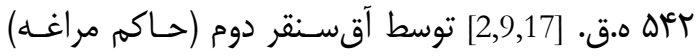
ساخته شده است[16].

حرم مطهر امام هشتم(ع) داراى آرائٔ كاشى سدة

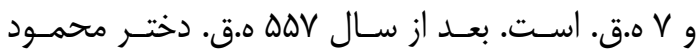
سلجوقى ازاره حرم را با كاشىهاى نفيس شش و هشت

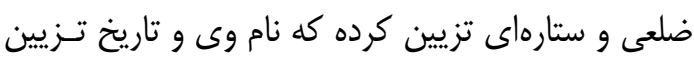
بر كاشىها ثبت است [18]. سردر كَنبد مدور مراغه داراى آرائُ كاشى فيروزهاى

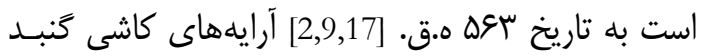
كبود مراغه مربوط به سال سوهم ه.ق. است[13]. از قديمىترين كاشىهاى زيرلعابى در بخش سـردر

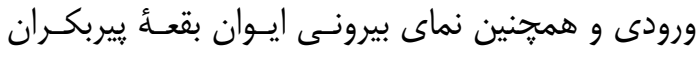

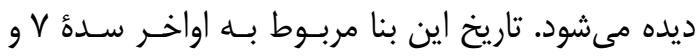

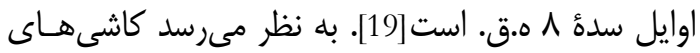

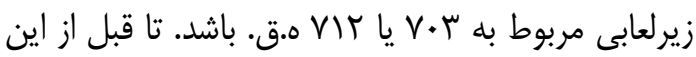

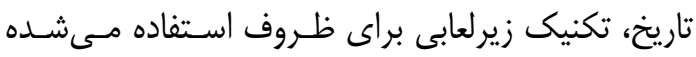
است. اين مورد مىتواند جزو اولين تجربههـاى تكنيـك ترك زيرلعابى در معمارى ايران باشد.

\section{س. تحليلى بر شناخت قديمىترين كاشىهاي}

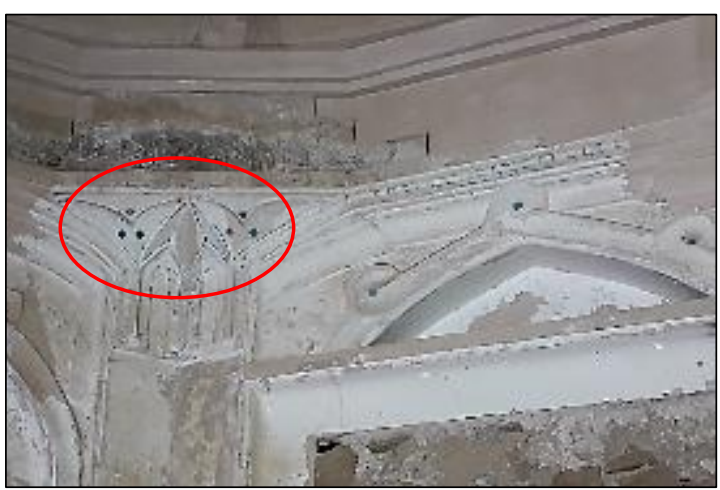

شكل ا. الف و ب: كاشىهاى نكَينى در زير كتيبة آجرى، كنبدخانهُ مسجد جامع نطنز

Fig. 1. (A \& B): Turquoise Tiles in Natanz Jame-Mosque, Iran 

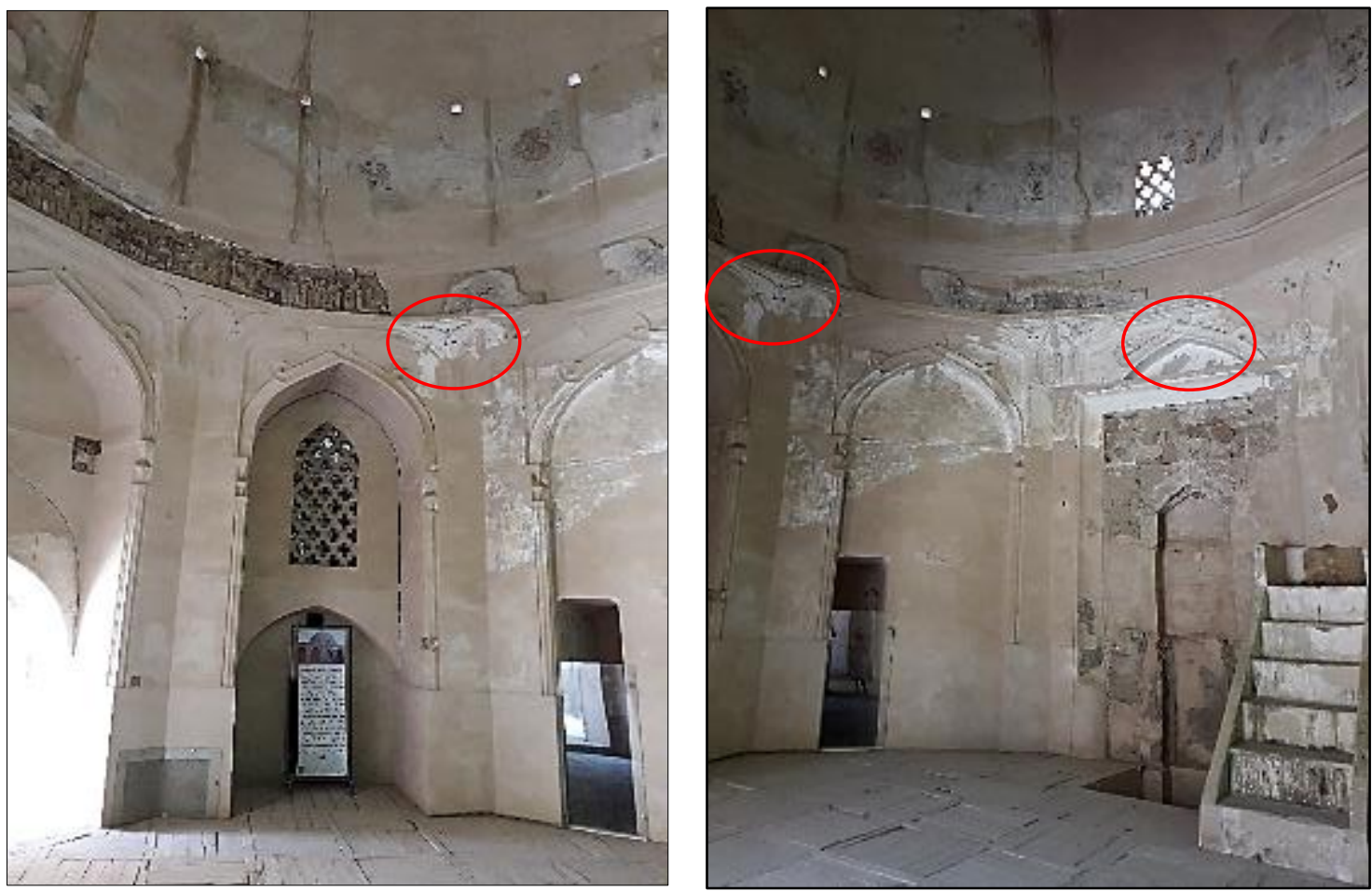

شكل r. الف و ب: كاشىهاى نكينى در زير كتيبة آجرى، كنبدخانه مسجد جامع نطنز

Fig. 2: (A \& B): Turquoise Tiles in Natanz Jame-Mosque, Iran

نظر مىرسد طراحى حـروف در كتيبــُ مـورد نظـر، ايـنـ

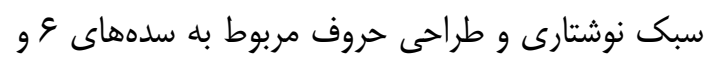

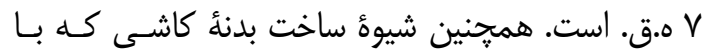

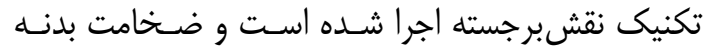

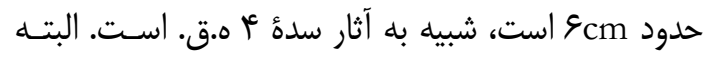
شيوه لعاب دهى بسيار ابتدايى بوده و ضخامت لعـاب در سطوح كتيبه يكسان نيست و در برخى قسـمتهـا شـره

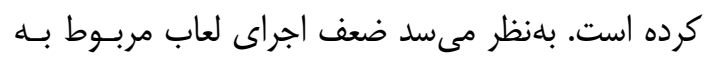

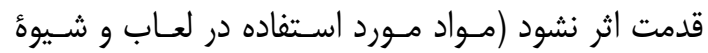
جيدمان آن در كوره بر كيفيت لعاب تأثيركذار است)، زيرا

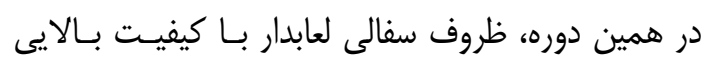

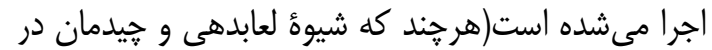

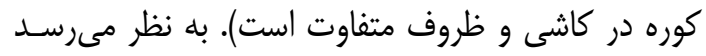
بتوان با نمونهبردارى از لعاب اين كاشى و انجام مطالعات ساختارشناسى بر روى آن و مقايسُٔ نتـايج آن بـا نتـايج

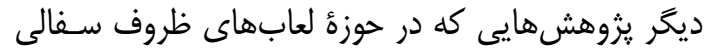

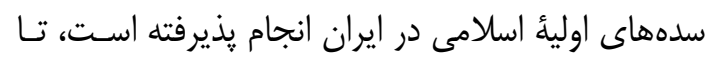
حل زيادى به زمان ساخت اثر بي برد.
كتيبئ كاشى ايوان بقعأه شـيخ عبدالصـمد مشـاهده شـد،

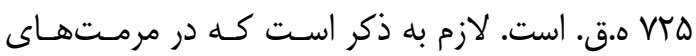

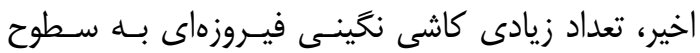
داخلى كَنبدخانه و در محلهاى اصلى، الحاق شده استى

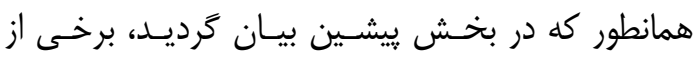

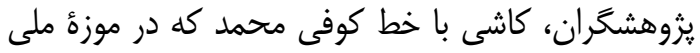
ايران نتحهدارى مىشود (شمارة ثبت

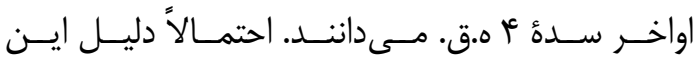
تاريخ كذارى اين بوده كه اين كاشى از نزديكى هاى كنبد

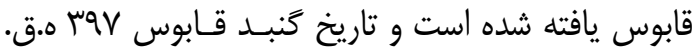
است (شكل بَ و عاء). آجرهاى كنبد قابوس به صورت L شكل اسـت كـهـ بخشى از آجر در ديواره سقف فرو رفته است. طى بازديد إندا

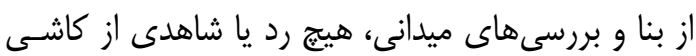
در سطوح خارجى و داخلى بنا مشاهده نشد و با توجه بـــــا سبك معمارى و آرائه معمارى كنبد قابوس، كاشى مورد

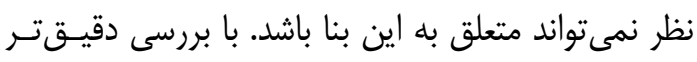

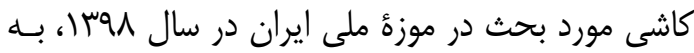



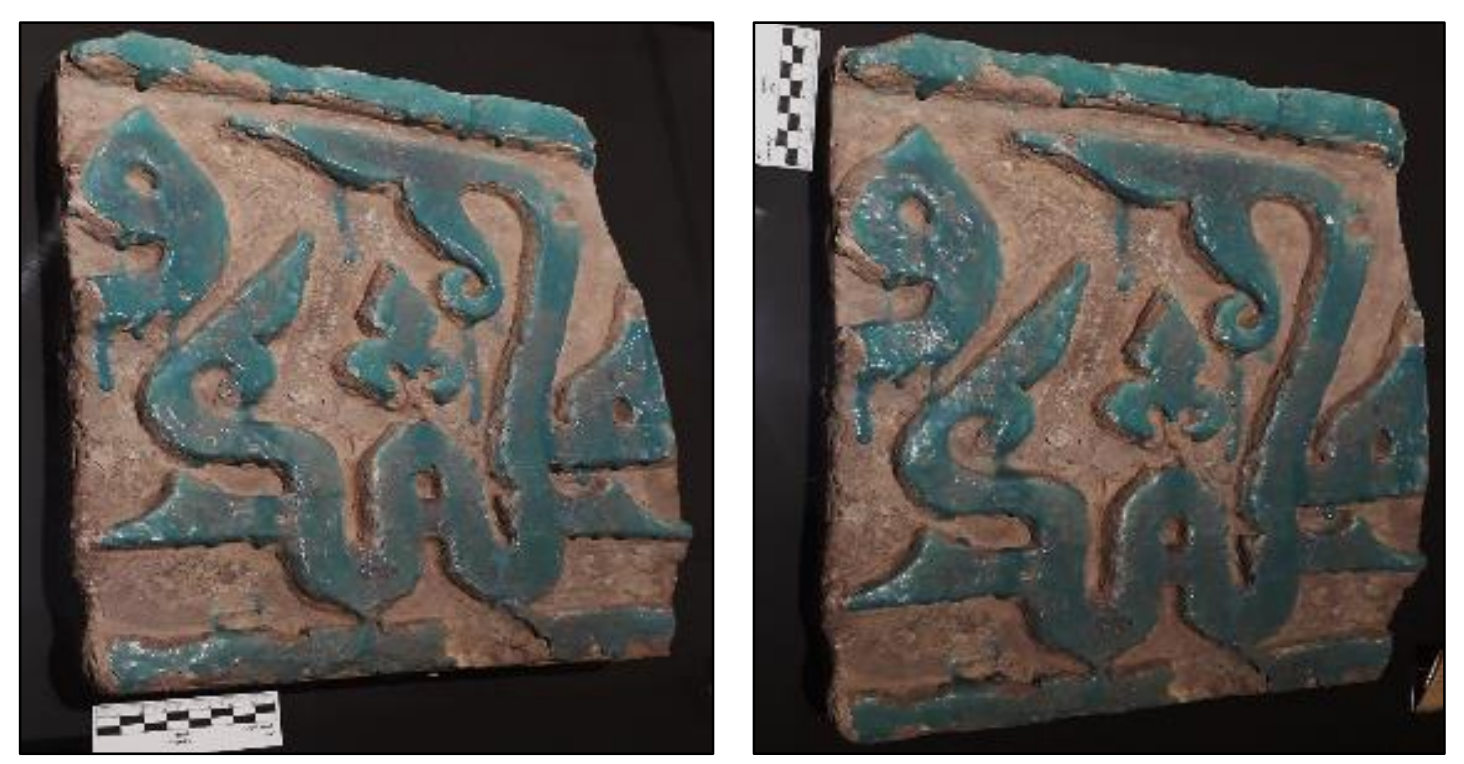

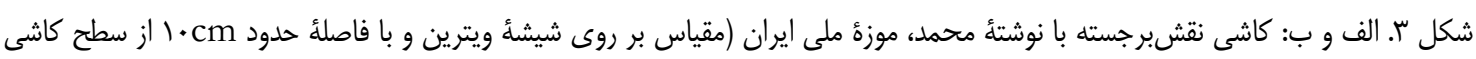

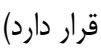

Fig. 3: (A \& B): Relief tile in National Museum of Iran, part of inscription: Mohammad
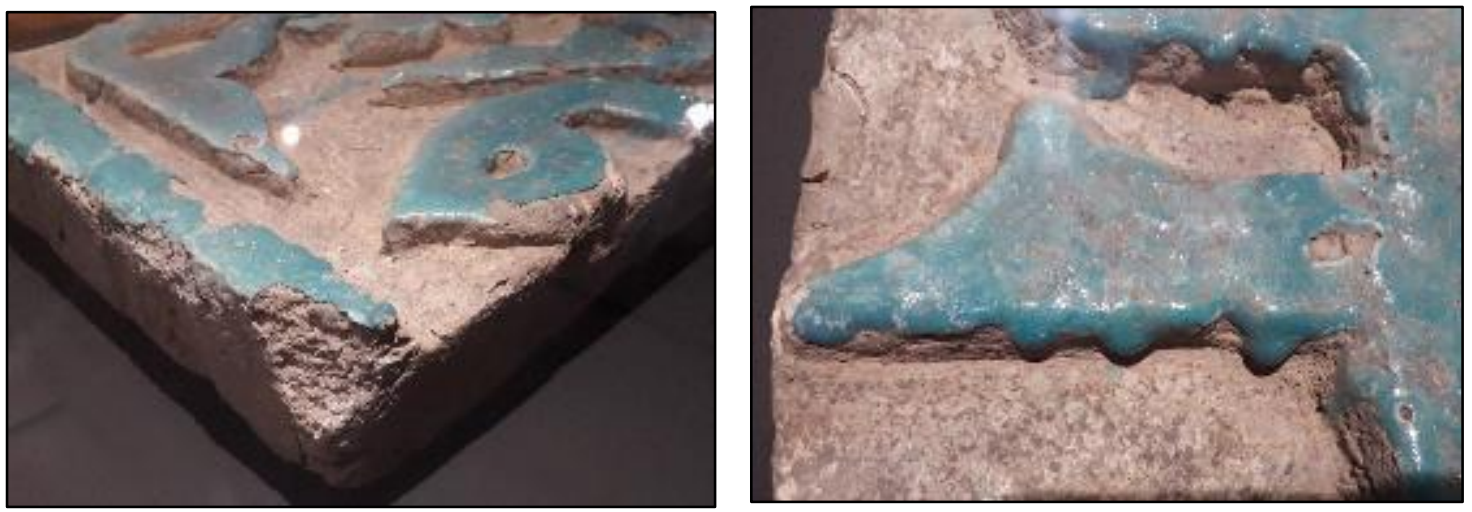

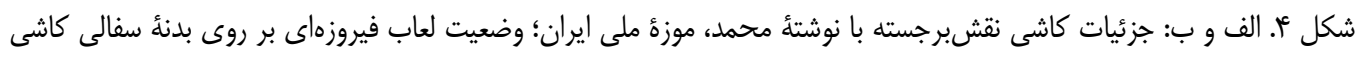
Fig. 4: (A \& B): detail of tile, Turquoise glaze on inscription

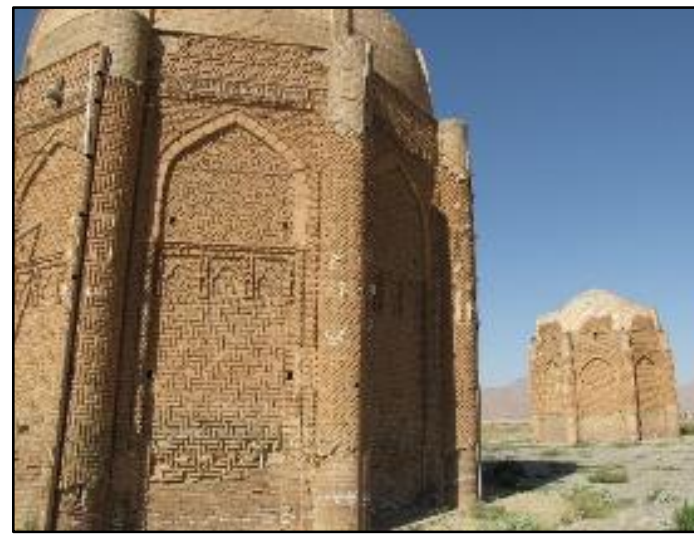

شكل و برجهاى خرقان با آرايهاى آجرى، بدون كاشى Fig. 6: Break arrays of Kharaghan Tower, Iran

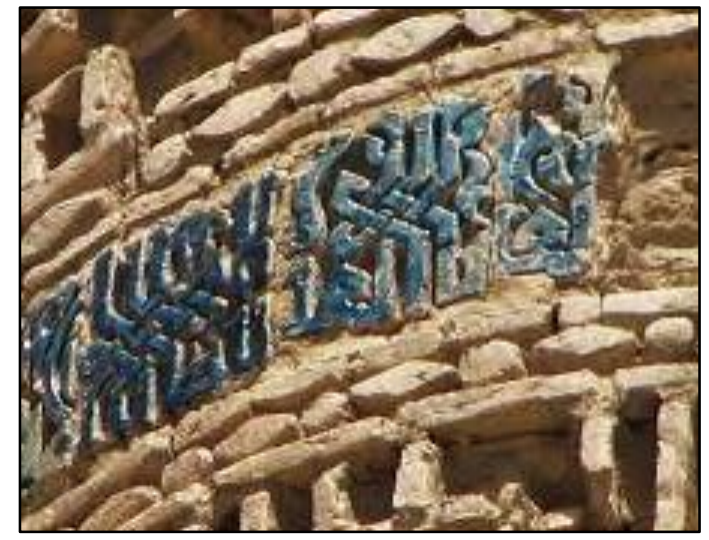

شكل ه. كتيبئ كاشى منارؤ مسجد جامع دامغان

Fig. 5: Tiles of Damghan Jame-Mosque Minaret, Iran

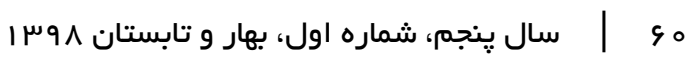


با نقش برجستهُ كتيبئُ كوفى -الملك- كـه بـهـ صـورت زمينه-كود اجرا شده است، (نوشته شده: سـبك نيشـابور

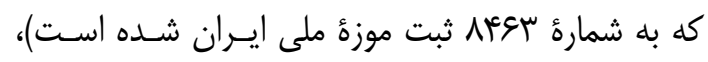

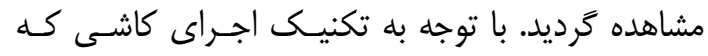

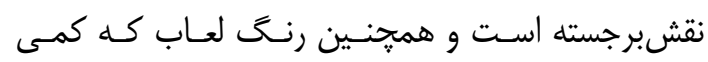

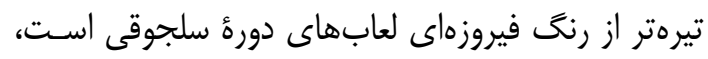

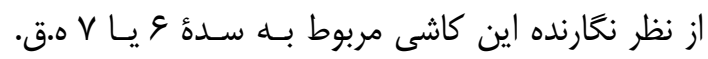

است.

نتيجة بررسى ميدانى كاشىهاى كَنبدخانـه مسـجد

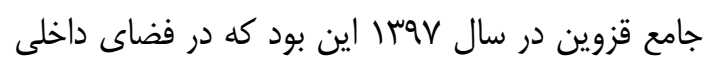

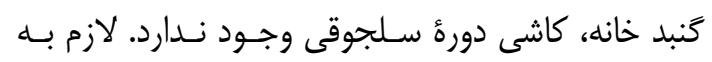

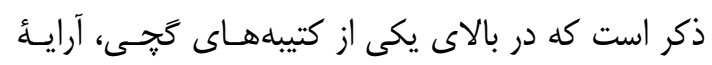

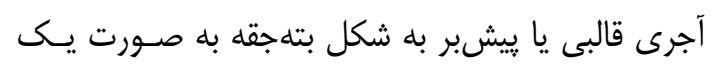

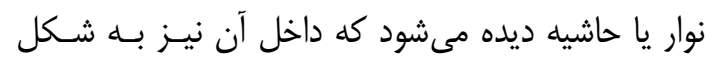

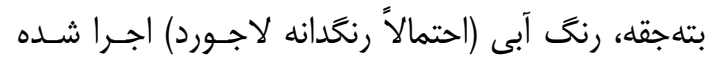

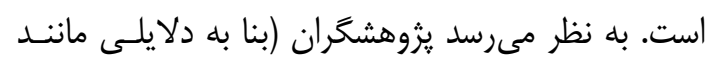

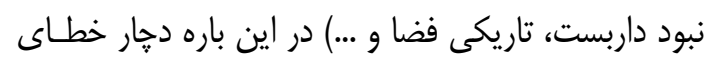

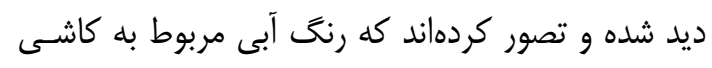

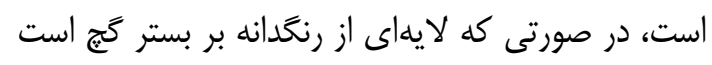

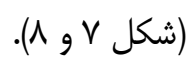

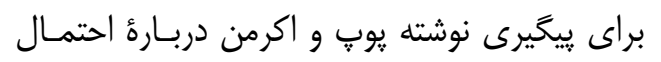

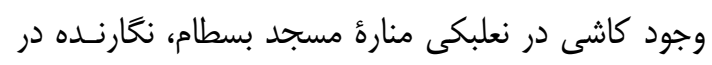

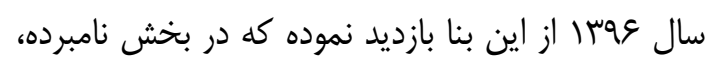

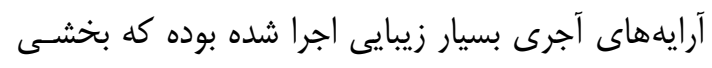

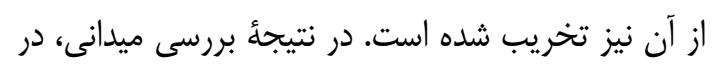
بخش نعلبكى منارة مسجد بسطام، كاشى مشاهده نشد.

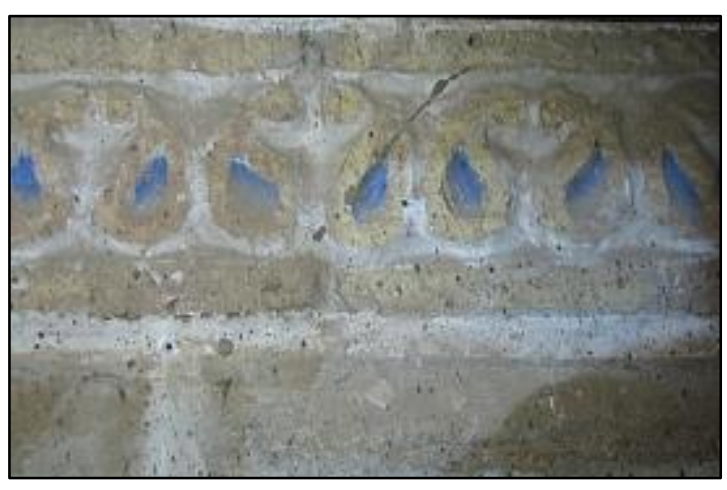

شكل ^ـ آرائُ آجرى و رنحَ آبى در مسجد جامع قزوين

Fig. 8: Brick ornament and blue color, Qazvin Jame-Mosque
با بررسىهاى ميدانى صورت گرفته از كتيبئ كاشـى

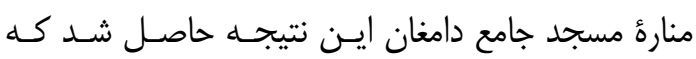

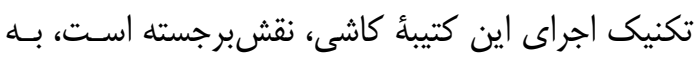

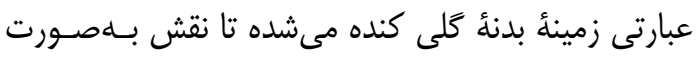

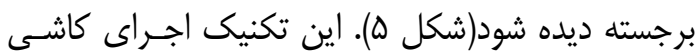

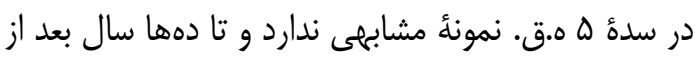

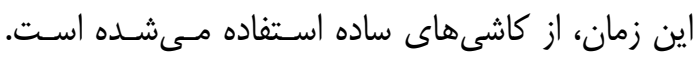

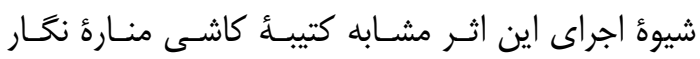

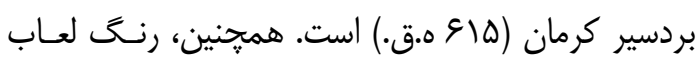
كاشىهاى مناره مسجد جامع دامغان شبيه به آثار كاشى ردى

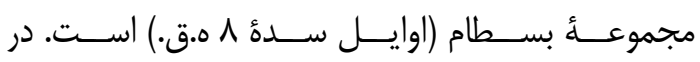

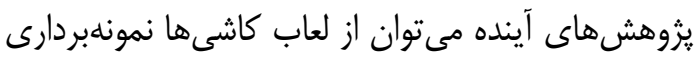
و مطالعات ساختارشناسى دقيق براى يافتن نمونهُ مشـابه

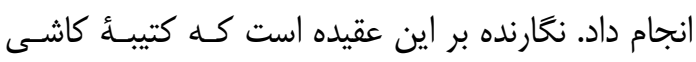
منارة مسجد جامع دامغان متعلق بله سده ه ه.ق. نبـوده و مربوط ببه سدههاى بعد است.

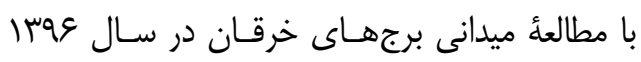
مىتوان كفت كه تمام سطوح خارجى بنا با آرائً آجرى و

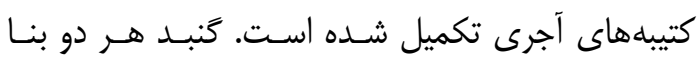

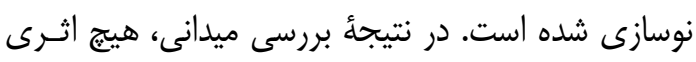

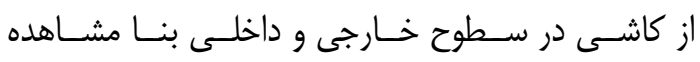

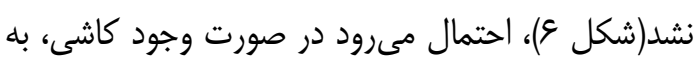

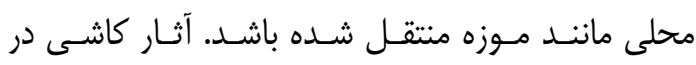
معمارى سده ه ق. ه. بسيار اندك است.

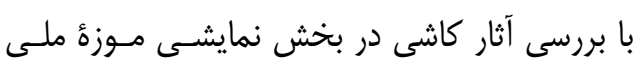
ايران، يك قطعه كاشى تك رنى (فيروزهاى -لاجوردى)

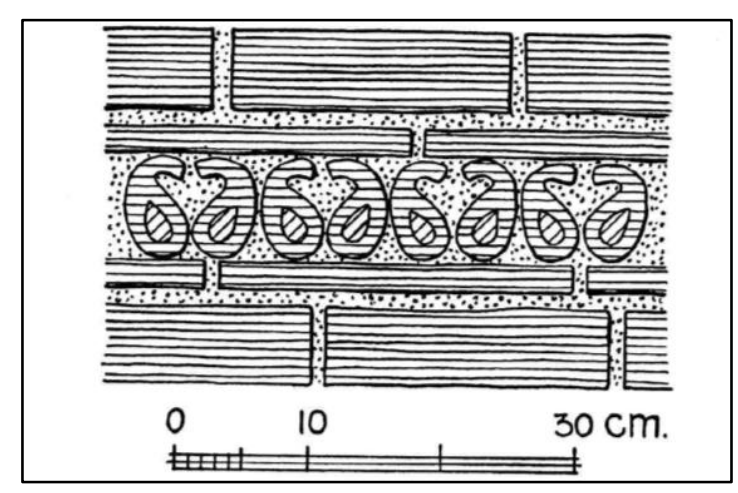

شكل V. طرح شماتيك آرائُ آجرى در مسجد جامع قزوين [1] Fig. 7: Border, Qazvin Jame-Mosque [1]

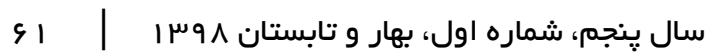



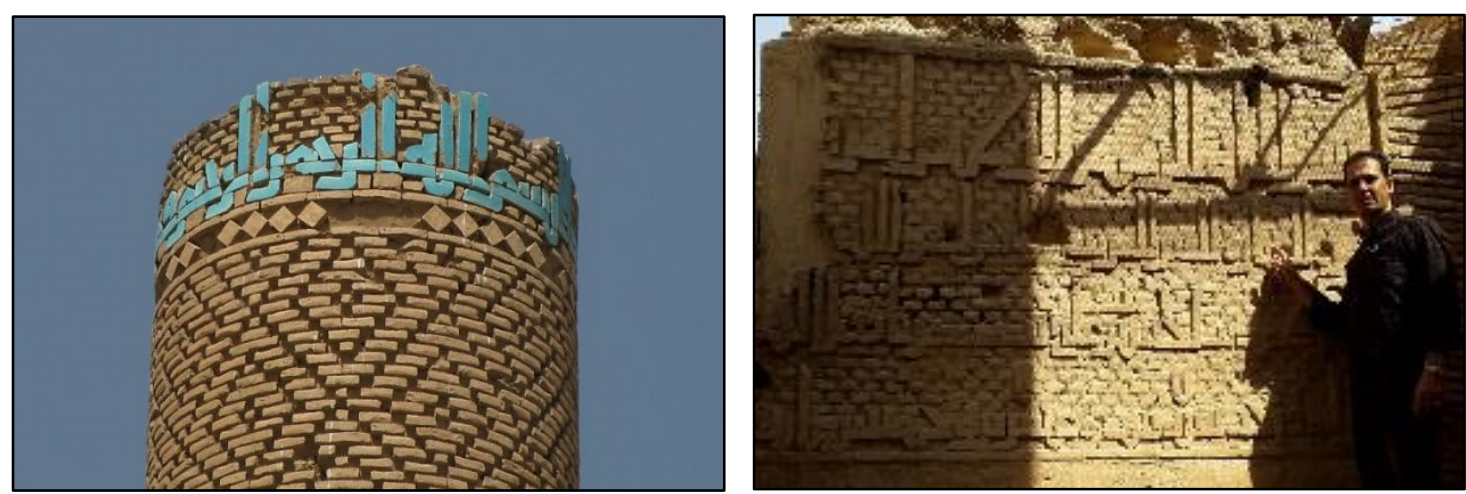

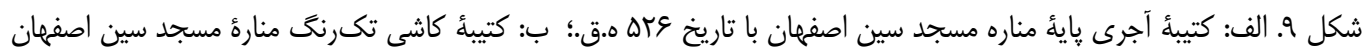

Fig. 9: A: Break inscription, Sin Mosque, Isfahan, Iran. B: Tile inscription in top of Minaret

كاشىها در دورههاى بعد مرمت شده است(به دليل نبـود

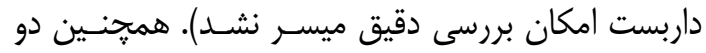

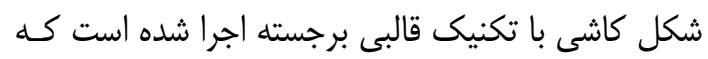

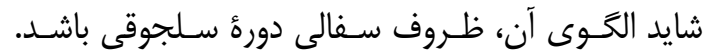

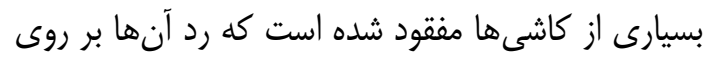

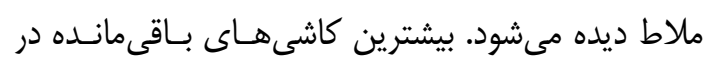

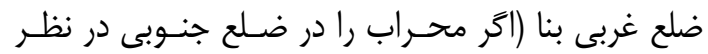
بخيريم) ديده مىشود(شكل • (1).

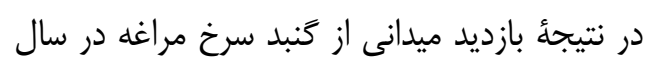

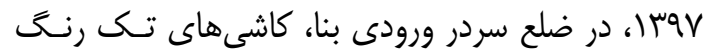

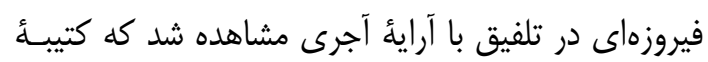

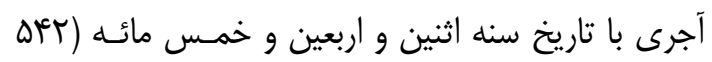

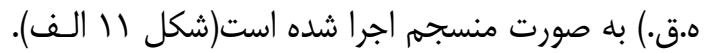

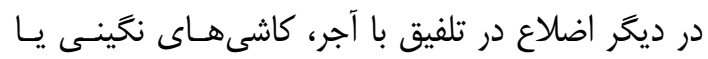

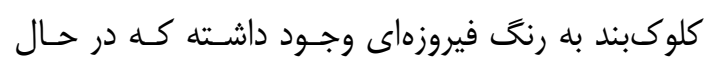
حاضر تعداد كمى از آن باقىمانده و قابل مشاهده اسـت.

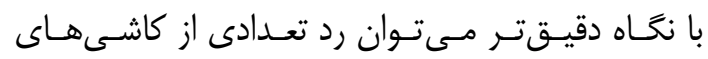

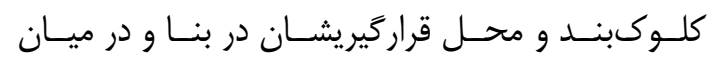
آرايههاى آجرى را مشاهده نمود(شكل لـ لا ب).

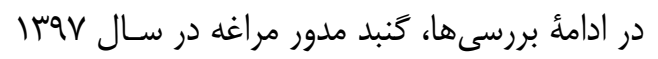

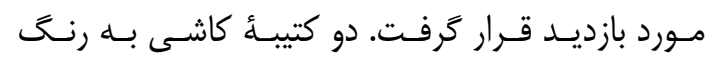
فيروزماى در قسمت سردر بنا وجـود دارد: كتيبـهُ بـالايى

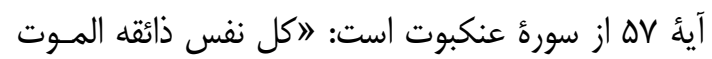

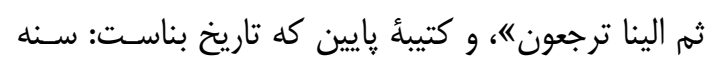

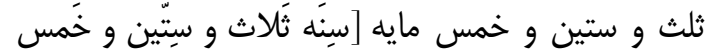

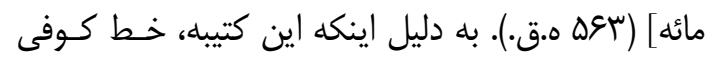

در نتيجأ بررسى دربارة ويزگىهاى نرهكاشسىهاى

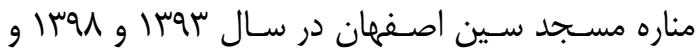

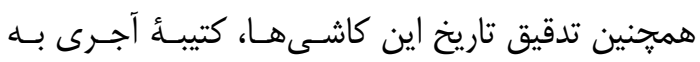

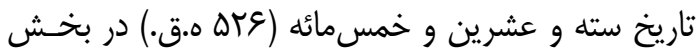

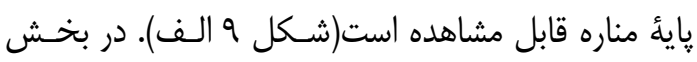

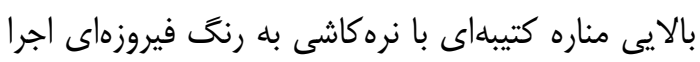
شده است كه رديفهاى بـالاى آن تخريـب شـــه و در واقع، بخش بالايى مناره ناقص است. در تصـوير كتيبــ

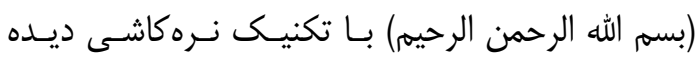
مىشود(شكل 9 ب). لازم به ذكر است كه در داخل بنـا،

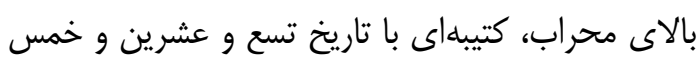

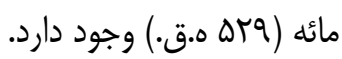

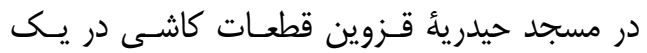

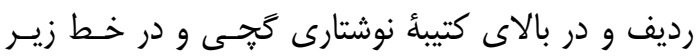

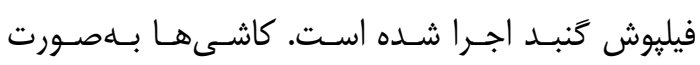

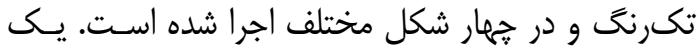

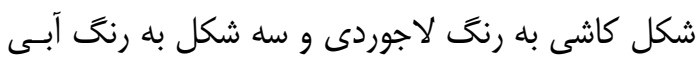

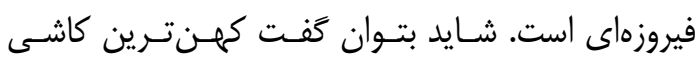
لاجوردى رنخ در معمارى ايـران دورة اسـلامى در ايسن

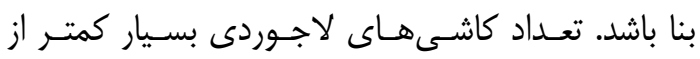

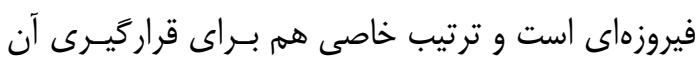

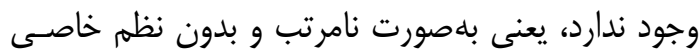

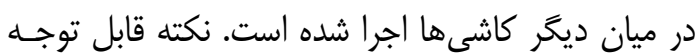

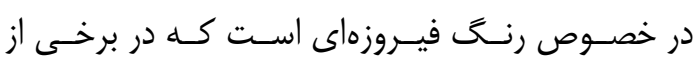
كاشىها متمايل به سبز است. يا در زمان سـاخت، مـواد رداد

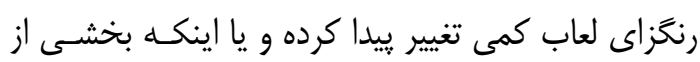



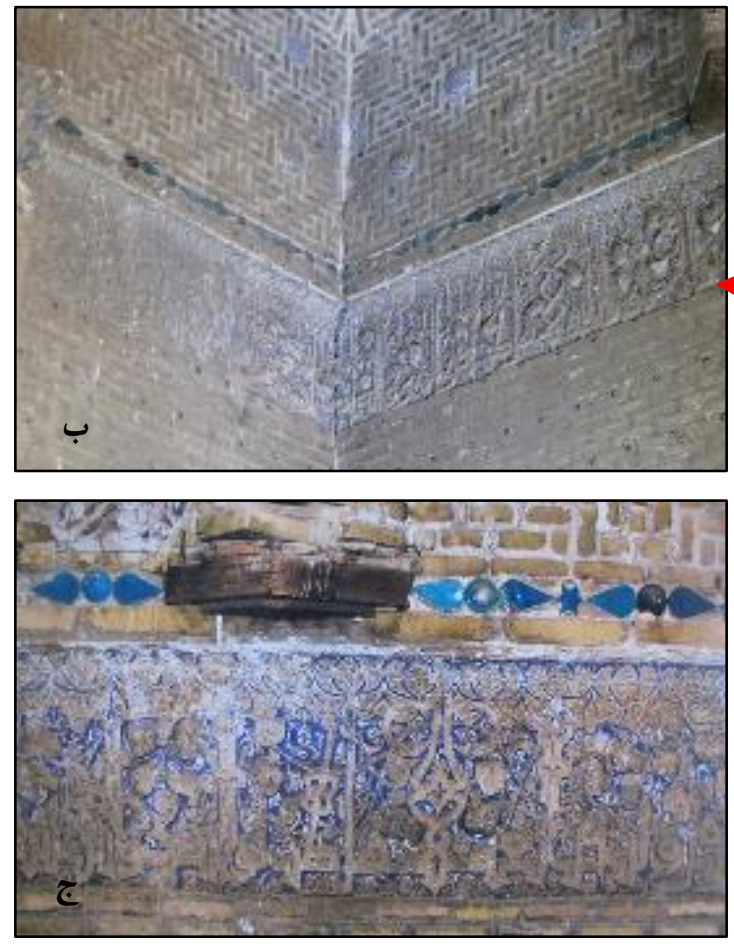

شكل • ا. الف، ب و ج: كاشىهاى تكرنگ مسجد حيدرئُ قزوين؛ منبع تصوير ج: آرشيو اداره ميراث فرهنگى قزوين Fig. 10: Tile works in interior space of Heydarieh Mosque, Qazvin, Iran.
نداشت. كاشىهاى تاريخدار زرين فام كـه در ازاره حـرم

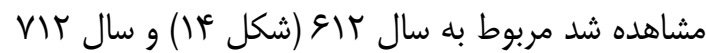

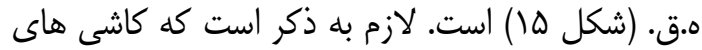

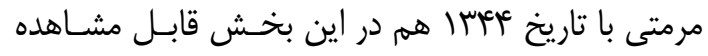

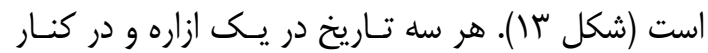
هم اجرا شده است.

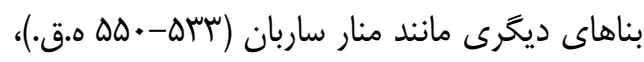
منار مسجد على و منار زيار اصفهان (سده و ه.ق.)، گنبد ماند

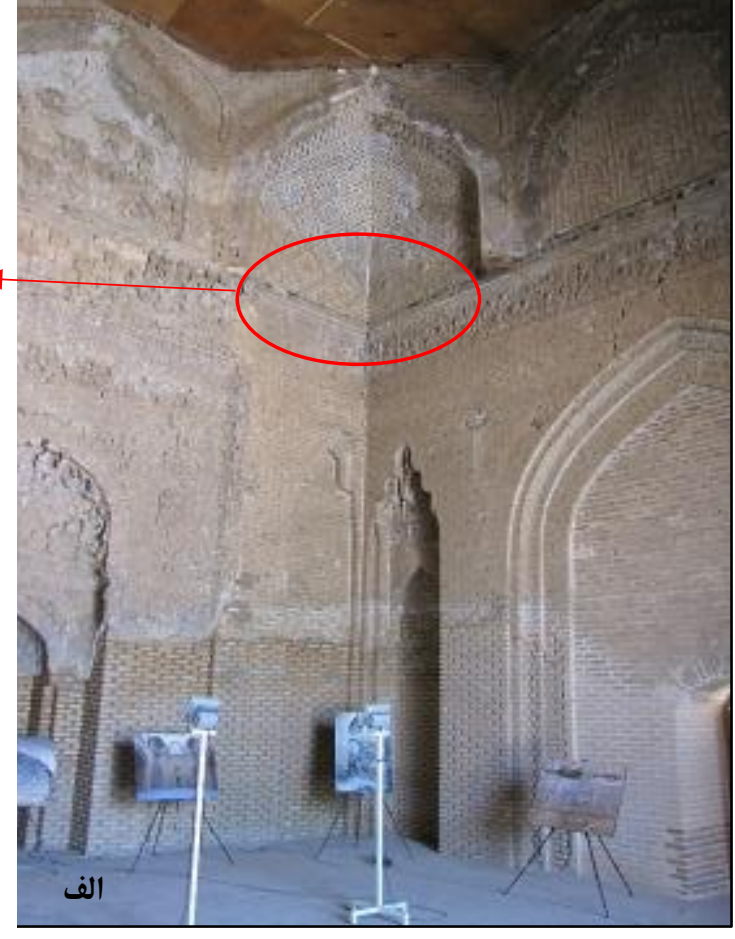

تزيينى است، ظاهراً يوض يكى از نقوش را به جاى حرف

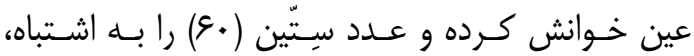

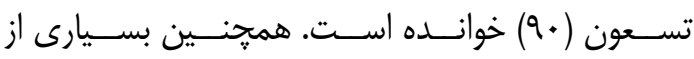

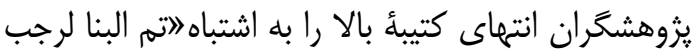
" خواندهاند (شكل r)...

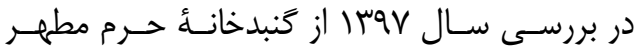
رضوى (مشهر خراسان) به دليل شرايط خاص و جمعيت زياد و محدوديتهاى موجود، امكان مطالعأ دقيق وجـود

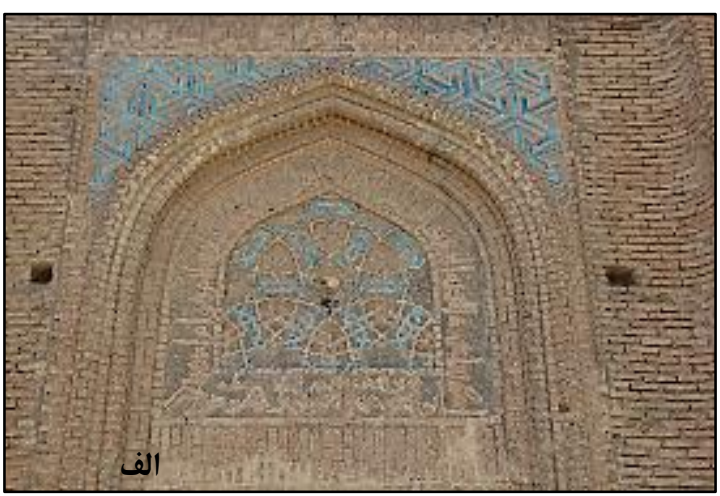

شكل II. الف: كاشى تكرنگ سردر گنبد سرخ مراغه؛ ب: كاشى تكرنگ كلوكبند در ميان آرايههاى آجرى كنبد سرخ Fig. 11: Tile works in exterior side of Maraghe Sorkh Dome, Iran.

$\varsigma^{\mu}$

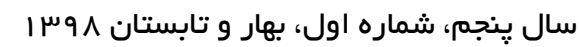




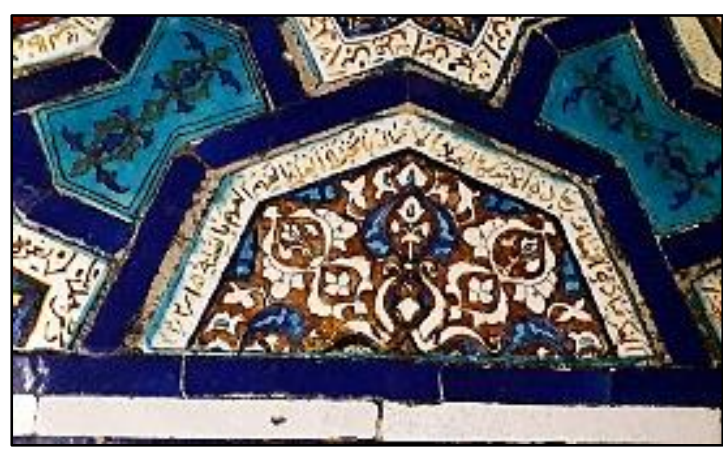

شكل سا. كاشى زرينفام حرم رضوى با تاريخ ع

Fig. 14: Luster tile in Mashhad, Date: 1965 AD

معمارى بقعهُ خواجه اتابك كرمان است با اين تفاوت كه

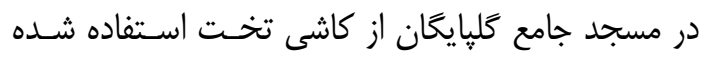

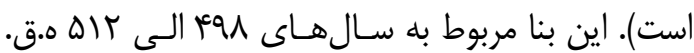

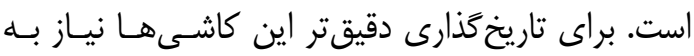

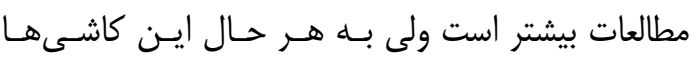

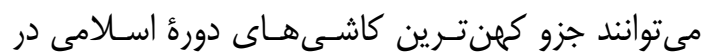
فضاى داخلى معمارى ايرانى باشد.

\section{f. مرورى بر مطالعات باستانسنجى در}

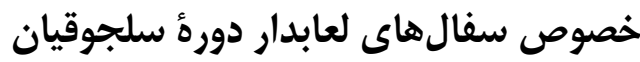

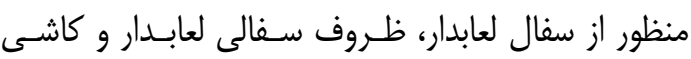

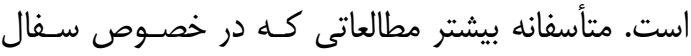
لعابدار دورة سلجوقى انجام شده است به زبان غيرفارسى دئ دانس

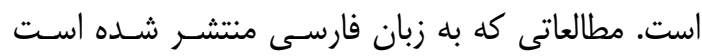
بيشتر از منظر تاريخى و موضوع نقاشى و شـكل و فـرم

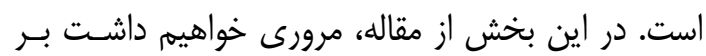

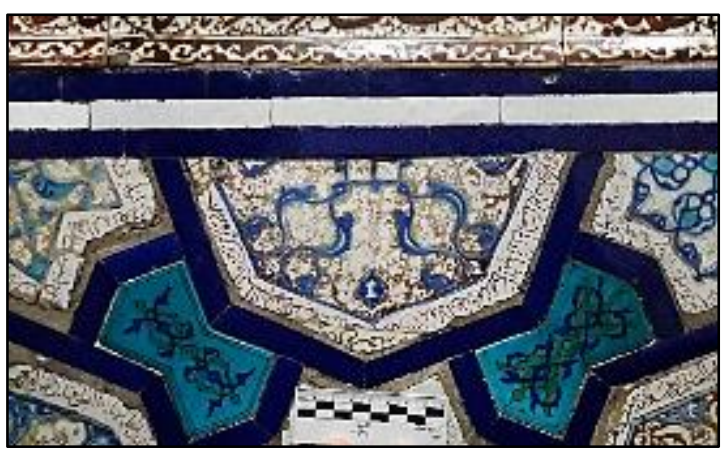

شكل ها. كاشى زرينفام حرم رضوى با تاريخ

Fig. 15: Luster tile in Mashhad, Date: 1316 AD

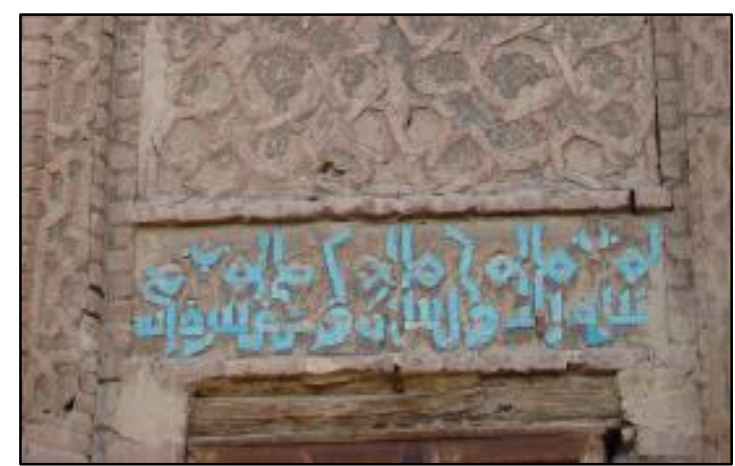

شكل rا. كتيبة كاشى فيروزهاى كنبد مدور با تاريخ سَهه ه.ق. Fig. 15: Tile works in exterior side of Modavar Dome, Iran

كبود مراغه ("هو ه.ق.)، كاشى زرين فـام حـرم حضـرت

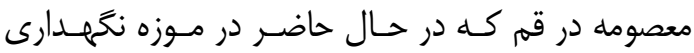

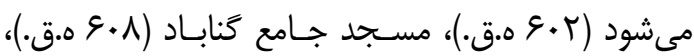

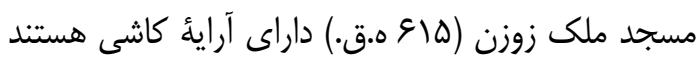

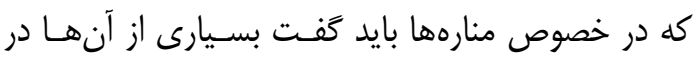

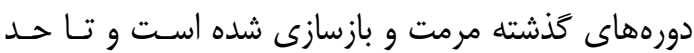

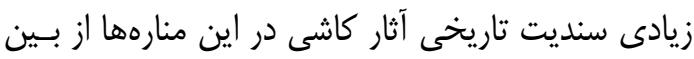

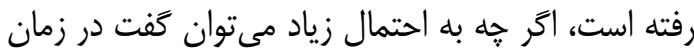

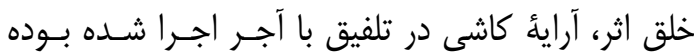
است. همجنين تك كاشى قالبى نقشبرجسته فيـروزهاى

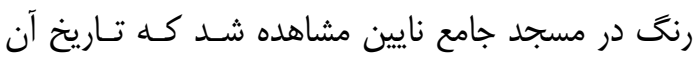
مشخص نيست.

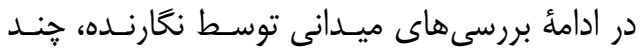

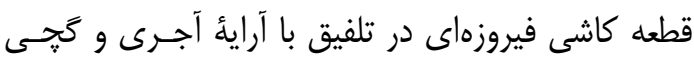

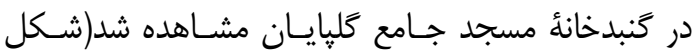

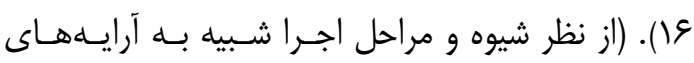

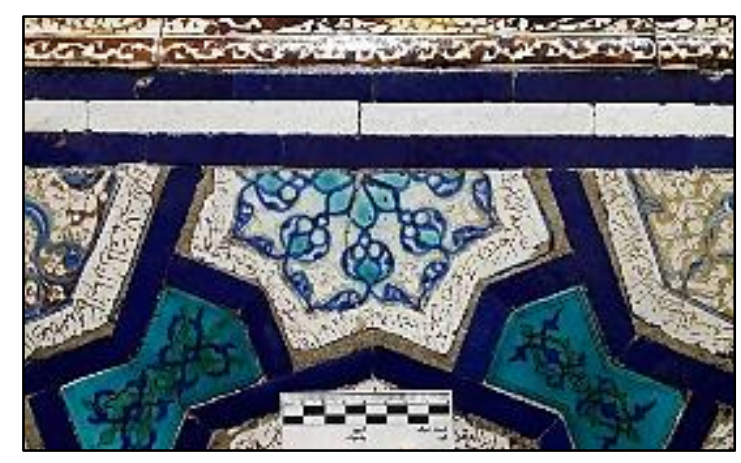

شكل ع ا. كاشى زرينفام حرم رضوى با تاريخ rاء

Fig. 14: Luster tile in Mashhad, Date: 1216 AD

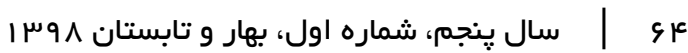




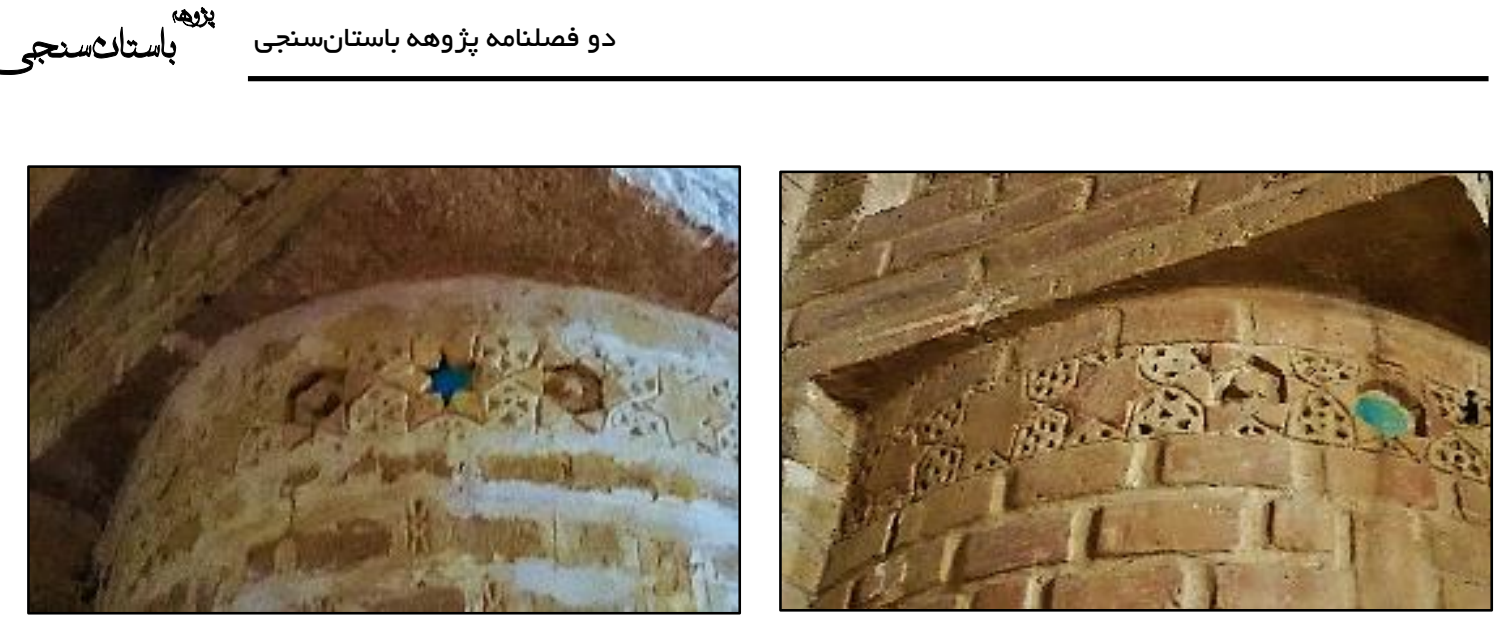

شكل عا. كاشى فيروزهاى رنح در تلفيق با آجر و گج در بخش بالايى ستونهاى شبستان، مسجد جامع كليايكان، استان اصفهان Fig. 16: Tile works in interior space of Golpaygan Jame-Mosque, Iran

انجام يذيرفته است كه عناصر موجـود در لعـابهـاى دو

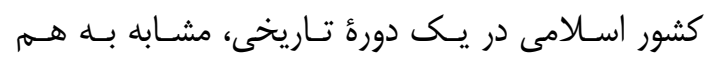

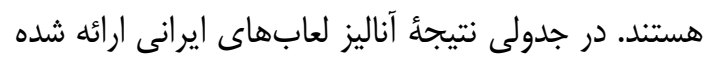

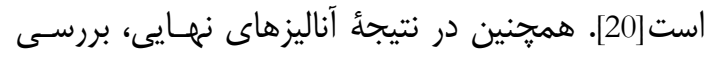

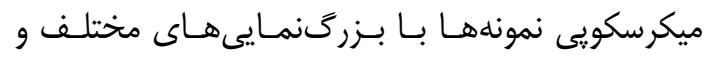

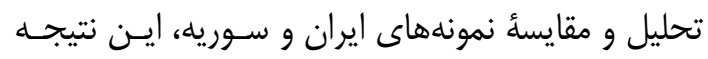

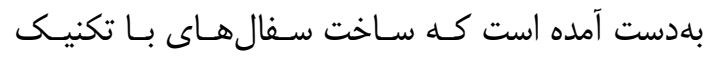

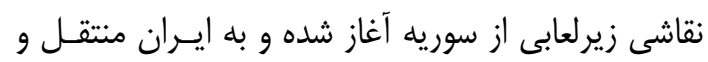

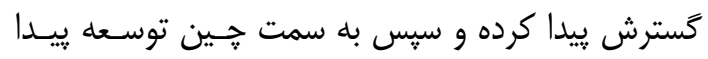
كرده است[20].

در مقالهاى، تكنولوزى توسعُ سراميكهاى اسلامى

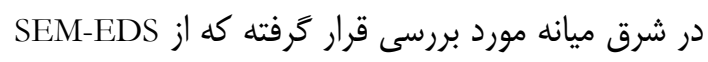

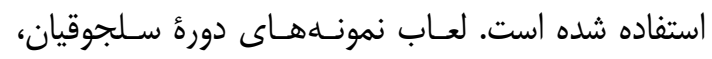

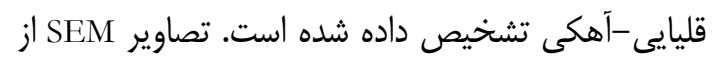

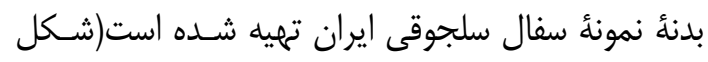

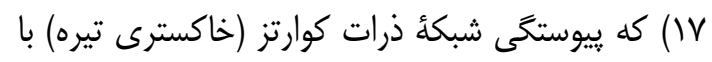

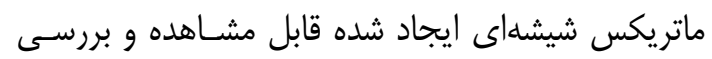

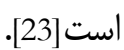

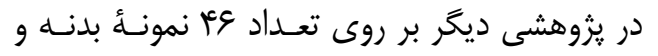

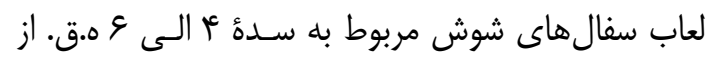

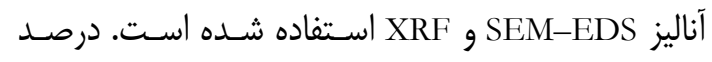
بالايى از لعابهاى مورد بررسى، سربى -قليايى هستند و اليز

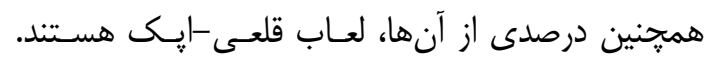

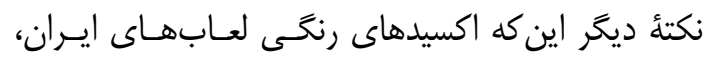

عراق، سوريه و مصر با يكديكر متفاوت هستند [24].

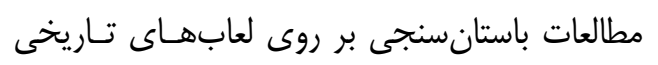

مطالعـات فنـى و ساختارشناسـى انجـام شـــه بـر روى

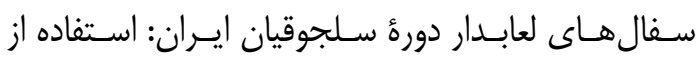

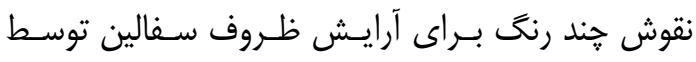

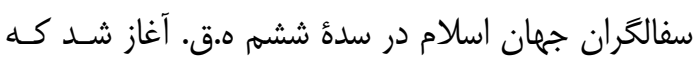

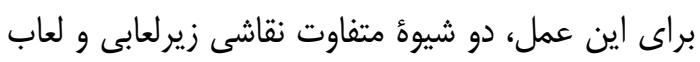

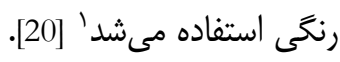

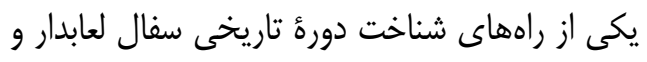

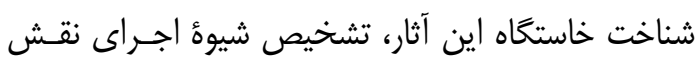

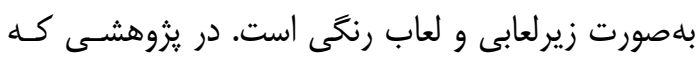

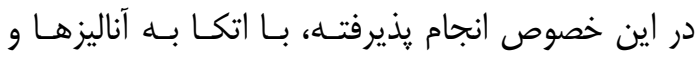

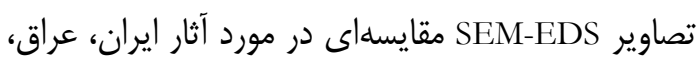

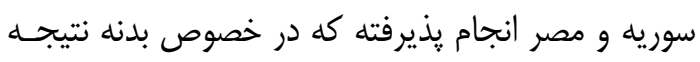

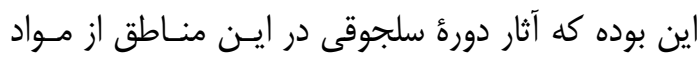

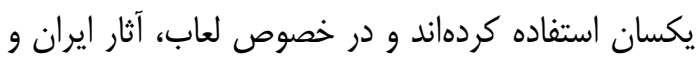
مصر در اين دوره مشابه هم كار شده است [21].

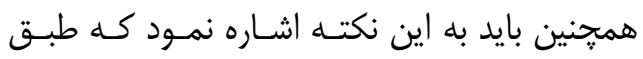

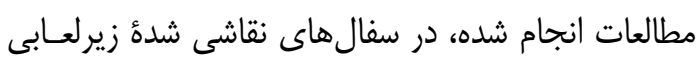

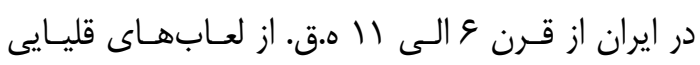

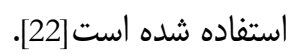

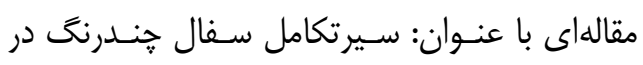

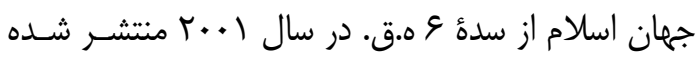

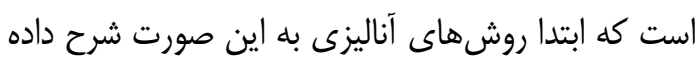

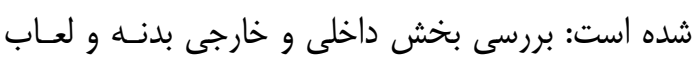

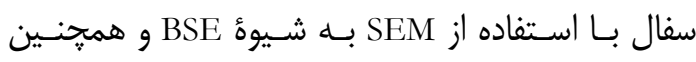

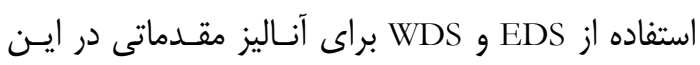

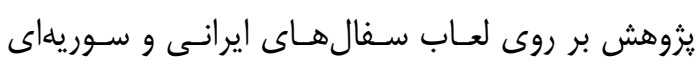



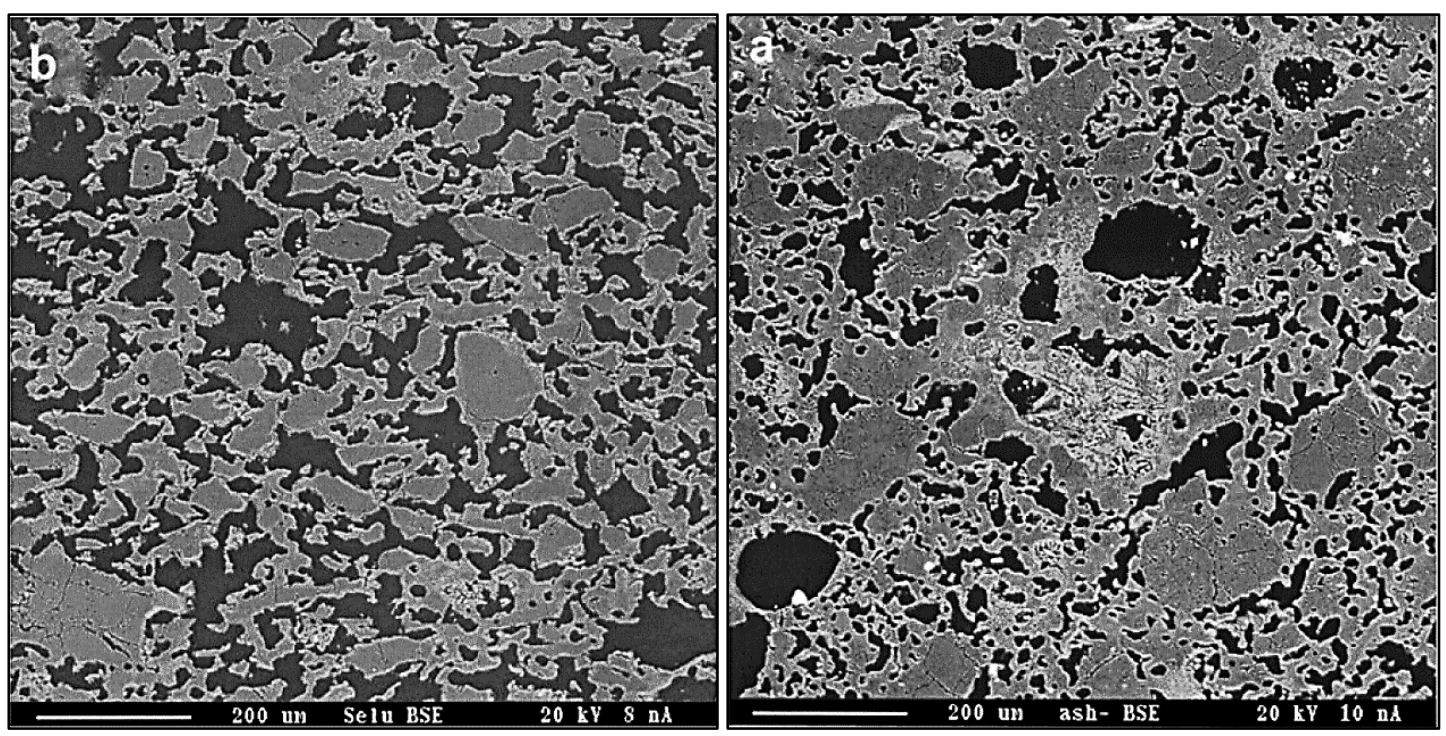

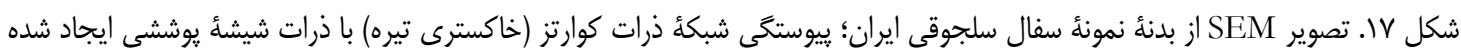

است[23].

Fig. 17: SEM photomicrographs for bodies of Seljuk Lustre sherd from Iran.

سفال ها از نوع لعاب سفيد با نقوش سبز و آبى كبالـت و والت قالب فشارى است. نتيجأ مطالعات حاكى از آن است كه

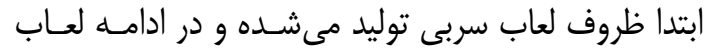

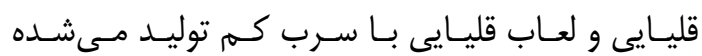

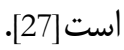
يكى از تكنيكهاى سـاخت سـفال لعابـدار در دورةٔ

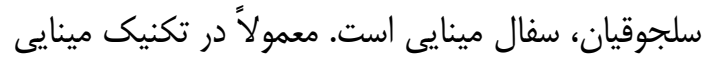

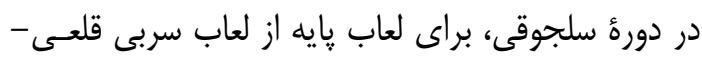

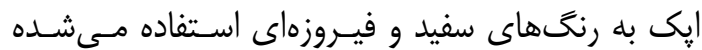
است. اكسيد قلع براى إيى كردن دو رنح كاربرد داشته كه براى بلهدست آوردن رنح فيروزهاى از مس اسـتفاده مىشده است[20,28]. در مقالهاى بـاعــــــان: آنـاليز سـفالهـاى منقـوش ميناى ايرانى، براى شناسايى رنحَها و تركيبات مختلـف

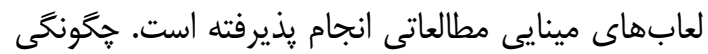
نقاشى و يخت لعابها بستخى به كاربرد آثار، متفـاوت بوده است. در نمونههاى مورد مطالعه، هر دو شيؤ لعاب يايأ سفيد و فيروزهاى موجود بوده است. نمونههاى مورد

مطالعه مربوط به قرن ششم و هفتم 0.ق. است[29].

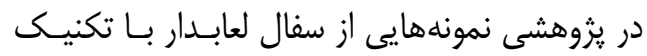
مينايى مربوط به دورة سلجوقيان بـا اسـتفاده از XRD و و
سفالهاى استونور و يرسلين جين و ايسران نشـان داده

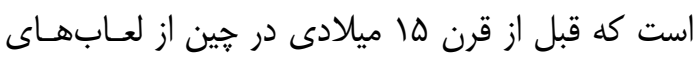

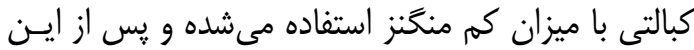

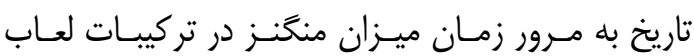
كبالتى زيادتر شده است در صورتى كه در ايـران اينطور

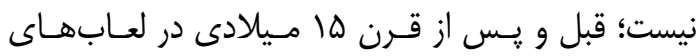

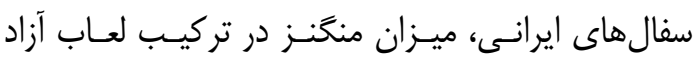

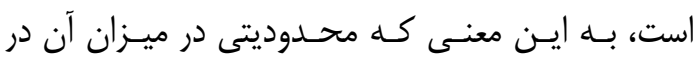

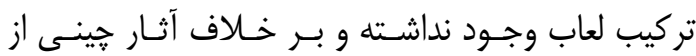
ابتداى تاريخ ذكر شده، ميزان منَنز در تركيب لعاب زياد

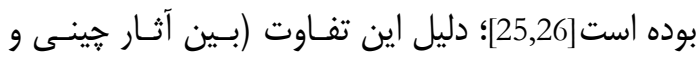

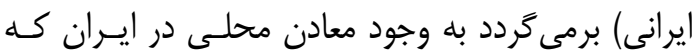

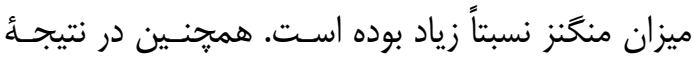

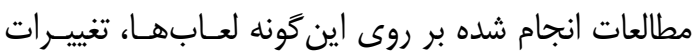

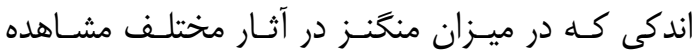
مى شود مربوط به تفاوت در معادن مختلف است كـه در معادن محلى، ميزان عناصر مختلف اندكى متفاوت بـوده

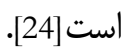

بر روى نمونههايى از سفالهاى لعابدار ايران مربوط

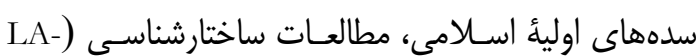
(ICP-MS \& TOF-ICP-MS 

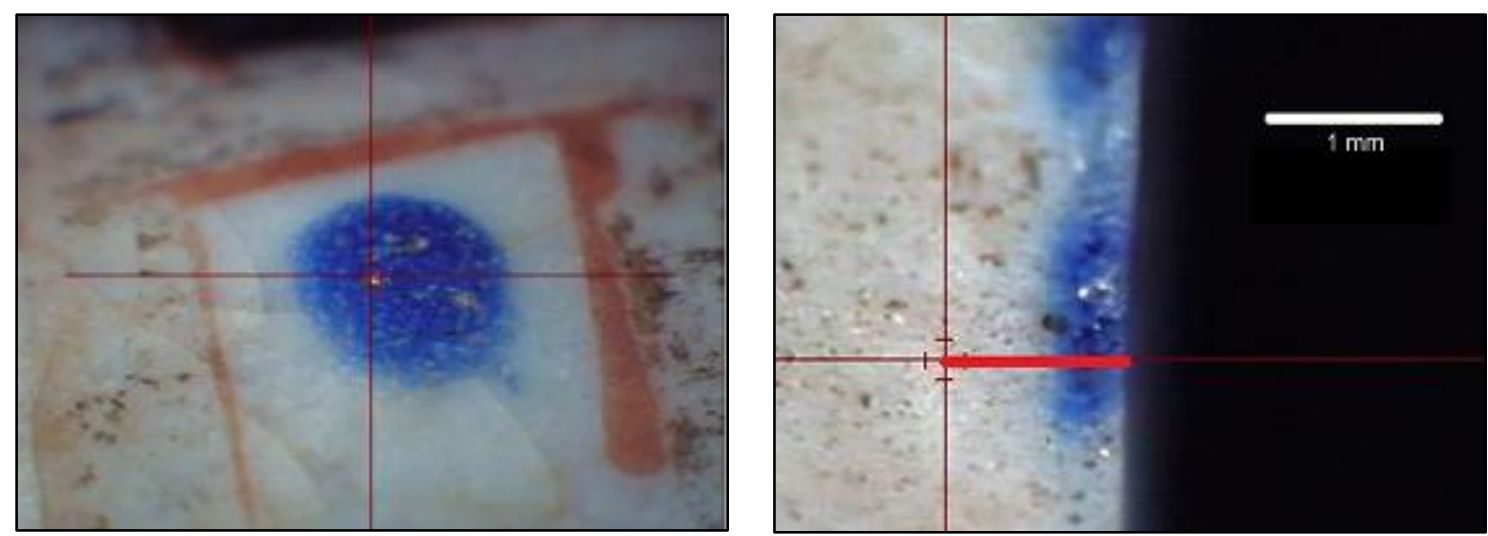

شكل ^\. تصوير روبرو و مقطع لعاب به همراه رنى آبى و قرمز، اسكن از مقطع لعاب براى نشان دادن ميزان عناصر از سطح به طرف

عمق [31].

Fig. 18: The blue pattern, the linear scan examination for a Chinese Yuan blue-and-white.

يايه به نوشتههاى باقى مانده از ابوالقاسم كاشانى مراجعه شده و نتايج آزمايشها با اين نوشتار مورد مقايسـه قـرار كرفته است.

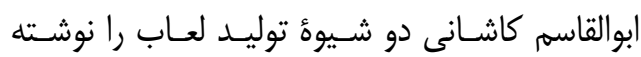

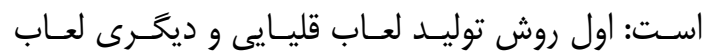

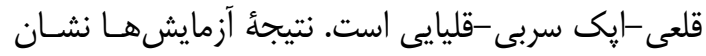

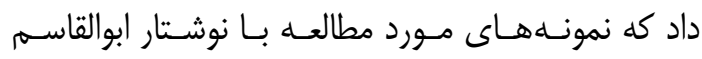

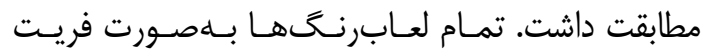
عمل آورى شده و سبس اجـرا شـــه بـوده اسـت. نتـايج شناخت رنحَها به اين صورت است: هماتيت براى رنغ إنى

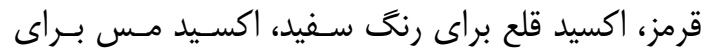

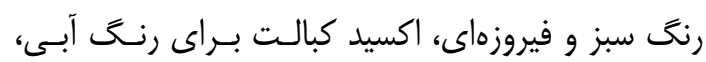

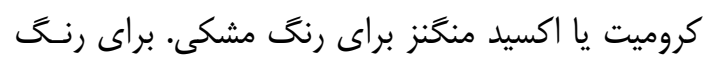
صورتى و قهوهاى از رنخ تركيبى اسـتفاده شـــه اسـت: هماتيت با اكسيد قلع براى رنغ صـورتى و هماتيـت بـاــا كروميت يا منغَنز براى رنغى قهوهاى استفاده شده است. بيشترين تغيير غلظت مربوط به كلسيه و كبالت است كه

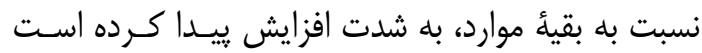

يكى ديخر از تكنيكهاى سفال لعابدار در ايـران در

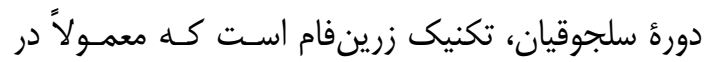

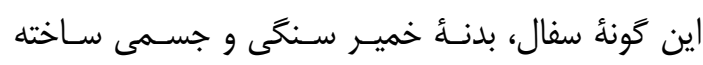

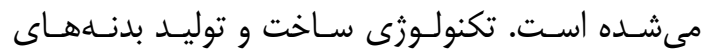
كلسنكى (Stonepaste) مربوط به كشور ايران و سوريه
SEM-EDS

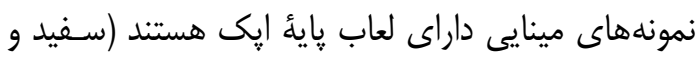

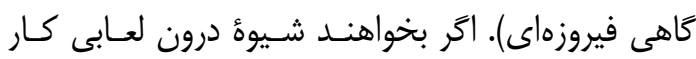

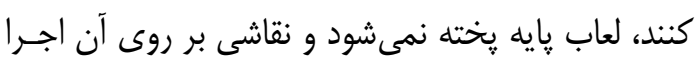

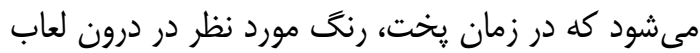

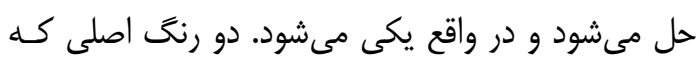

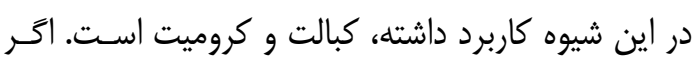

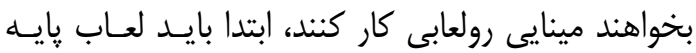

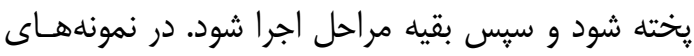

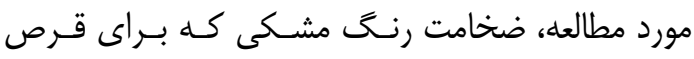
كردن طرح اجرا شده بوده، 19 ميكـرون تشـخيص داده

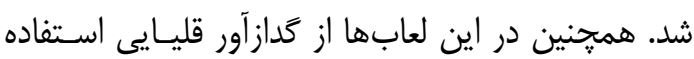

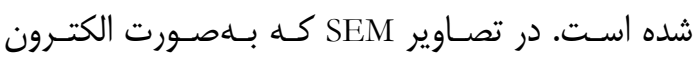

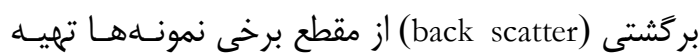

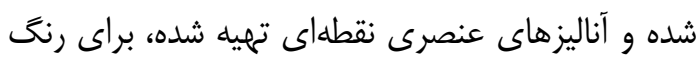
قرمز، هماتيت تشخيص داده شده و ضـخامت و ميـزان نفوذ آن در لعاب مورد بررسى قرار كرفته است] [30].

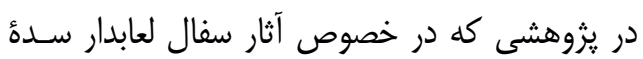

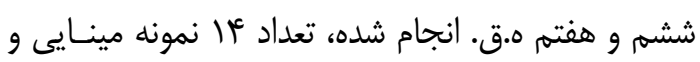
انمونه لاجوردينه از سايتهاى مختلف ايـران و مصـر

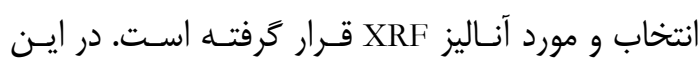

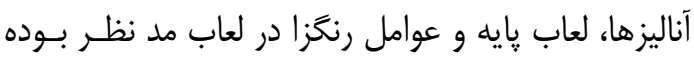
كه براى بررسى بهتر، تصاويرى از سطح نيز تهيـهـ شـده

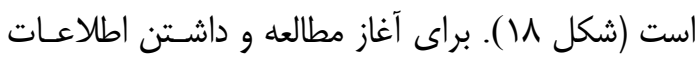




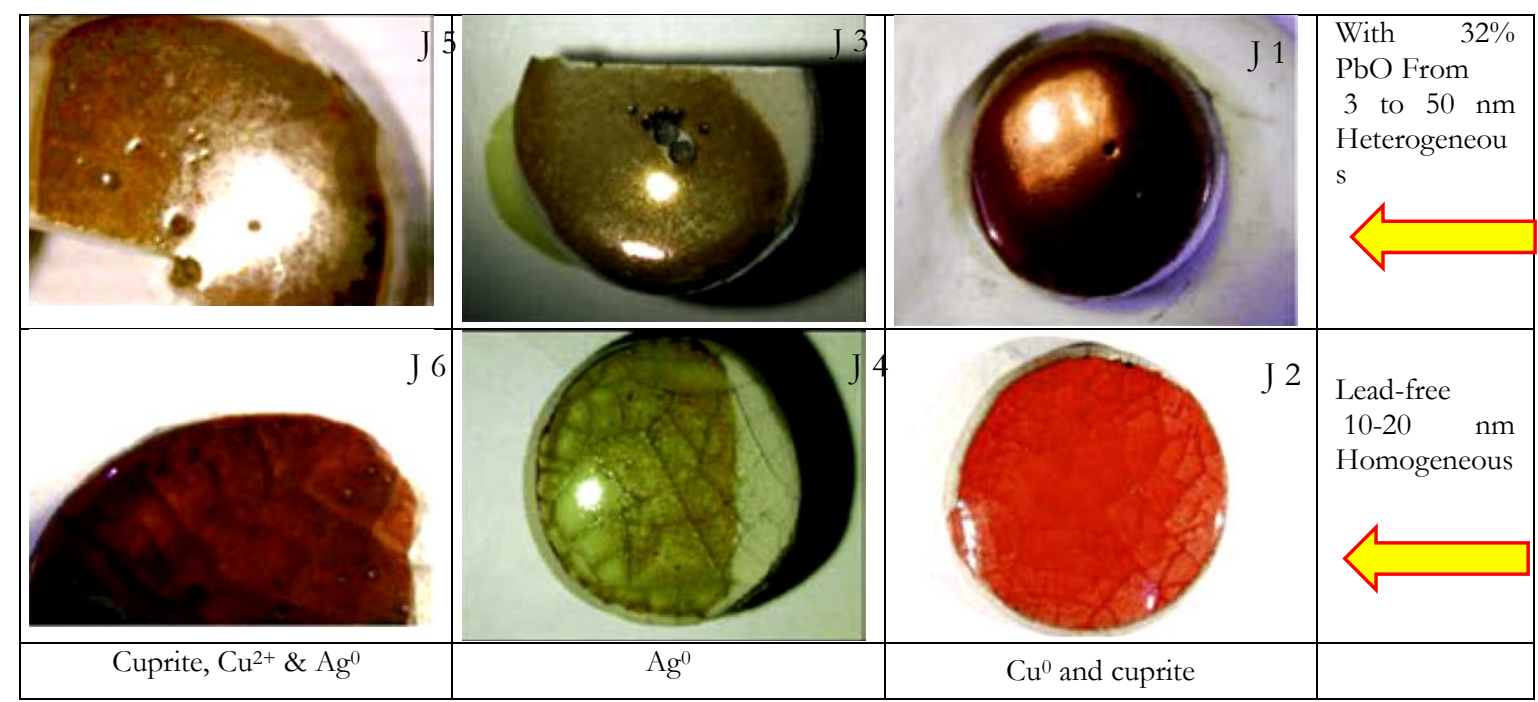

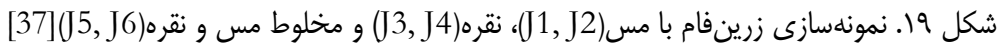

Fig. 19: Reproduction samples of copper (j1, j2), silver (j3, j4) and mixed copper and silver (j5, j6) lustres. The size and distribution of the nanoparticles was determined by SR-Micro-XRD, UV-vis spectroscopy and TEM

XANES; EXAFS; TEM)

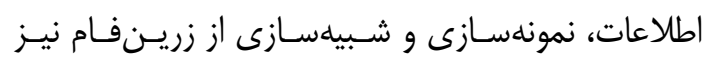
صورت پذيرفته است(شكل 19).

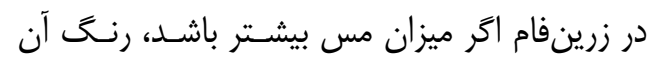

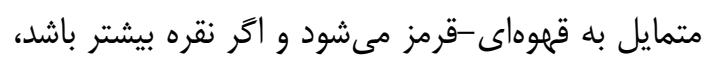

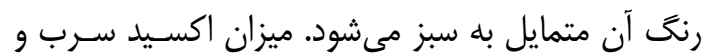

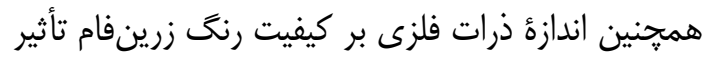

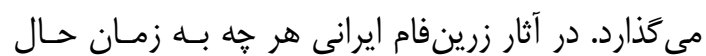

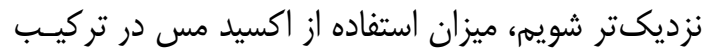

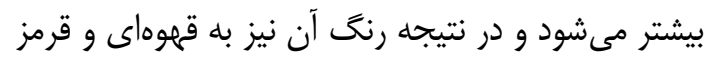
متمايلتر مىشود [37]. دستور توليد زرينفام متنوع است ولى جيزى كـه درد

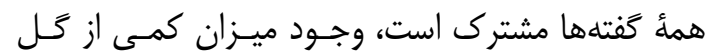

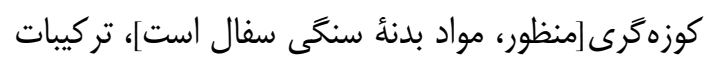

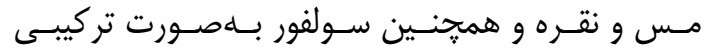

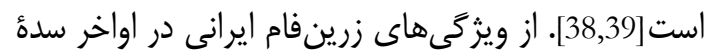
9.

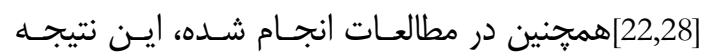
حاصل شده است كه در زرينفامهـاى قـرن هفـتم ه.ق. شنخرف نيز شناسايى شده است [40]. در يزوهشى كه موضوع آن زرينفامهاى آغازين دورهٔ اسلامى است، در بخشى از مطالعات، به آثار ايـران (اواخـر
در قرون ه و و ه.ق. است كه بـا لعـابهـاى مـات قلـع يوشش داده مى شـده اسـت[24,32,33]. طبـق مطالعـات

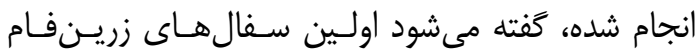
اسلامى مربوط به بصره عراق است كه در ســده س ه.ق. توليد شده است[28].

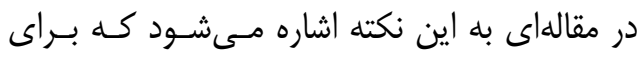

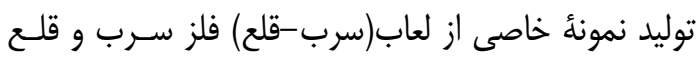

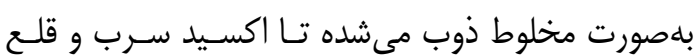
بهدست آيد. اين شيوهُ ساخت لعاب مربوط به ايران است.

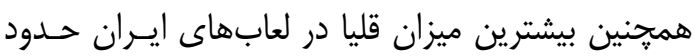

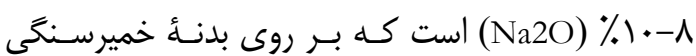
استفاده مىشده است[32]. زرينفام، يك لائُ نازك نانوكاميوزيت شيشه-فلز از نانوذرات فلز مس و نقره اسـت كـه در بسـتر شيشـهاى

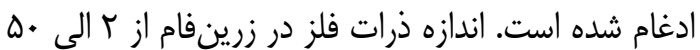

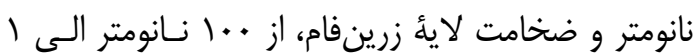
ميكرومتر متغير است[34,35]. زمانى كه اتمسفر كـوره در

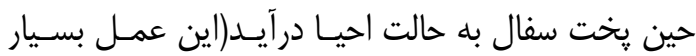

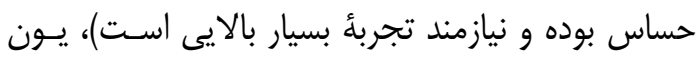

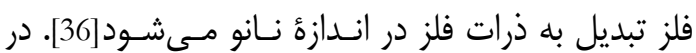

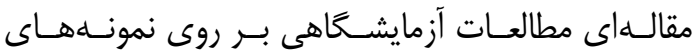

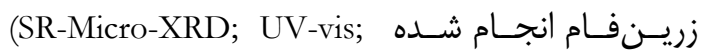


متعلق به قرن 9 ه.ق.[43,44] با غناى تزئينى بـيش از حـد

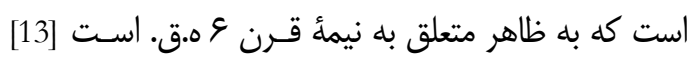

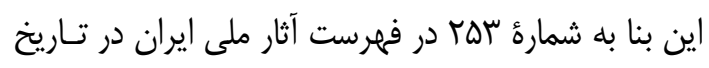

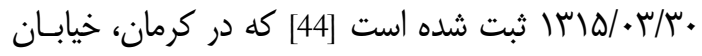

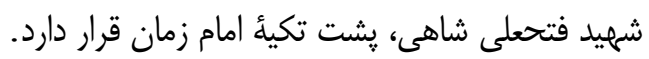

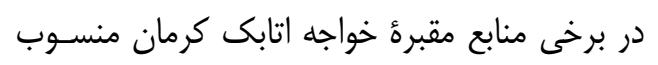

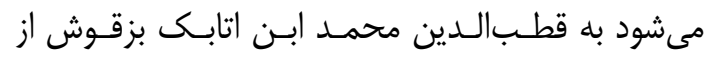

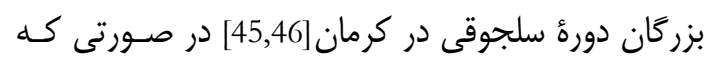

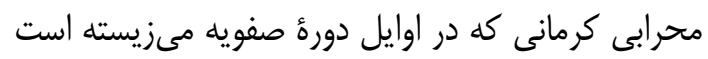
در كتاب مزارات كرمان اشـاره كـرده اسـت كـه مقبـره

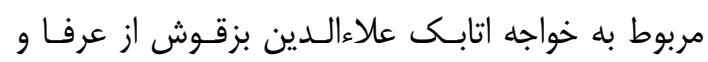

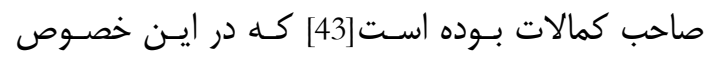

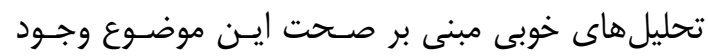

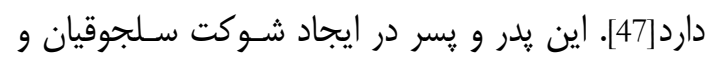
همجنين حكومت منطقة كرمان موثر بودهاند[48]. خواجه لـانه

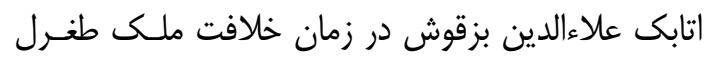

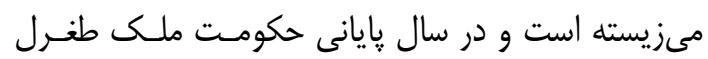

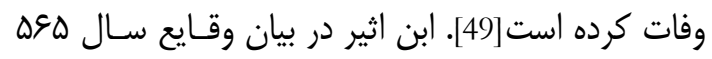

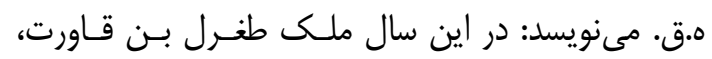

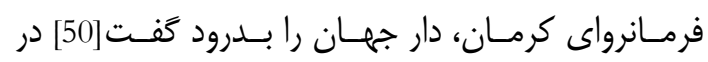

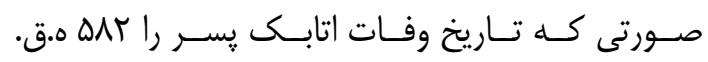
كفتنهاند[51].

با توجه به مطالعات انجـام شــده و شـواهد موجـود،

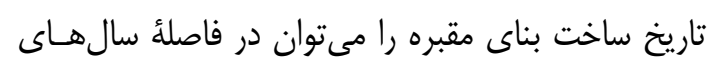

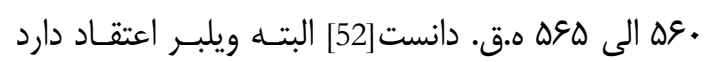
بناى خواجه اتابك احتمالاً تـاريخى در حسلدود • مسه ه.ق. داشته باشد[2].

اين بنا جزو اولين بناهـاى دورة اسـلامى در ايــران

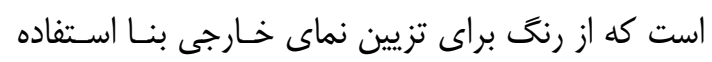

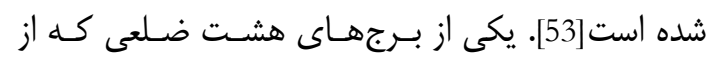
داخل جهار ضلعى است و وضعيت مربع داخلى نسبت بله

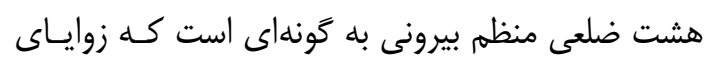

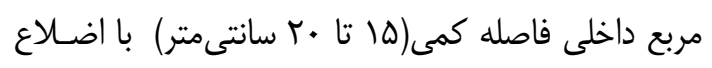

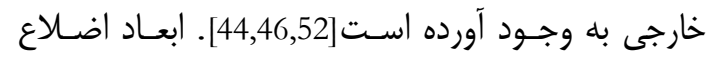

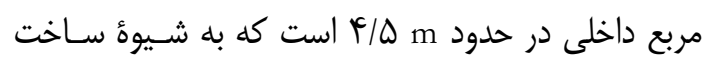
فيلبوش به فضاى گتنبدى تبديل شـده است(شـكل • ب).
سدة و و اوايل سدة V ه.ق.) يرداخته شـده كـه نمونـههـا مربوط به كاشان است. براى مطالعات و بررسىهاى دقيق لرداخت

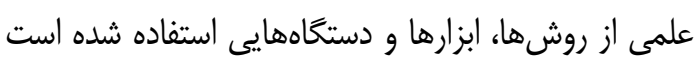

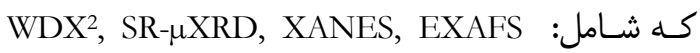

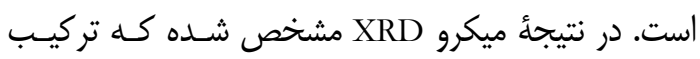

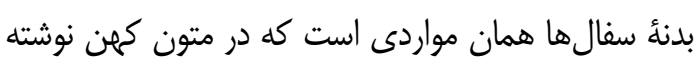

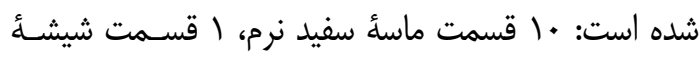

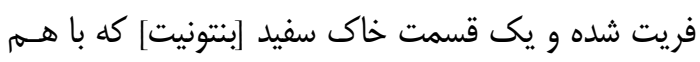

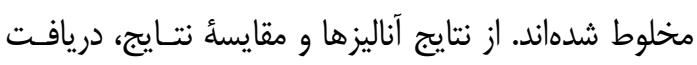
شد كه در حوزه تكنولوزى و توليد زرينفام، تأثير هنر ايران بر سوريه نمايان است؛ همجنين آثار ايران و اسيانيا بسـيار شبيه به هم است[41]]. در يزوهشى با ساخت نمونه هايى از زرينفام با رنت النى

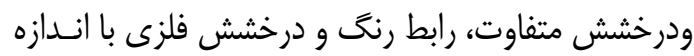
نانوذرات بررسى شدهاند. نتايج نشان داد كه در نمونـهـ بـاــا

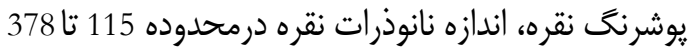
نانومتر بوده، اين ذرات كروى نبوده، تمام طول موجهاى نائ نازئ

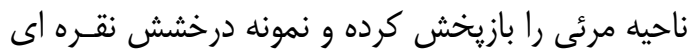

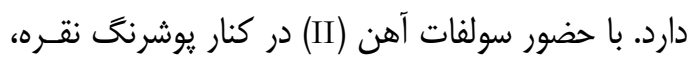

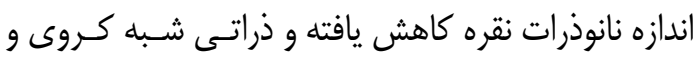

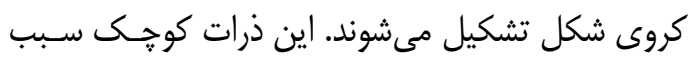

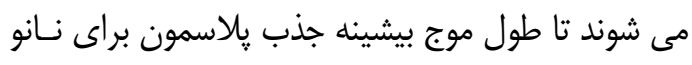

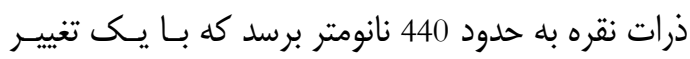

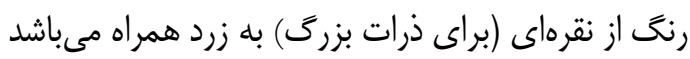

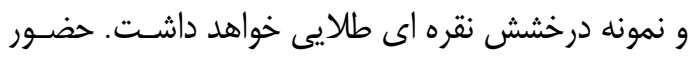
مس در يوشرنى زرين فام، باعث كاهش بيشتر اندازه نانو

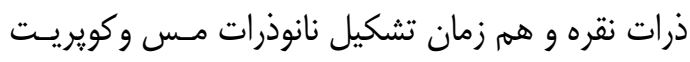

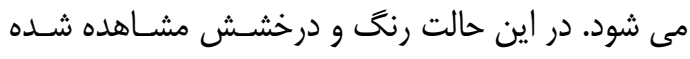

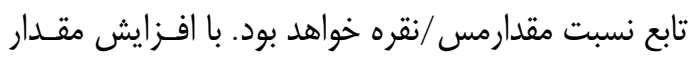
مس در يوشرنح، توزيع نانوذرات نقره فلزى را كنارذرات هارئم $\mathrm{Cu}_{2} \mathrm{O}$

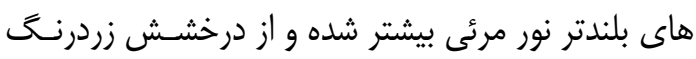
به درخشش قرمز مىرسيم [42].

ه. مقبره خواجه اتابك كر مان مقبره خواجه اتابك از مقابر برجى شكل عصر سـلجوقى و ومان 


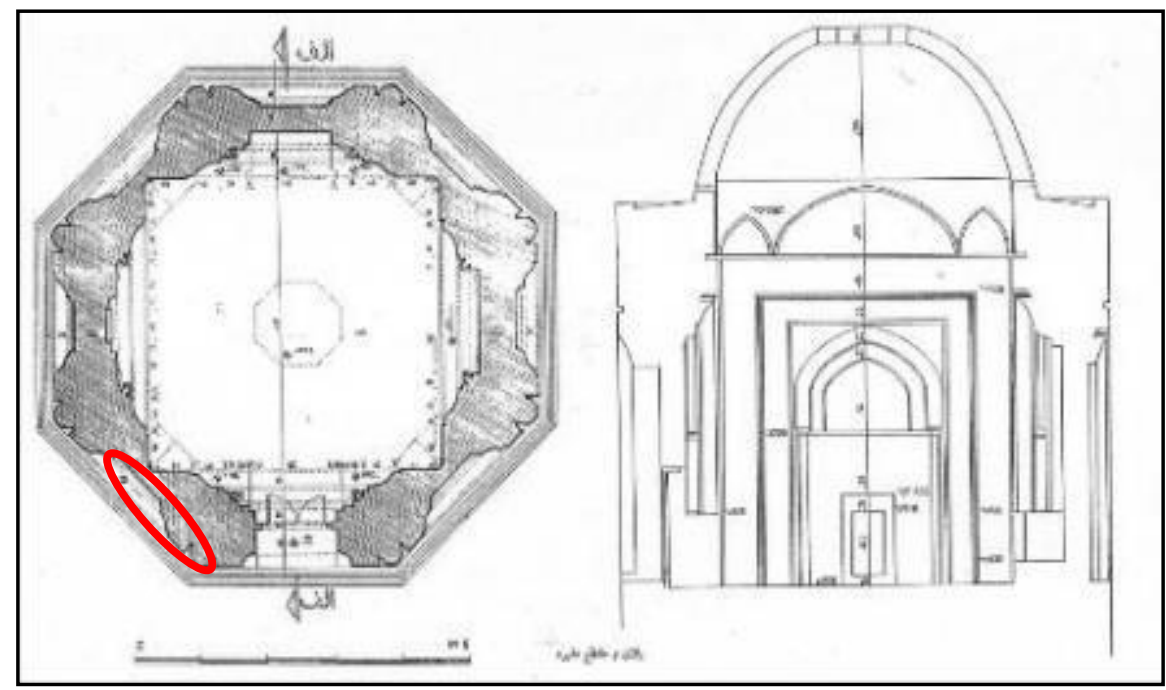

شكل •r. يُان و مقطع مقبرءٔ خواجه اتابك، رنخ قرمز مربوط به محل كاشىهاى تراش خورده در نماى بناست[54] Fig. 20: Psychograph and plan of Khaje Atabak mausoleum, Kerman, Iran

قديمى به اثر بركردد (شكل آآ. آرائُ داخلى بنـا تلفيـق

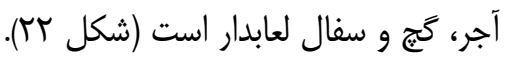

\section{ه- (. بر رسى متون علمى و تحليل نكَرش بر سفال لعابدار در بناى خواجه اتابك مون}

نسبت بله بسيارى از بناهـاى شـاخص دورهُ سـلجوقى در

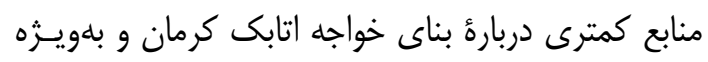

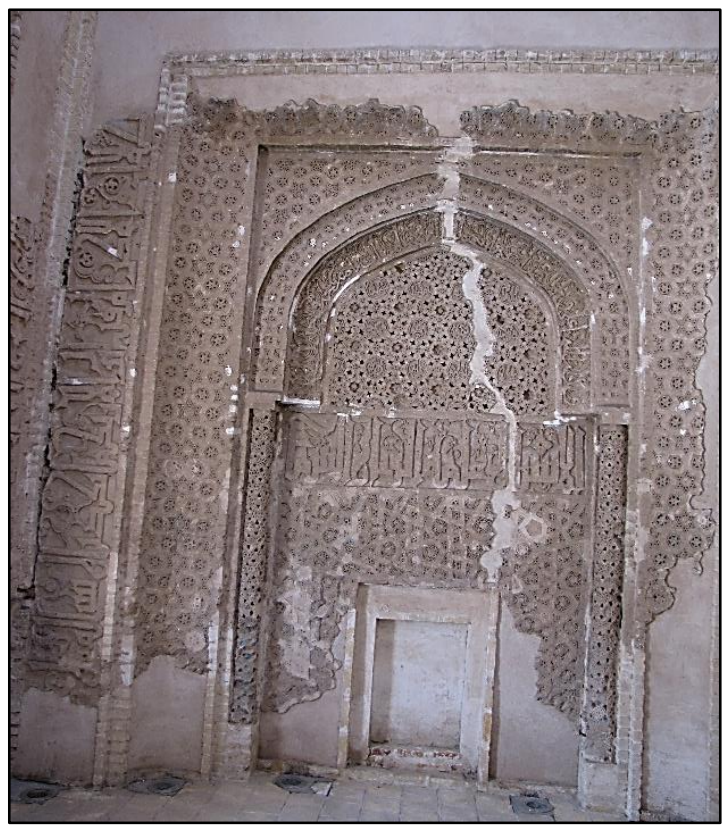

شكل بr. آرائٔ معمارى ضلع محراب، مقبره خواجه اتابك Fig. 22: Interior architectural decoration of Monument
قسمت فيليوشها و سـقف ايـن بنـا در سـالهــاى

كذشته بازسازى شده است. ابعاد آجرهايى كه اسكلت بنا

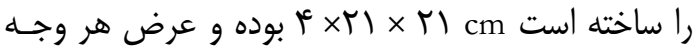
بيرونى حدود س متر است. لازم بهذكر است كه متأسـفانه

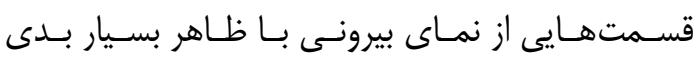

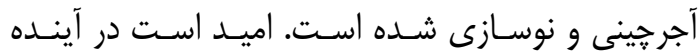

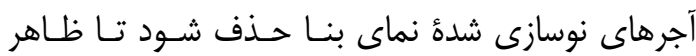

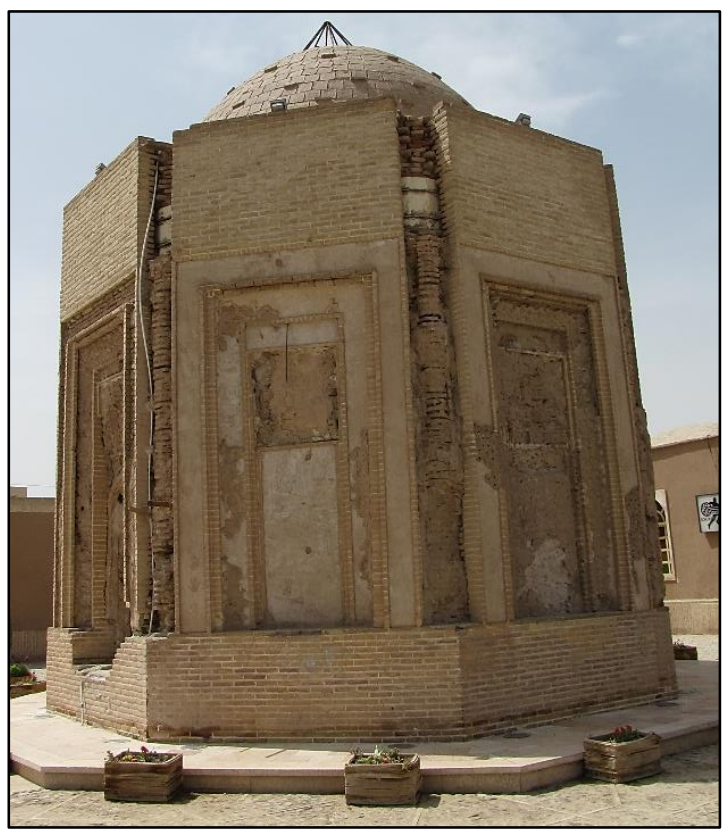

شكل آr. نماى جنوب شرقى مقبره خواجه اتابى كرمان

Fig. 21: Superficies of southeast Khaje Atabak mausoleum

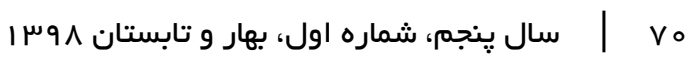


تشخيص همأ يزوهشكَران از سفال لعابدار، كاشى بـوده

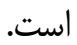

\section{ه-r. مراحل و فن اجراى آرايههاى معمارى}

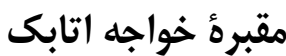

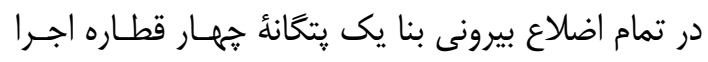

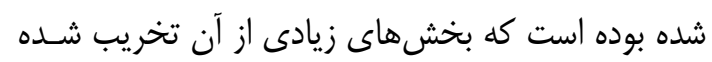

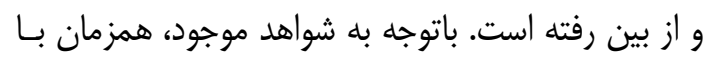

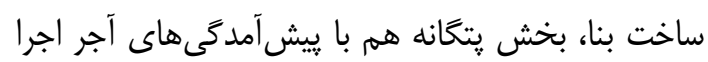

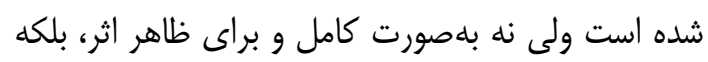

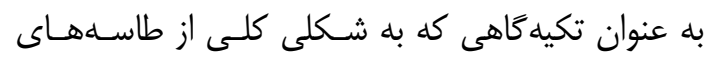

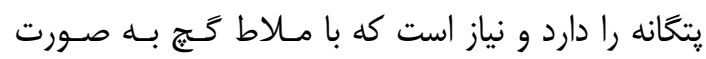

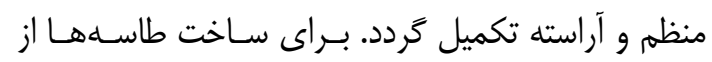

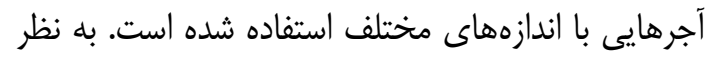

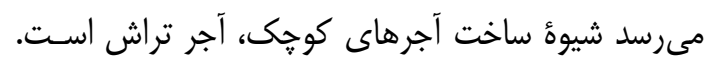

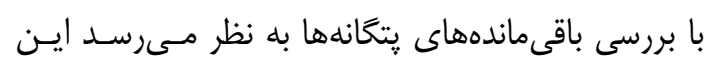

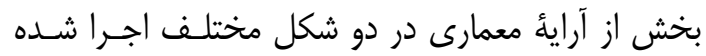

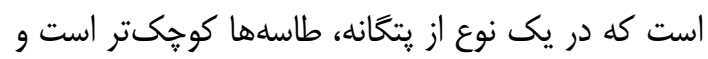

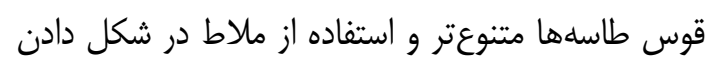
طاسهها بيشتر است. در ديخر شكل يتخانـه در ايـن بنـا،

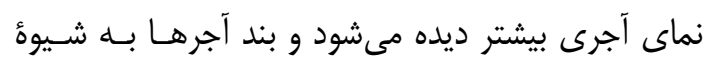

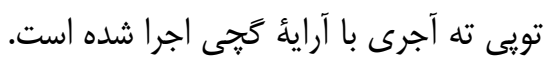

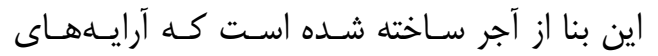

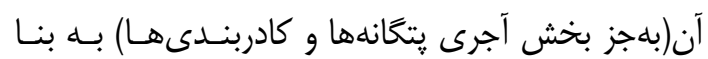

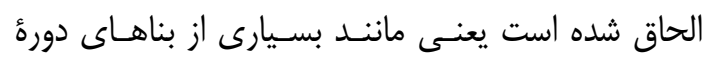
سلجوقى كه آرائُ آجرى همزمان با ساختار معمارى اجرا

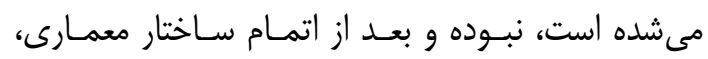

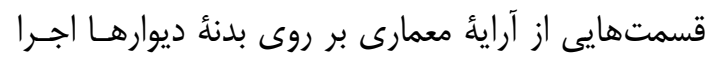

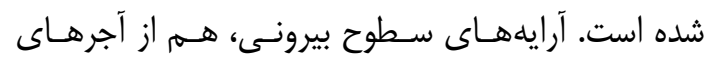

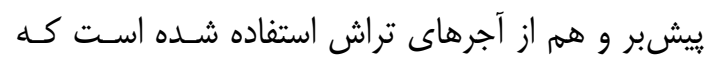

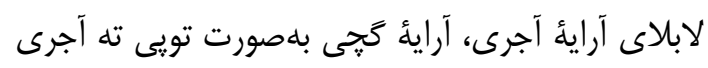
در شكلهاى مختلف اجرا شده است.

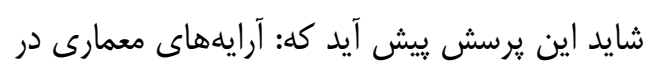

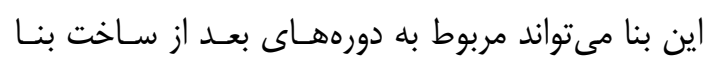
باشد؟ در ياسخ به اين يرسش بايد بـــ ايسن نكتـه توجـهـ

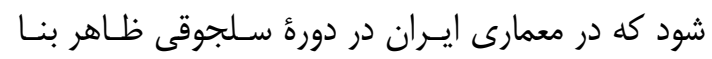

آرايههاى معمارى آن مطالب مفيدى را ارائه نمودهاند. در

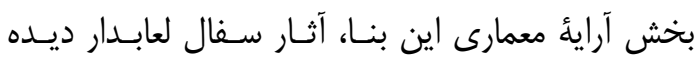

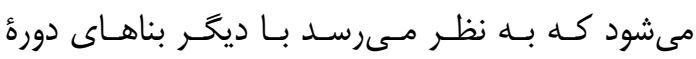

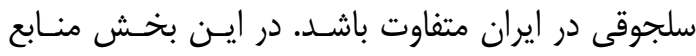

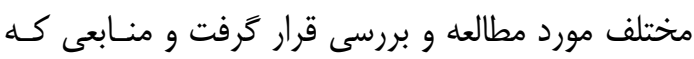
به سفال لعابدار در اين بنا اشاره كرده بودند ارائه خواهد

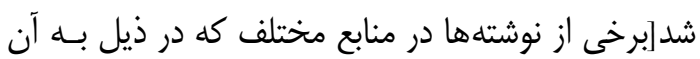
اشاره مىشود، مورد يذيرش نظارنده نيست]

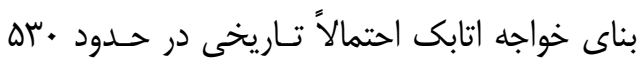
0.ق. داشته باشد كه در نقاط مركزى نقوش همه سطوح،

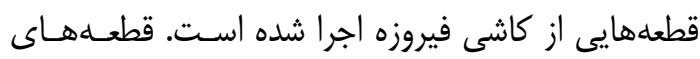

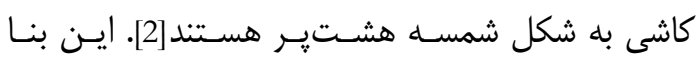

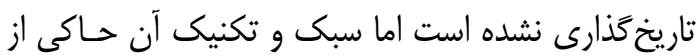

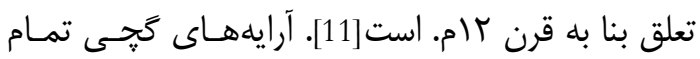

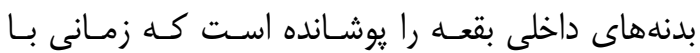
ستارههاى كوجگ، لوزى ها و مثلثهاى كاشى فيروزهاى

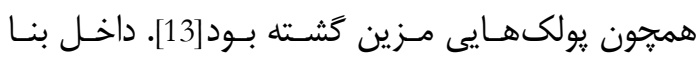

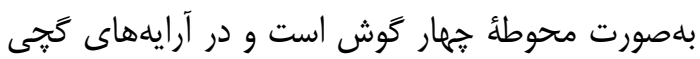

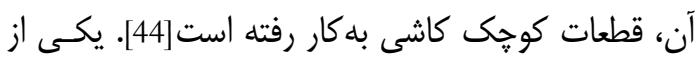

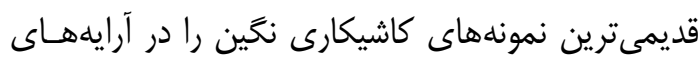
معمارى خواجه اتابك مىتوان مشاهده كرد [53].

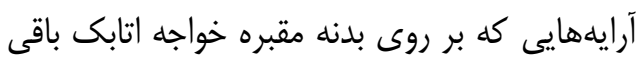

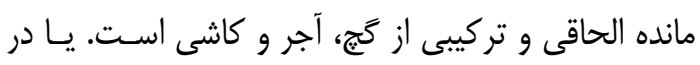

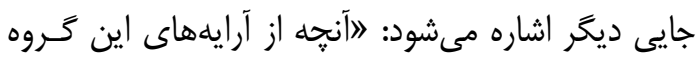

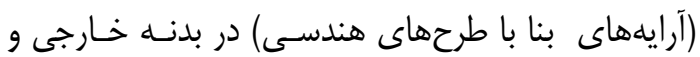

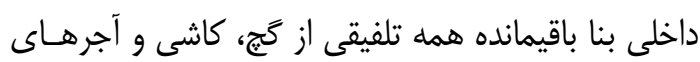

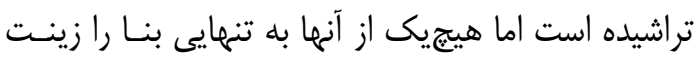

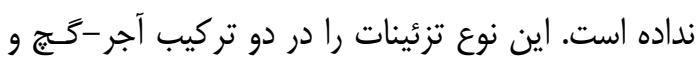
يا آجر-كج-كاشى مىتوان ديد《[54].

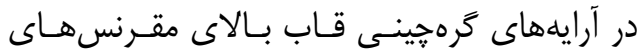

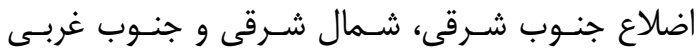

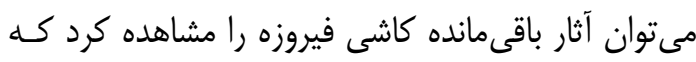
در ميان رنى اكر زمينه با درخشش خود جلوه خاصى به

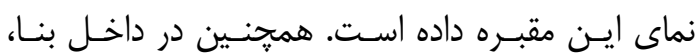

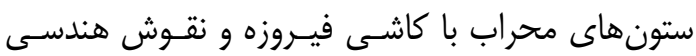

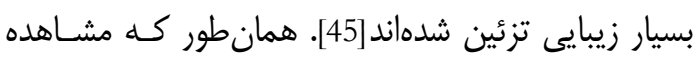

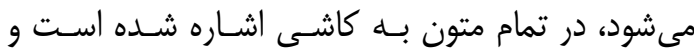


قطعات سفال لعابدار قرار مى گرفته كـه هـس از نصـب، در

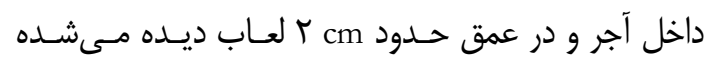

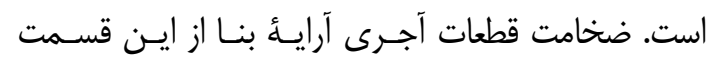

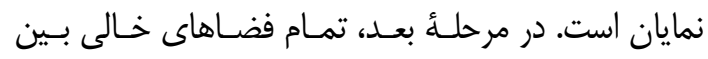

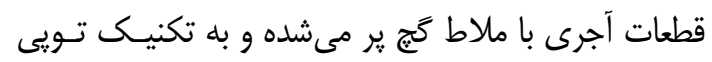

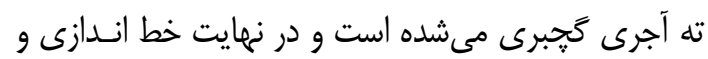

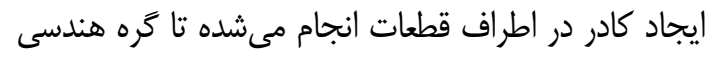

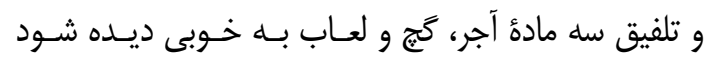

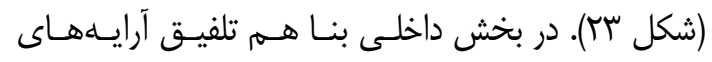

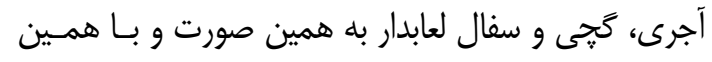

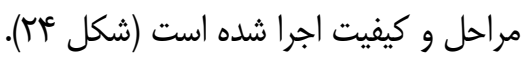

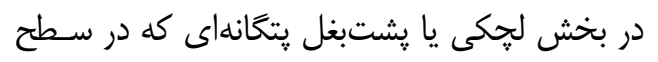

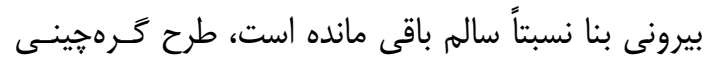
سادهاى با تلفيق آجر، كج و سفال لعابدار اجرا شده است.

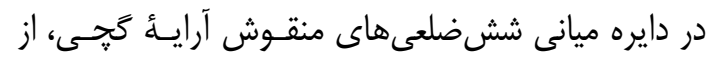

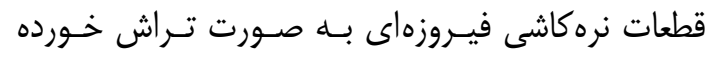

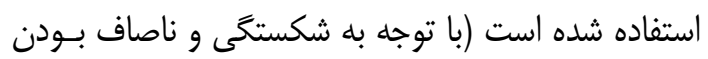

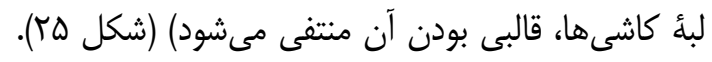

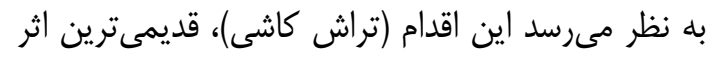

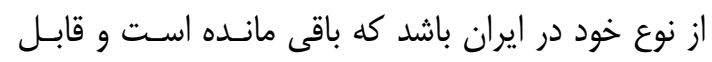

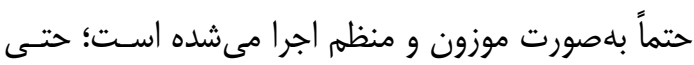
اخر قرار بوده نماى ساختمان بدون آرايـهـ و كتيبـه اجـرا

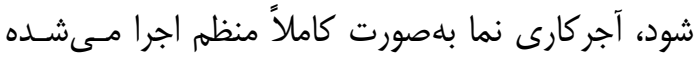

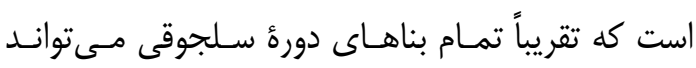
مثالى براى اين ادعا باشـــ. يعنسى قبــلـ از اينكــهـ معمـار

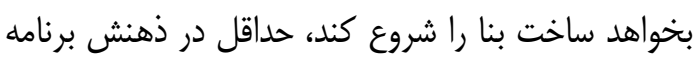

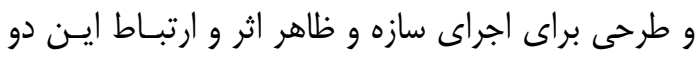

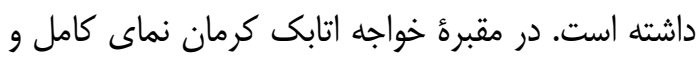

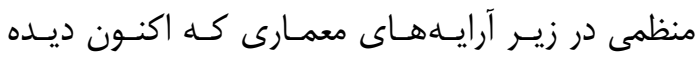

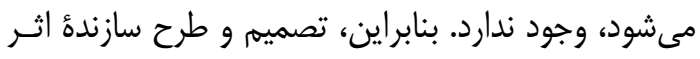

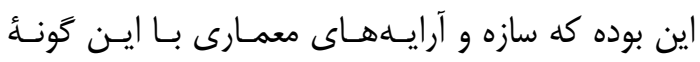

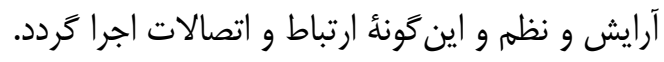

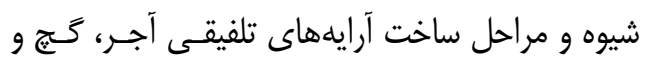
سفال لعابدار به اين صورت بوده كه ابتدا طـرح نقــوش يــا كره هندسى تهيه و بر سطح ديوار منتقل مى شـــه اسـت.

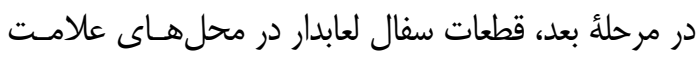

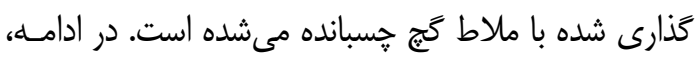

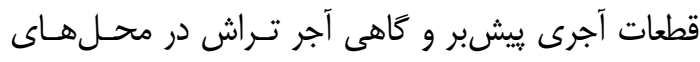

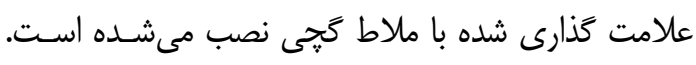

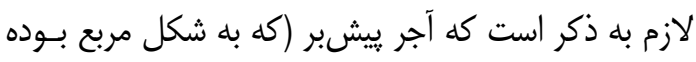

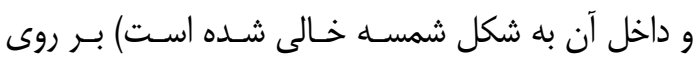
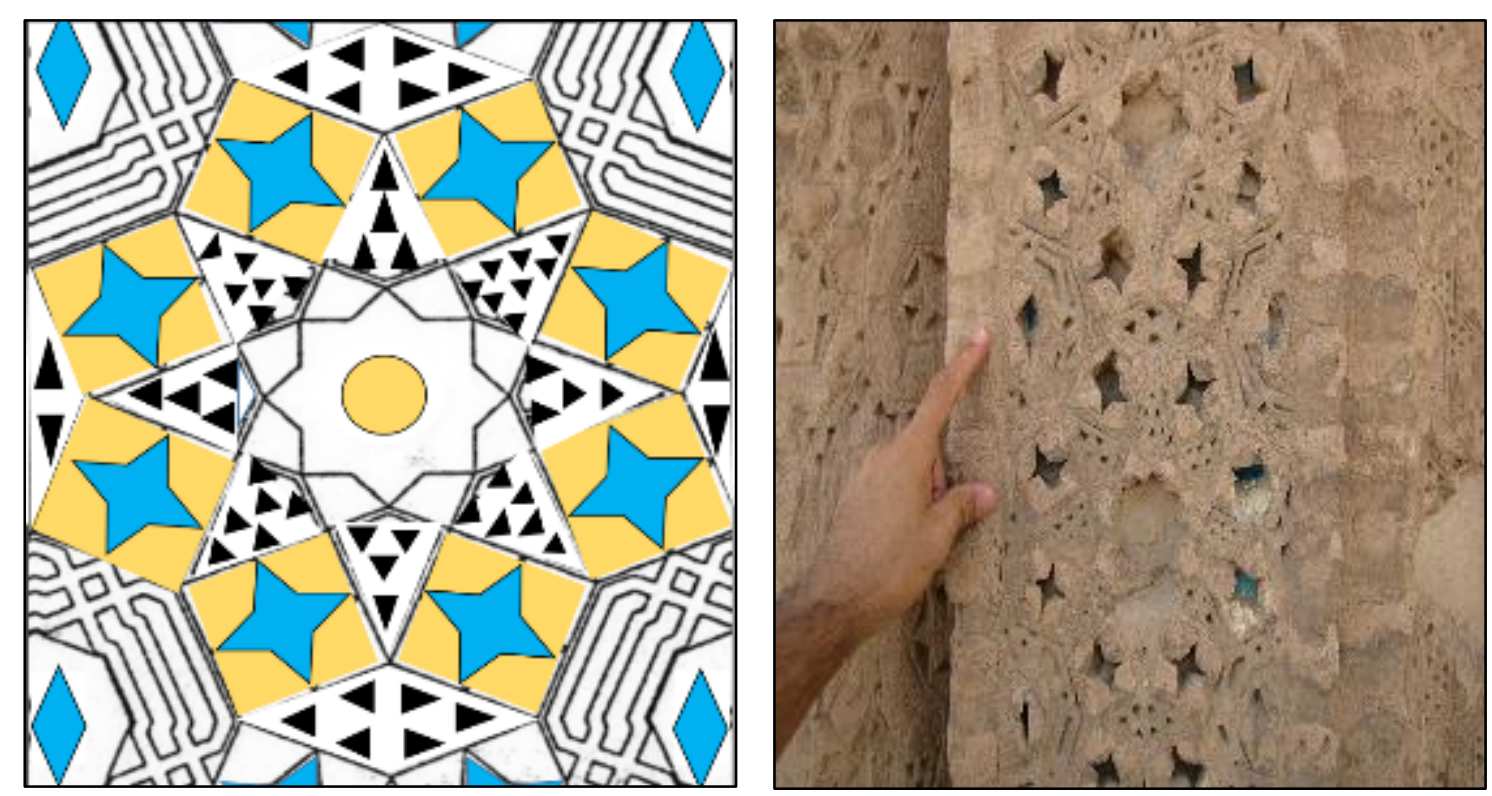

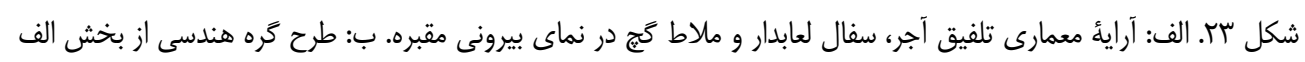
Fig. 23: Exterior architectural decoration of Khaje Atabak mausoleum, Kerman 

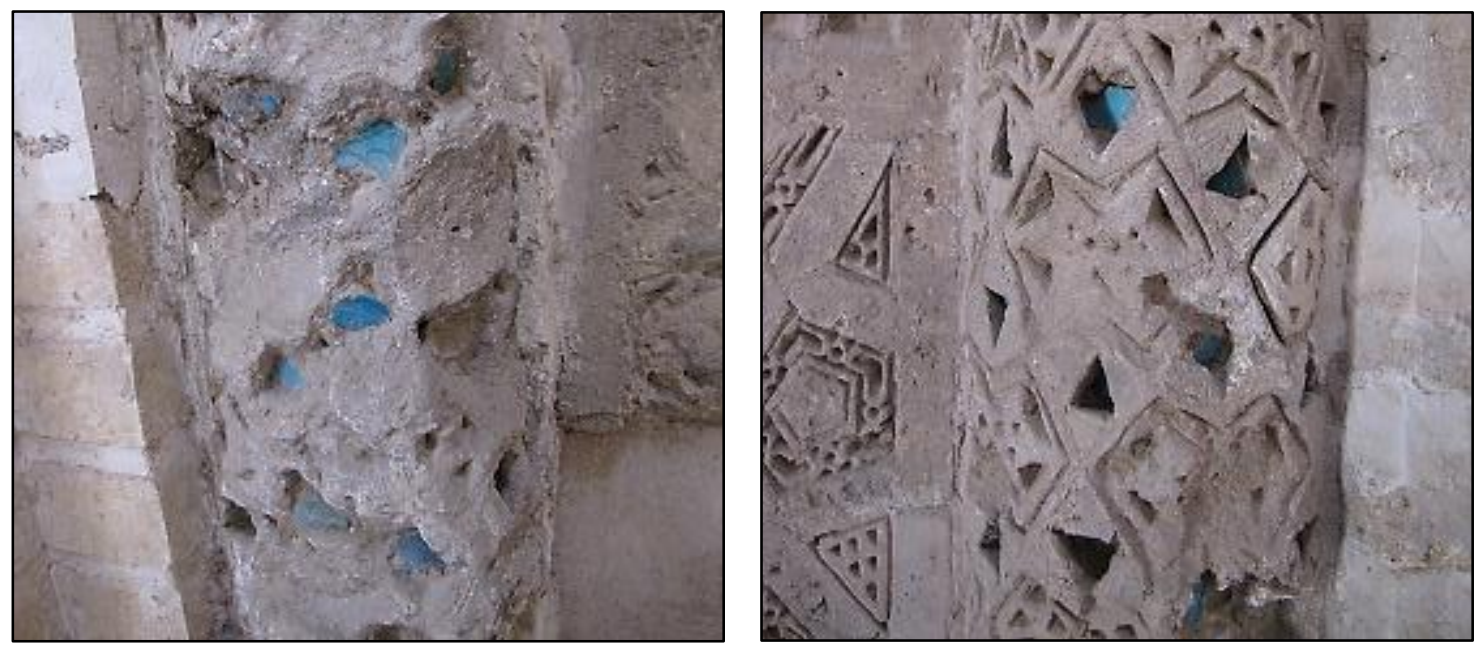

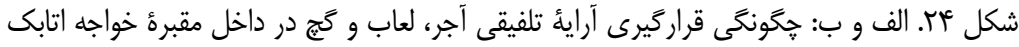

Fig. 24: Interior architectural decoration of Khaje Atabak mausoleum, Kerman

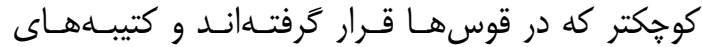

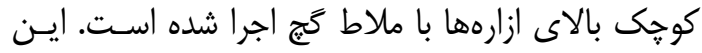

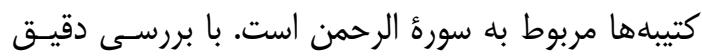

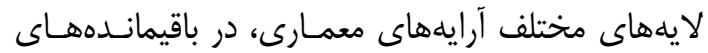

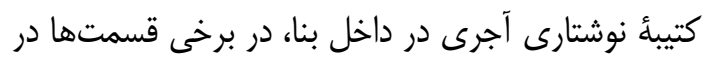

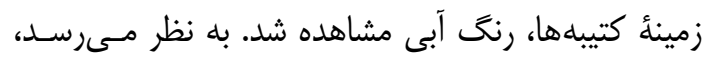
آرايههاى كَّى هم رنحَآميزى شده بودهاند كه نيـاز بـهـ

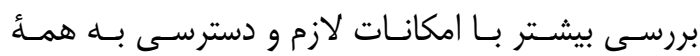
قسمتهاى بنا به كمى داربست است.

\section{ه-ب. كاشى يا قطعات شكستةُ ظروف سفالى}

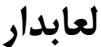

در آرايههاى معمارى سطوح بيرونى و همجنـين داخلى

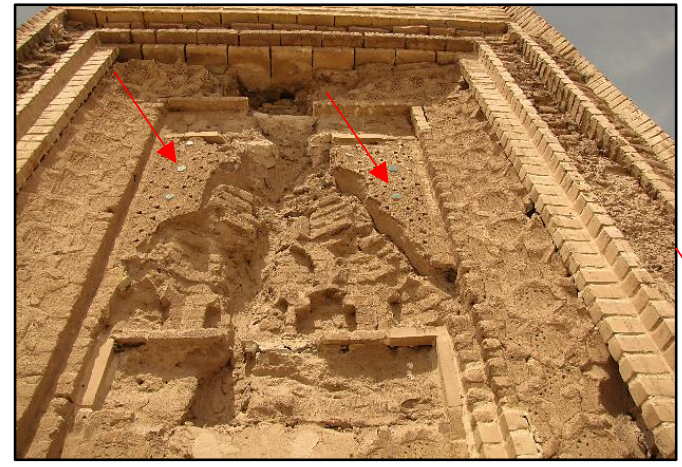

مشاهده و بررسى است. تا قبل از اين تاريخ، كاشىهـاى

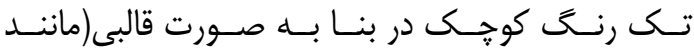
كاشىهاى مسجد حيدريئ قزوين) يا ييشبر بوده است. شايد تراش كاشى با تيشه به شكل دايره نامنظم كـه در

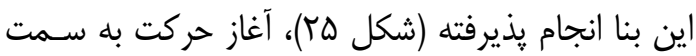

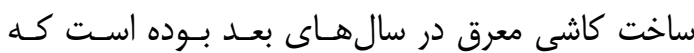
قطعات كاشى تراش مىخورده و كنار هم قرار مى گرفتـه تا شكل و نقش خاصى را بوجود آورد.

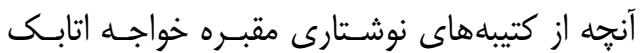

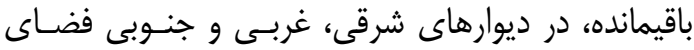
داخلى است. كتيبههاى بزرگتر كه در سطوح تخت اجرا

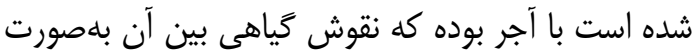

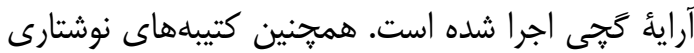

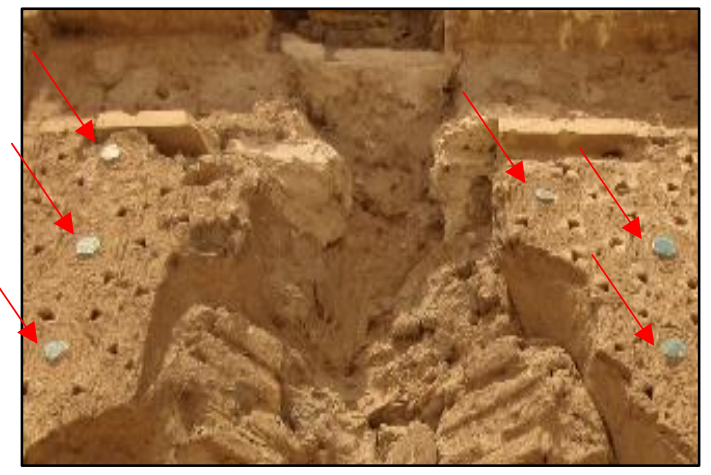

شكل ها. نره كاشىهاى تراش خورده به شكل دايره در نماى بيرونى مقبره خواجه اتابك

Fig. 25: Turquoise tiles in exterior Superficies of Khaje Atabak mausoleum, Kerman 

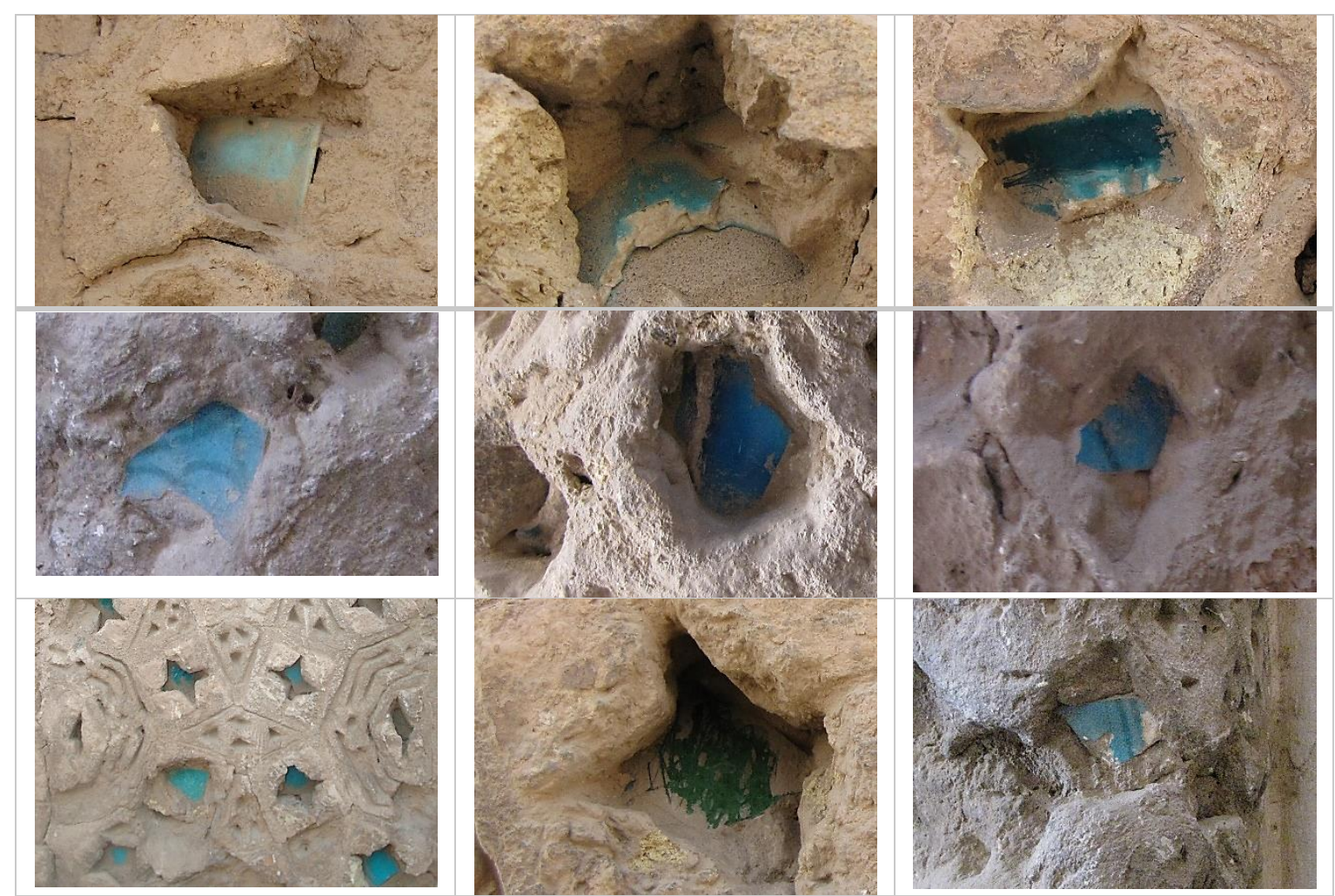

شكل צr. قطعات شكسته ظروف سفالى لعابدار كه در آرائُ معمارى مقبره خواجه اتابك بهجاى كاشى استفاده است

Fig. 26: Pieces of glazed Pottery (similar to tile) as an architectural decoration of Khaje Atabak mausoleum

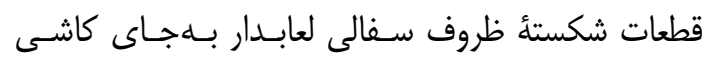

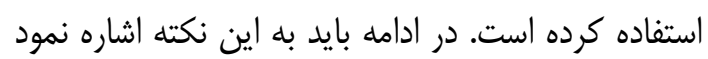
كه بقعُ خواجه اتابك كرمان قديمىترين بنـاى شـناخته

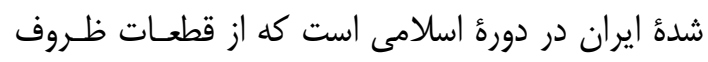

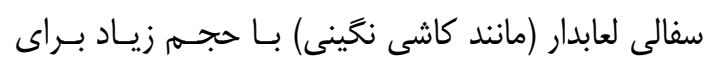

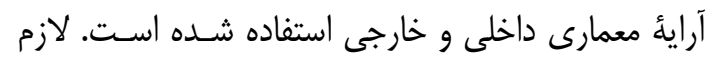

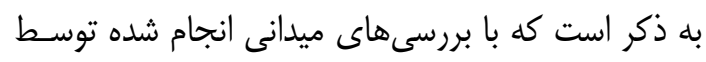

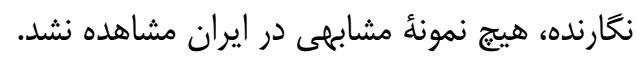

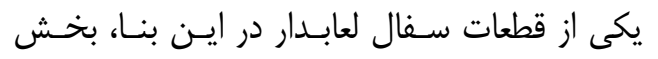

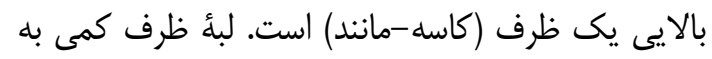

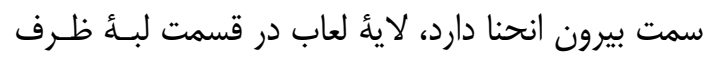

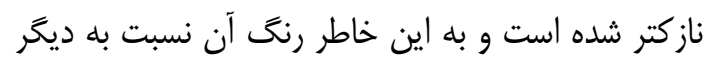
بخشهاى ظرف، روشنتـر اسـت. ايسن قطعـه از ظـرف

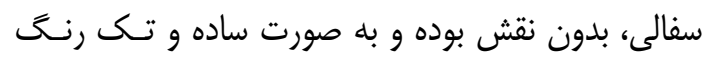
ديده مى شود(برخى از قطعات سفالى لعابدار در بدنه ديوار

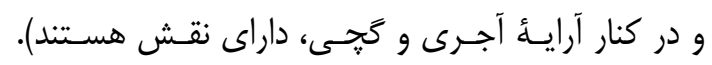

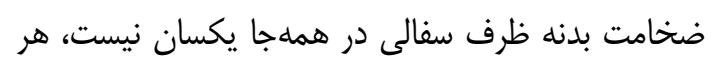

بنا، سفال لعابدار ديده مىشود. در تمامى متـونى كـهـ در

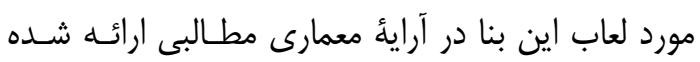

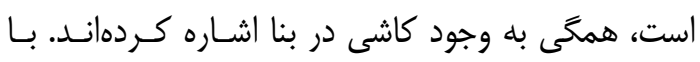

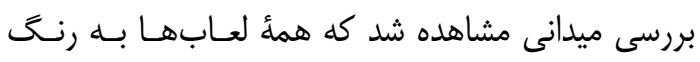

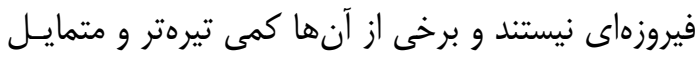

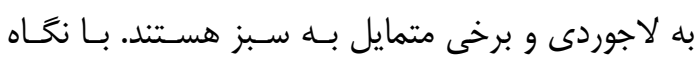

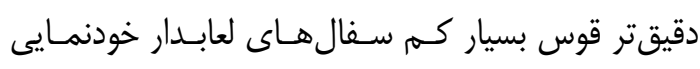

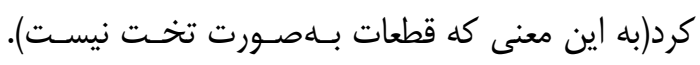

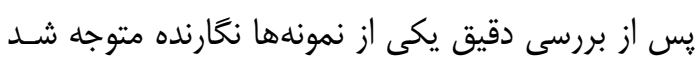

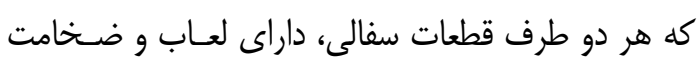
بدنئ سفال نسبت به كاشىهاى متداول آن دوره، بسـيار

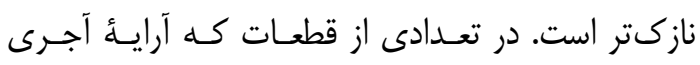

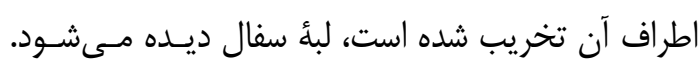

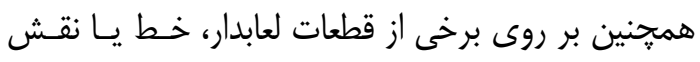
ديده مىشود (شكل سז، عآ و عץ).

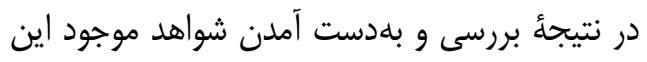

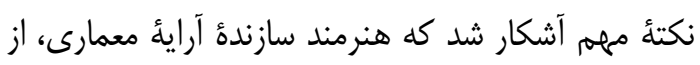



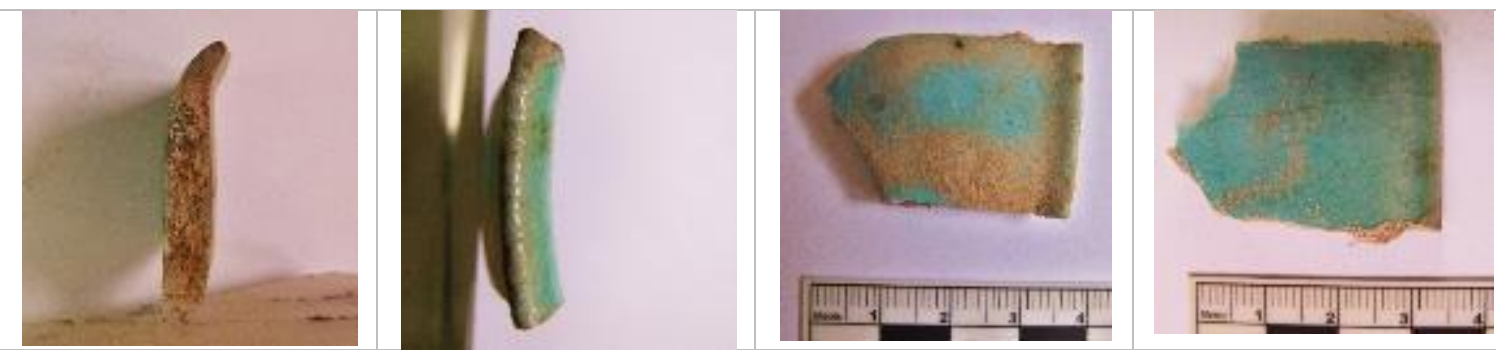

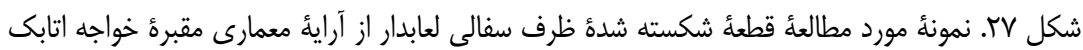

Fig. 27: Piece of broken glazed Pottery as an architectural decoration of Khaje Atabak mausoleum
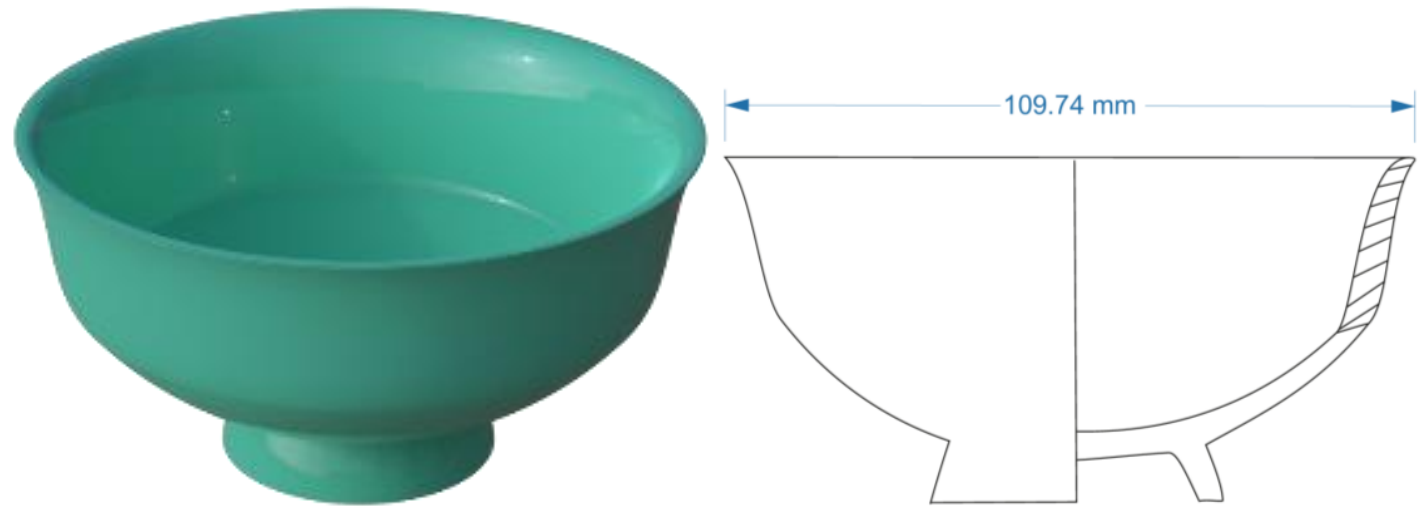

شكل ^r. طرحى دو بعدى و سه بعدى از ظرف سفالى با توجه به قطعه موجود(در شكل TV (T)

Fig. 28: Two and three-dimensional design of the earthenware container according to the existing piece

كه لايئ زيرين ديده مى شود. همرنين در قسمتهايى از لعاب، ريزترك مشاهده مىشود (شكل وج).

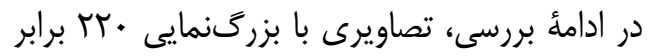

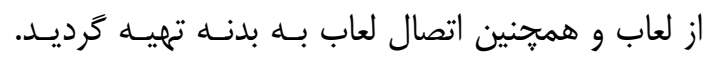

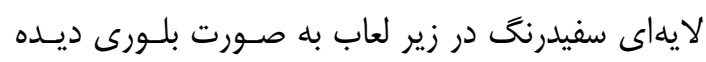

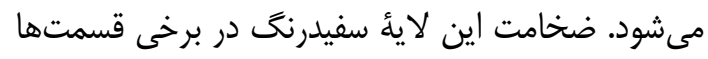

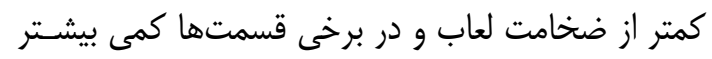

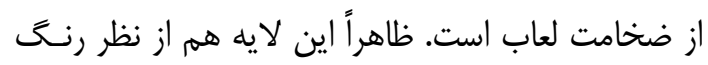

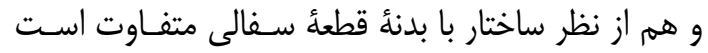

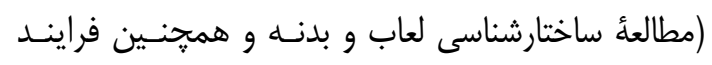

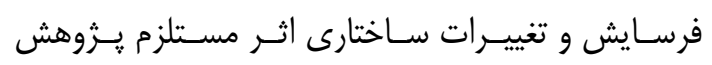

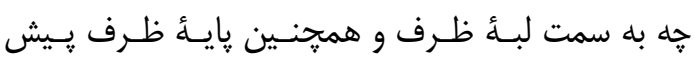

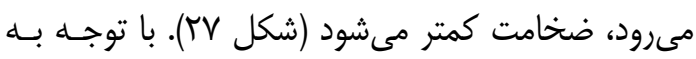

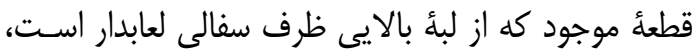

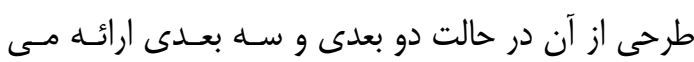
شود (شكل ^^ץ).

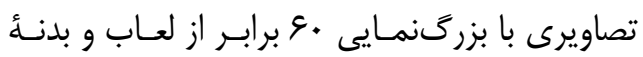
قطعه سفال مورد نظر (از سطح و مقطع شكسـته شــده)

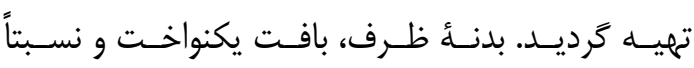
متخلخلى دارد. ضخامت لعاب در نمونسأه مـورد مطالعـاه،

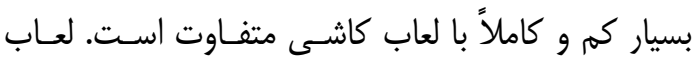

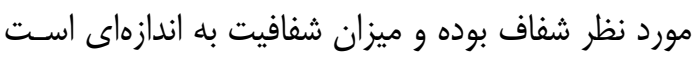
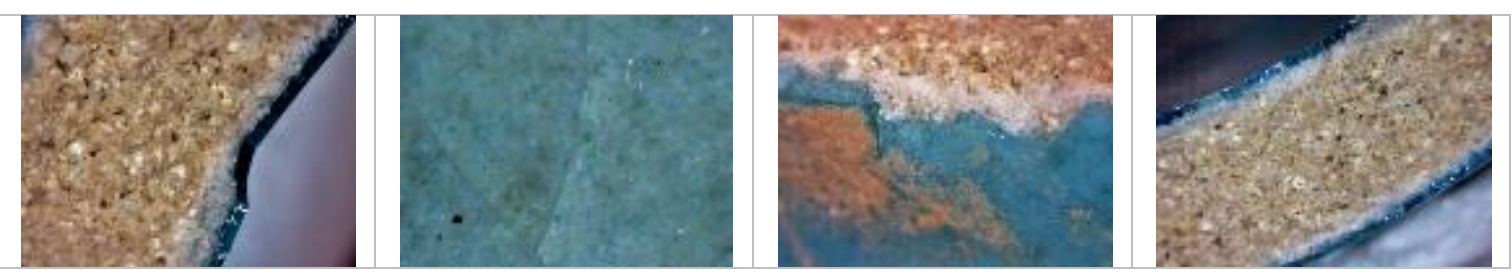

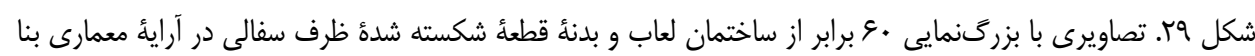
Fig. 29: Magnified pictures $60 \mathrm{X}$ of Piece of broken glazed Pottery as an architectural decoration

VQ

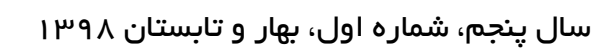



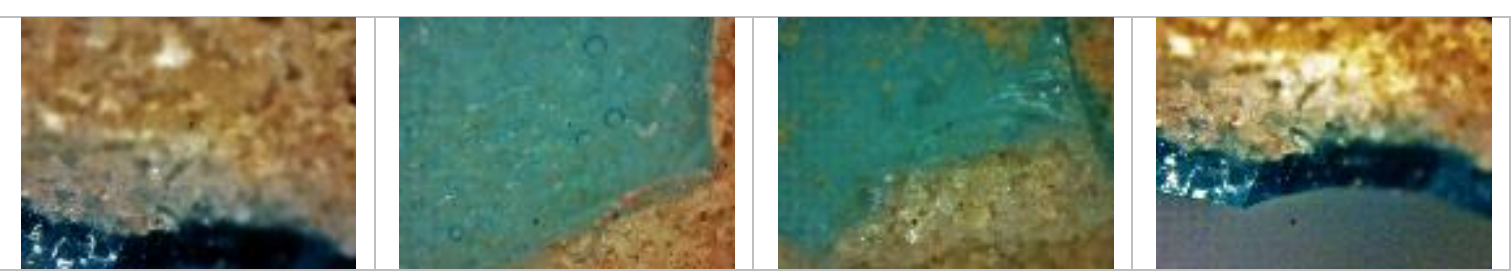

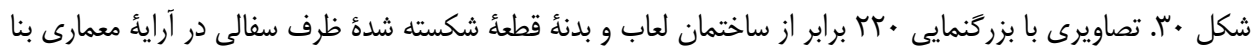
Fig. 30: Magnified pictures 220 X of Piece of broken glazed Pottery as an architectural decoration

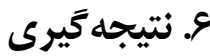

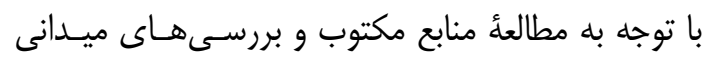

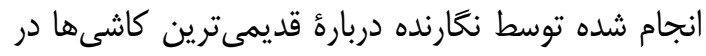

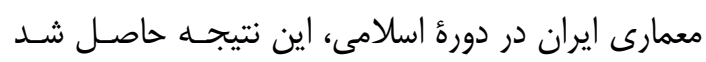

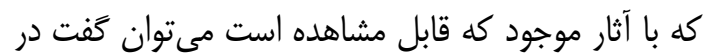

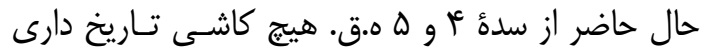

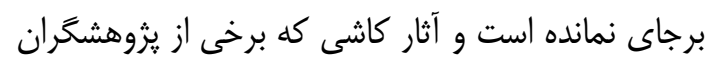

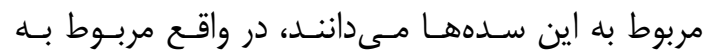

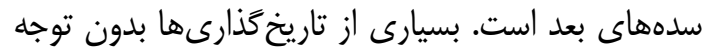

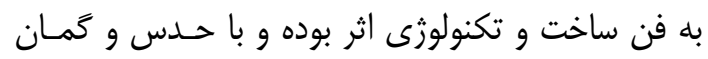
انجام شده است(كاشىهاى بدون تاريخ)، بنـابراين جـاى

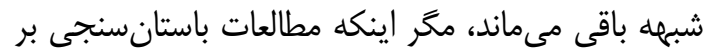
روى آنها انجام يذيرد.

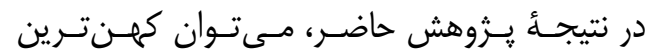

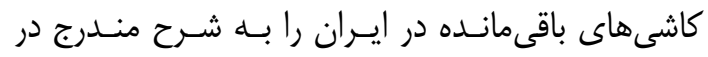
جدول زير معرفى نمود. در نتيجأ مطالعات ميدانى در مسجد جامع كليايعان،

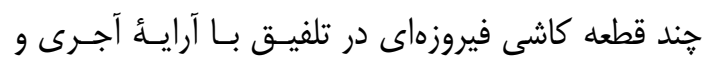

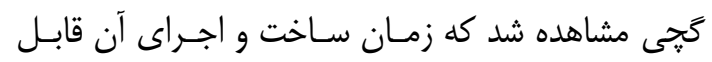

جداكانهاى است). همجنين استحكام لايـأُ سـفيد رنــ

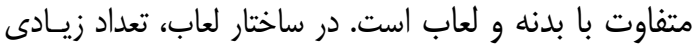

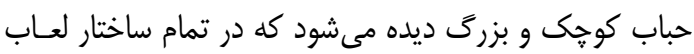

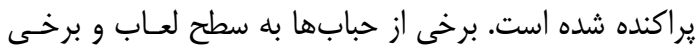
به بدنهُ قطعة سفالى نزديكتر است (شكل • • بر).

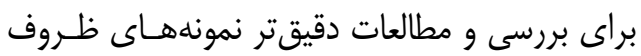

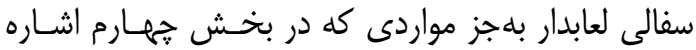
شد، مىتوان از ميكروييكسى نيز استفاده كرد، همانطور كه در مقالهاى با عنوان: ميكروييكسى روشى توانمند در

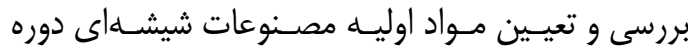

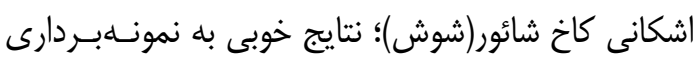

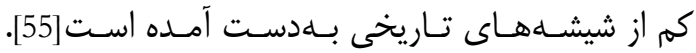

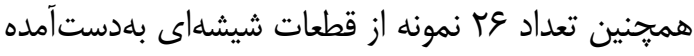

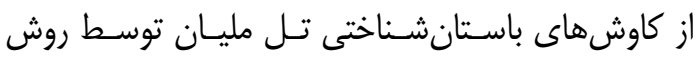

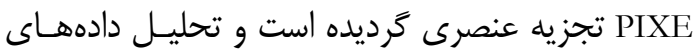

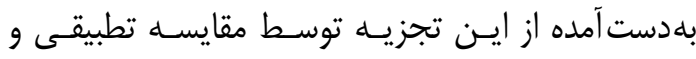

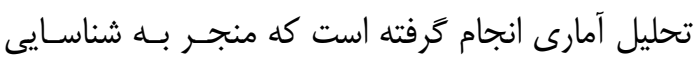
دستور ساخت و نوع منبع مورد استفاده جهت تهيه مـواد خام براى ساخت خمير شيشه شده است[56].

\begin{tabular}{|c|c|c|c|}
\hline محل تعلق & قدمت/تاريخ اثر & سفال لعابدار در معمارى ايران دوره اسلامى & رديف \\
\hline مسجد حيدريه قزوين & (ق. 0.9 & كاشىهاى تى رنى فيروزهاى و لاجوردى & 1 \\
\hline منارة مسجد سين اصفهان & 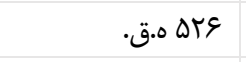 & نرهكاشى به رنگ فيروزهاى. كتيبه & r \\
\hline نغخهدارى در موزءٔ اسلامى برلين & 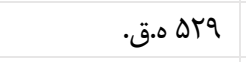 & كاشى زرينفام تاريخ دار & r \\
\hline مقبره خواجه اتابك كرمان & حدود • سه ه.ق. & بالف: قطره كاشى تراش خورده & r \\
\hline كَبند سرخ مراغه & 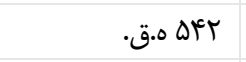 & كاشى تك رنغ فيروزهاى در تلفيق با آرائُ آجرى & $\Delta$ \\
\hline 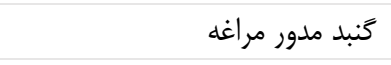 & 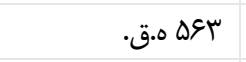 & كاشى تك رنى فيروزهاى در تلفيق با آرائُ آجرى & \& \\
\hline مناره مسجد جامع دامغان & احتمالاً سده ؟ ه.ق. & كاشىهاى نقشبرجسته تى رنغ & $\checkmark$ \\
\hline 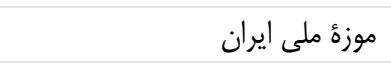 & احتمالاً سده ؟ ه.ق. & كاشى نقشبرجسته تك رنخ(كتيبه، محمد) & $\wedge$ \\
\hline بنا مربوط به سالهاى يوع الـى & اسلامى در ايران & ت و مىتواند جزو قديمىترين كاشىهـاى دوره & تأمل \\
\hline
\end{tabular}




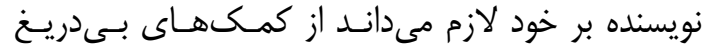

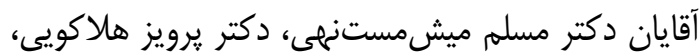

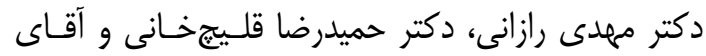

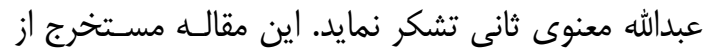

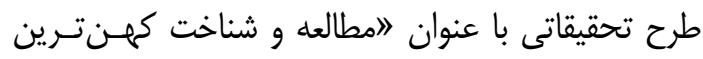

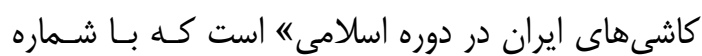

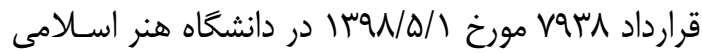
تبريز به پِايان رسيده است.

\section{يـنوشتها}

ا. اجراى نقـش بـر روى سـفال لعابــار بــا سـهـ شـيوه انجـام

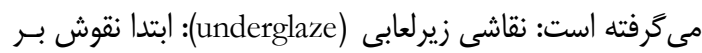

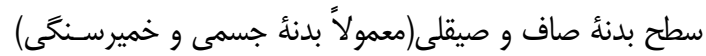

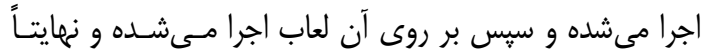

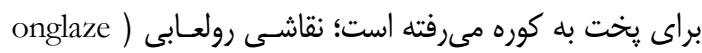
(or overglaze

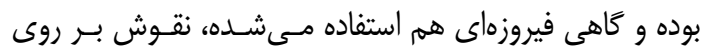

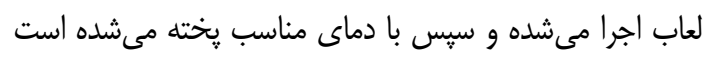

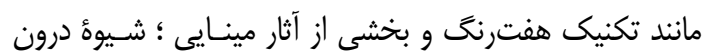

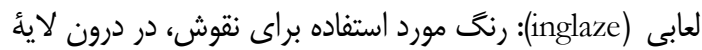

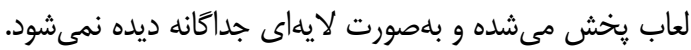
2. Cameca S-50 (WDX) Microprobe with experimental conditions of $1 \mathrm{~mm}$ spot size, $15 \mathrm{kV}$ and $10 \mathrm{nA}$ probe current except for $\mathrm{Na}$ and $\mathrm{K}$ for which the probe current was reduced to $1 \mathrm{nA}$ and the spot size increased to about $5 \mu \mathrm{m}$.

\section{References}

[1] Kashani AA. Arayes Aljavaher va Nafayes Alatayeb 1301. Tehran: Almaa; 2007.

[2] Wilber DN. The development of mosaic faience in Islamic architecture in Iran. Ars Islam 1939:16-47.

[3] Allan JW, (Oxford) AM. Medieval Middle Eastern Pottery. Ashmolean Museum Oxford; 1971.

[4] Ghandi S. The role of the tile in Iranian architecture. Vis Arts Stud 2003; 20:1836. [In Persian]

$$
\begin{aligned}
& \text { قتـــى سـياوش. نقـش كاشـى در معمـارى ايرانسى. }
\end{aligned}
$$

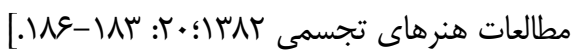

[5] Karl j D. Islamic Art In Architecture,

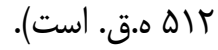

همجنين مىتوان كفت كهنترين كاشى با تكنيـى إنى

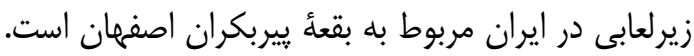

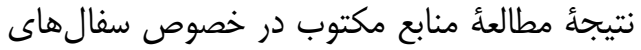

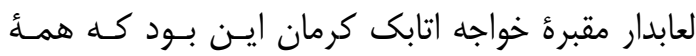

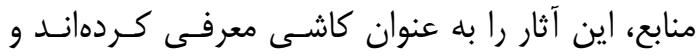
اشارهاى به قطعات شكستأ ظروف سفالى نشده اسـت.

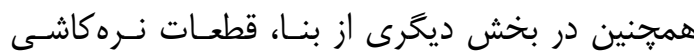

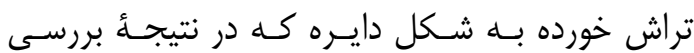

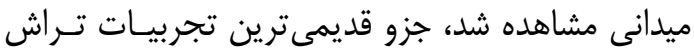

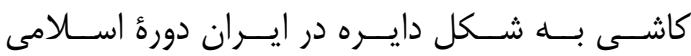
است(اقدامى كه بعدها در كاشى معرق انجام مى گرقفتـهـ

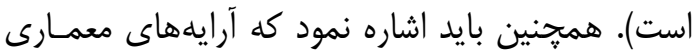

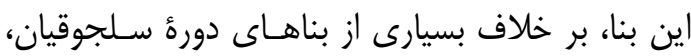
جداى از سازه معمارى و در مرحلهاى ديكر اجـرا شـده بـاه است. همجِنين در نتيجأ بررسىهاى ميدانى، در زمينــأ

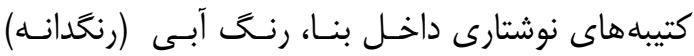

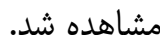
يكى از اصلىترين نتايج اين يثوهش، مربوط به كشف آنف

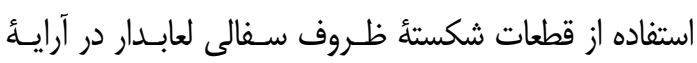

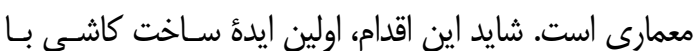
ضخامت كم براى آرائُ معمارى را شكل داده باشد.

\section{سياسگز ارى}

Tile, Metalworking, Knitting, Painting. (Translated by Basiri R.).Tehran: Farhangsara; 1984. [In Persian]

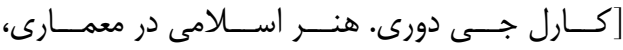

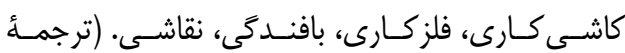
بصيرى رضا). تهران: فرهنگسرا؛ سوكسا.]

[6] Maheronaghsh M. Tile and its application. Tehran: Samt; 2002. [In Persian]

[ماهرالنقش محمود. كاشى و كاربرد آن. تهران: سمت؛

$[.1 \mathrm{r}$ N1]

[7] Bloom JM. Minaret: symbol of Islam. Oxford University Press Oxford; 1989. [n Persian] 
[8] Mehrpooya J. Traditional architecture arrays in mosques of Iran. Art J 1997; 33: 556-73. [In Persian]

$$
\begin{aligned}
& \text { [مهريويا جمشيد. آرايههاى معمارى سـنتى در مسـاجد }
\end{aligned}
$$

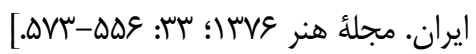

[9] Kiani M, Karimi F, Qouchani A. Introduction to the art of tiling in Iran. Tehran: Museum of the Reza Abbasi; 1983. [In Persian]

$$
\begin{aligned}
& \text { [كيانى محمديوسف، كريمى فاطمـه، قوجـانى عبـدالله. }
\end{aligned}
$$

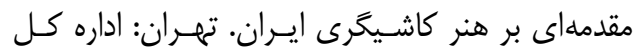

$$
\begin{aligned}
& \text { موزهها، موزهُ رضا عباسى؛ بعسا. }
\end{aligned}
$$

[10] Adl S. The tile of the Jame Damghan Mosque (about $1058 \mathrm{AC}$ ) is the oldest surviving example of the use of the tile in the Islamic architecture of Iran. Asar 1982; 3(7,7,9): 297-302. [In Persian]

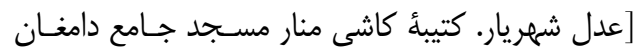

(حدود • هو ه.ق.) كهن

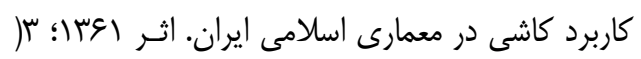

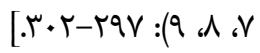

[11] Hill D, Grabar O. Islamic Architecture and Its Decoration AD 800-1500: A Photographic Survey. Faber; 1967.

[12] Carboni S, Masuya T. Persian tiles. Metropolitan Museum of Art; 1993.

[13] Pope AU, Ackerman P, Besterman T. A survey of Persian art from prehistoric times to the present: Arthur Upham Pope, editor; Phillis Ackerman, assistant editor. vol. 6. Oxford University Press; 1964.

[14] Godard A, Godard Y, Siroux M. Athar-e Iran. (Translated by Sarv-Moghadam A.). Mashhad: Islamic Research Foundation Astan Quds Razavi; 1992. [In Persian] [خدار آندره، گدار يدا؛ سيرو ماكسيه. آثار ايران. (ترجمه:

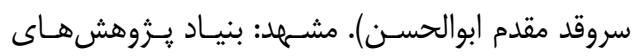
اسلامى آستان قدس رضوى؛ لوسا.

[15] Motaghedi K. Khandan e Taher e Kashani. Tehran: Peykare; 2014. [In Persian]

[معتقدى كيانوش. خاندان طاهر كاشانى. تهران: ييكره؛

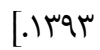

[16] Qouchani A. Persian Poems in Takhte Soleyman Tiles. Tehran: Academic Publishing Center; 1992. [In Persian]

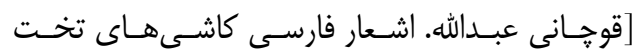

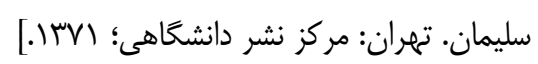

[17] Godard A, Godard Y, Siroux M. Athar-eIran. Transl. by Abolhasan Sarvghad Moghadam. Astan-e-quds-Razavi, Mashhad: Astan-e-quds-Razavi; 1992.

[18] Oghabi M. Encyclopedia of Islamic monuments - monuments of the tomb. Tehran: Islamic Art and Culture Research Center; 1999. [In Persian]

$$
\begin{aligned}
& \text { [عقابى محمد مهدى. دايـرهالمعـارف بناهـاى تـاريخى }
\end{aligned}
$$

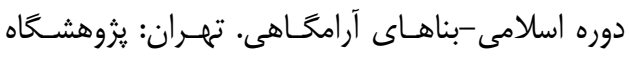

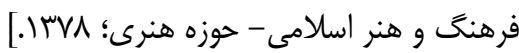

[19] Hamzavi Y, Aslani H. Architectural Decorations of Pir-Bakran Mausoleum. Isfahan: Goldasteh; 2012. [In Persian]

$$
\begin{aligned}
& \text { ] حمزوى ياسر، اصلانى حسام. آريههاى معمـارى بقعـــ }
\end{aligned}
$$

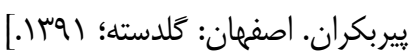

[20] Mason RB, Tite MS, Paynter S, Salter C. Advances in Polychrome Ceramics in the Islamic World of the 12th Century AD. Archaeometry 2001;43:191-209. doi:10.1111/1475-4754.00014.

[21] Mason R, Tite M. The Beginnings of Islamic Stonepaste Technology*. Archaeometry 1994;36:77-91. doi:10.1111/j.1475-4754.1994.tb01066.x.

[22] Bernsted A-MK. Early Islamic pottery: materials and techniques. 2003.

[23] Tite MS, Wolf S, Mason RB. The technological development of stonepaste ceramics from the Islamic Middle East. J Archaeol Sci 2011;38:570-80.

[24] Tite MS. The Technology of Glazed Islamic Ceramics using Data Collected By the Late Alexander Kaczmarczyk. Archaeometry 2011;53:329-39. doi:10.1111/j.1475-4754.2010.00546.x.

[25] Young S. An analysis of Chinese blueand-white. Orient Art 1956;2:43-7.

[26] Banks M, Merrick J. Further Analysis of Chinese Blue-And-White. Archaeometry 1967;10:101. doi:10.1111/j.14754754.1967.tb00620.x.

[27] Glascock MD, Popelka-Filcoff RS, Speakman RJ. Archaeological chemistry: analytical techniques and archaeological interpretation. American Chemical Society; 2007.

[28] Mason RB. Shine like the sun: LustrePainted and Associated Pottery from the Medieval Middle east. vol. 12. Mazda Pub; 2004. 
[29] Koss K, McCarthy B, Chase ES, Smith D. Analysis of Persian painted minai ware. Sci. Res. Hist. Asian Ceram. Proc. Fourth Forbes Symp. Free. Gall. Art, Archetype London; 2009, p. 33-47.

[30] Schorsch D, Manuels M. The Sherman Fairchild center for Objects Conservation, the Metropolitan Museum of Art. Treat Res Notes 2001;3.

[31] Wen R, Pollard AM. The Pigments Applied to Islamic Minai Wares and the Correlation with Chinese Blue-and-White Porcelain. Archaeometry 2016;58:1-16. doi:10.1111/arcm.12143.

[32] Tite M. Iznik Pottery: An Investigation of the Methods of Production. Archaeometry 1989;31:115-32. doi:10.1111/j.1475-4754.1989.tb01008.x.

[33] Paynter S, Okyar F, Wolf S, Tite MS. The production technology of Iznik potterya reassessment*. Archaeometry 2004;46:421-37. doi:10.1111/j.14754754.2004.00166.x.

[34] Kingery WD, Vandiver PB. Ceramic masterpieces: art, structure, technology. 1986.

[35] Pérez-Arantegui J, Molera J, Larrea A, Pradell T, Vendrell-Saz M, Borgia I, et al. Luster pottery from the thirteenth century to the sixteenth century: a nanostructured thin metallic film. J Am Ceram Soc 2001;84:442-6.

[36] Kreibig U, Vollmer M. Optical properties of metal clusters. vol. 25. Springer Science \& Business Media; 2013.

[37] Pradell T, Molera J, Smith AD, ClimentFont A, Tite MS. Technology of Islamic lustre. J Cult Herit 2008;9:e123-8.

[38] Smith AD, Pradell T, Molera J, Vendrell M, Marcus MA, Pantos E. MicroEXAFS study into the oxidation states of copper coloured Hispano-Moresque lustre decorations. J. Phys. IV, vol. 104, EDP sciences; 2003, p. 519-22.

[39] Molera J, Mesquida M, Pérez-Arantegui J, Pradell T, Vendrell M. Lustre Recipes from A Medieval Workshop in Paterna. Archaeometry 2001;43:455-60. doi:10.1111/1475-4754.00028.

[40] Padovani S, Borgia I, Brunetti B, Sgamellotti A, Giulivi A, d'Acapito F, et al. Silver and copper nanoclusters in the lustre decoration of Italian Renaissance pottery: an EXAFS study. Appl Phys A
2004;79:229-33.

[41] Pradell T, Molera J, Smith AD, Tite MS. Early Islamic lustre from Egypt, Syria and Iran (10th to 13th century AD). J Archaeol Sci 2008;35:2649-62.

[42] Ahmadi H, Salehi kakhki A, Abed Esfahani A. Relationship Between Color and Metallic Shine With the Size of Metal Nanoparticles in Luster Decorations. J Color Sci Technol 2017;1: 67-77. [In Persian]

$$
\begin{aligned}
& \text { [احمدى حسين، صالحى كاخكى احمد، عابد اصـفهانى }
\end{aligned}
$$

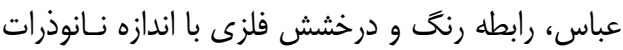

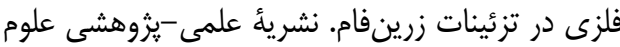

$$
\begin{aligned}
& \text { و فناورى رنغ، عوسا؛ ]1: }
\end{aligned}
$$

[43] Mehrabi Kermani S. Tazkara al-Awlia or Mazarat e Kerman. Kerman: Center for Kermanology; 2004. [In Persian] [محرابى كرمانى سعيد. تذكره الاوليا يا مزارات كرمان.

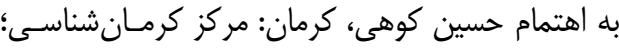

$[.1 \mathrm{M}$ r

[44] Meshkati N. List of historical monuments and ancient sites of Iran. Tehran: National Organization of Conservation of ancient objects in Iran; 1970. [In Persian]

[مشكوتى نصرتالله. فهرست بناهاى تاريخى و امـاكن باستانى ايران. تهران: سازمان ملى حفاظت آثار باستانى

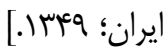

[45] Poursfar S. A review of the decoration of the tomb of Khwaja Atabak. Kerman: Kermanshenasi; 2007. [In Persian]

] يورصفر شهرزاد. بررسى تزئينات مقبرء خواجه اتابــ.

$$
\text { كرمان: كرمانشناسى؛ عربrا. }
$$

[46] Hatam G. Islamic architecture of Iran during the Seljuk period. Tehran: Jahad e Daneshgahi; 2000. [In Persian]

$$
\begin{aligned}
& \text { [حــاتم غلامعلـى معمــارى اسـلامى ايــران در دورة } \\
& \text { سلجوقيان. تهران: جهاد دانشگاهى؛ }
\end{aligned}
$$

[47] Rousta J. Examination of the position of Khaje Atabak Aladdin and Atabak Qotb al-Din Muhammad in Kerman, past and present. Iran Stud 2017;31:81-100. [In Persian]

$$
\begin{aligned}
& \text { ]روستا جمشيد. واكاوى جايگاه خواجه اتابك علاءالدين }
\end{aligned}
$$

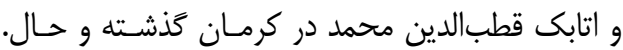

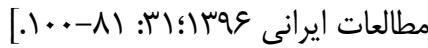

[48] Waziri A. Date of Kerman. Tehran: Elmi; 
1991. [In Persian]

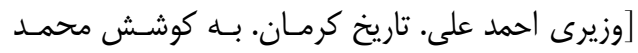

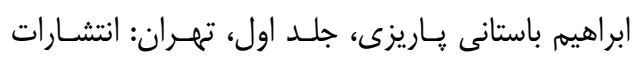

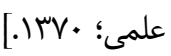

[49] Abu Hamed Kermani A. Ahd al-Ala Lemoquf al-Ala. Tehran: Ruzbehan Publication; 1977. [In Persian]

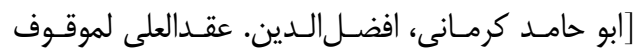

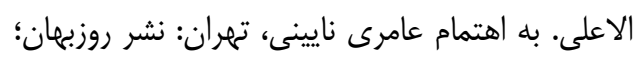

[.rote

[50] Ibn Asir EA. Al kamel: Tarikh e Bozorge Islam va Iran. (Translated by Halat A.). vol. 21. Iranian Books; n.d. [In Persian]

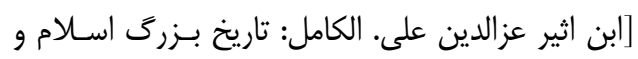

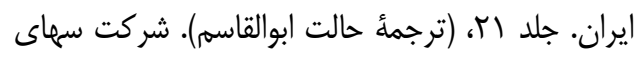
كتب ايران؛ بـ جنا.

[51] Khabisi Hosseini M. Seljuk and Ghoz in Kerman. Tehran: Tahuri Bookstore Publishing; 1964. [In Persian]

]خبيصى حسـينى محمــابراهيه. سـلجوقيان و غـز در .

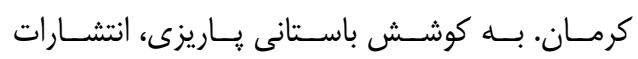

كتابفروشى طهورى؛ سعسا.

[52] Mousavi Haji R, Baho M, Shahsavari M. A structure in its political and social context: the tomb of Khwaja Atabak: constructor and construction date. Iran Stud 2008;13: 229-46. [In Persian]

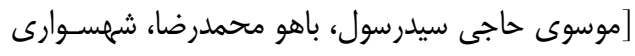

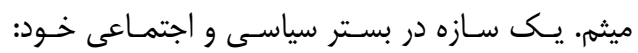
آرامعاه خواجه اتابك: سازنده و تاريخ ساخت. مطالعـات

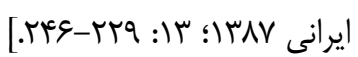

[53] Javadi Sh. The appearance of color in the outer decorations of the building: A review of the tomb of Khwaja Atabak from the oldest examples of the Negin tile in Iran. Modarres e Honar 2003;1. [In Persian]

] جوادى شهره. ظهـور رنـع در تزيينـات خـارجى بنـا:

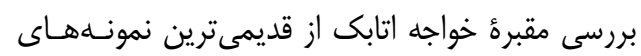

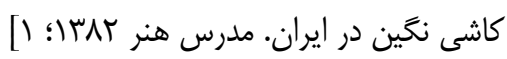

[54] Archive of Improvement and Modernization Organization of Kerman. 2006. [In Persian]

[آرشيو سازمان بهسازى و نو سازى شهر كرمان. مقبره

خواجه اتابك كرمان. فيرا.]

[55] Agha-Aligol D, Jafarzadeh M, Moradi M. Micro-PIXE: A Powerful Technique in Measurement and Determination of Raw Materials of Glass Artifacts of Parthian Period From Shaur(Susa). J Res Archaeom 2018;4(1):47-65. [In Persian]

[آقا على گَل داود، جعفرىزاده مسله، مـرادى محمـود.

ميكروييكسى: روشى توانمند در بررسى و تعيـين مـواد

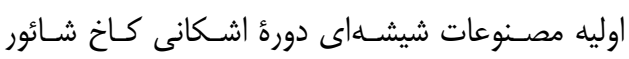

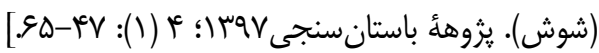

[56] Rezayi Farimani Z, Mousavi Kuhpar M. An Investigation of Glassmaking Industry at Tal-I Malyan Based on PIXE analysis. J Res Archaeom 2017;3(1):4763. [In Persian]

$$
\begin{aligned}
& \text { ]رضايى فريمانى زهرا، موسـوى كـوهير سـيد مهـدى. }
\end{aligned}
$$

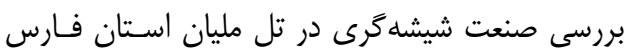

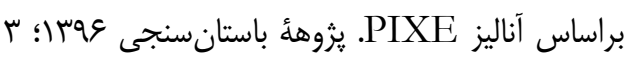

$$
\begin{aligned}
& {[\text { gr-pV:(1) }}
\end{aligned}
$$

